\title{
The International Context of the Central European Countries Participation in The Afghan Stabilization Mission
}

\author{
Bartosz Kaluga \\ West Virginia University
}

Follow this and additional works at: https://researchrepository.wvu.edu/etd

\section{Recommended Citation}

Kaluga, Bartosz, "The International Context of the Central European Countries Participation in The Afghan Stabilization Mission" (2011). Graduate Theses, Dissertations, and Problem Reports. 4737.

https://researchrepository.wvu.edu/etd/4737

This Thesis is protected by copyright and/or related rights. It has been brought to you by the The Research Repository @ WVU with permission from the rights-holder(s). You are free to use this Thesis in any way that is permitted by the copyright and related rights legislation that applies to your use. For other uses you must obtain permission from the rights-holder(s) directly, unless additional rights are indicated by a Creative Commons license in the record and/ or on the work itself. This Thesis has been accepted for inclusion in WVU Graduate Theses, Dissertations, and Problem Reports collection by an authorized administrator of The Research Repository @ WVU. For more information, please contact researchrepository@mail.wvu.edu. 


\title{
The International Context of the Central European Countries Participation in The Afghan Stabilization Mission
}

\author{
Bartosz Kaluga
}

Thesis submitted to the Eberly College of Arts and Sciences at West Virginia University in partial fulfillment of the requirements for the degree of

Master of Arts in History

Robert Blobaum, Ph.D., Chair

James Siekmeier, Ph.D.

Elizabeth Fones-Wolf, Ph.D.

Department of History

Morgantown, West Virginia

2011

Keywords: International Relations ; East-Central Europe ; Afghanistan ; NATO ; European Union 


\section{ABSTRACT \\ The International Context of Central European Countries Participation \\ in the Afghan Stabilization Mission \\ Bartosz Kaluga}

The Afghan stabilization mission is a new challenge for Central European countries in the XXI century, and probably the most important and the most difficult mission for Central European armed forces. The fundamental role of NATO in Central European countries' security results from basic strategic documents related to common defense. Strengthening NATO, in short, strengthens Central European countries' security. In addition, the Afghanistan mission provides an invaluable experience for Central European armed forces.

The findings of this study shows that although the Visegrad countries' troop contribution lagged in the early phase of the ISAF mission, with the passing of time they have shared fairly the burden of responsibilities in Afghanistan. Moreover, Visegrad countries did not deploy forces to Afghanistan only because of allied obligations but also because of national interest and pragmatic reasons. Such considerable contributions by the Visegrad countries come from their aspiration to authenticate their reputation as a reliable allies. However, this research indicates that Visegrad countries' investment of troops and money did not translate into change of relations with the USA in particularly sensitive areas, as expected by Central European governments.

The new generation of Central European citizens and politicians do not seem to be anti-American, but there is a growing sense that Visegrad countries, especially the largest member - Poland, went too far in supporting Washington's foreign policy. The major reason for the reassessment of the Polish - American relationship is Warsaw's heightened self-reliance as a member of the European Union, and awareness that now the most pivotal issues are negotiated in Brussels. Another explanation is that Warsaw is mindful that being one of the most devoted US allies in Europe has brought more disadvantages than advantages. Therefore, it seems that Americans should slowly get used to the inevitable day when Poland and other Central European countries will oppose Washington's political, economic or military projects. And it will not be associated to Central European resentment towards Washington's foreign policy, but a sign of the times of independence and maturity of the Visegrad countries in international politics. 
I have written the work independently. All works of other scholars, their principled positions, and data from written sources and from elsewhere that have been used in preparing this work have been cited.

/the author's signature 


\section{Table of Contents}

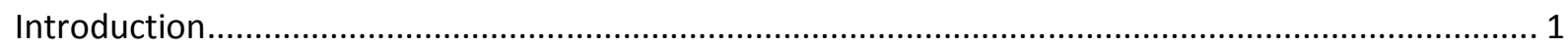

1. American Foreign Policy toward Afghanistan …....................................................................... 10

1.1. What are the Aim and Primary Tasks of the International Security Assistance Force Mission. 10

1.1.1. Stages 12

1.2. Why Things Went Wrong in Afghanistan - American Foreign Policy towards Afghanistan ...... 16

1.2.1. Bush Doctrine 16

1.2.2."Forgotten war" - Afghanistan Stabilization Mission as a Secondary Priority 23

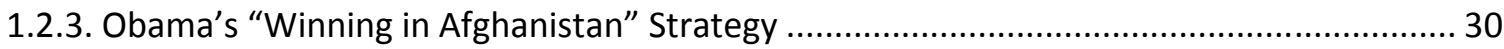

2. Central European Countries' Engagement in the Afghan Stabilization Mission. ............................... 33

2.1. Where Have You Come From and What Do You Want ? Interests Analysis ............................. 34

2.1.1. Security Conditions of the Central European Region in the XXI century ............................. 35

2.2. Central European Countries contribution to the ISAF mission and their primary tasks ............ 40

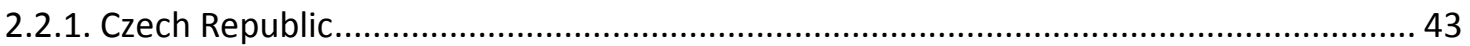



2.2.3. Poland

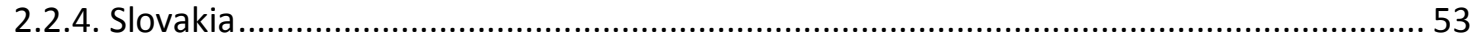

3. Experiences from the Afghan Mission - How CEC are Perceived by NATO and the USA and What



3.1. The Evaluation of the CEC commitment by NATO and USA................................................ 58

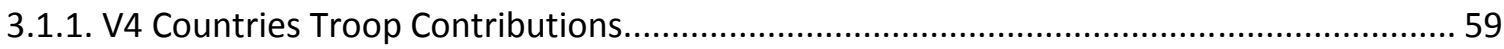

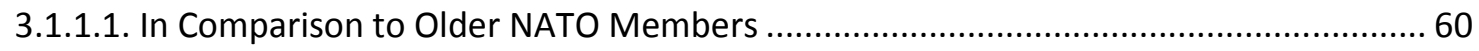

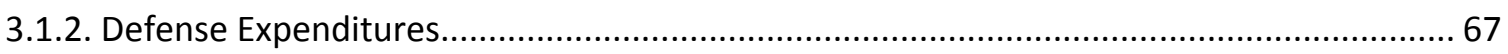

3.1.2.1. The Costs of Humanitarian and Reconstruction Effort ............................................. 72

3.1.3. Effectiveness of Engagement in Stabilization Tasks and Combat Operations .................... 75



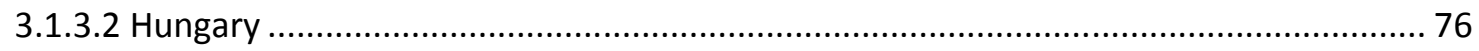


3.1.3.4. Slovakia 80

3.2. The Evaluation of the Mission in Home Countries - Advantages and Disadvantages of Participation in the Mission.

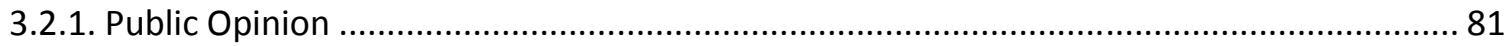



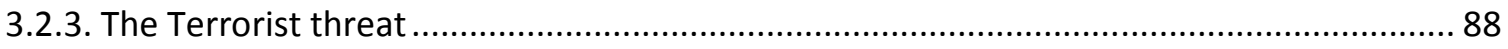

3.3. The New Shape of the American - Central European "Special Relationship" .......................... 91

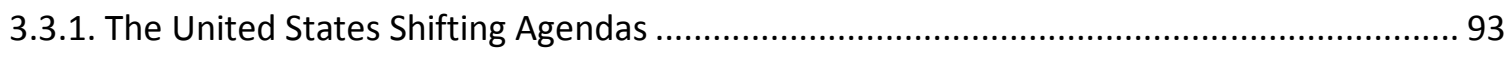

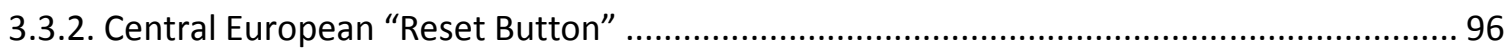

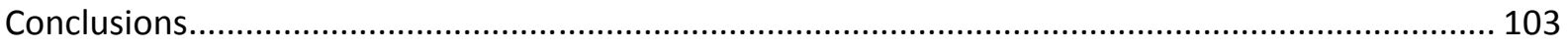

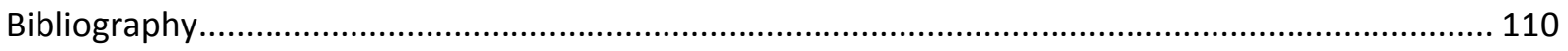




\section{Introduction}

In our globalized world there are some events which unite all people no matter what they believe. The September 11 was one of these days when probably hundreds of millions people around the world felt like Americans. In any case for current American generations beyond a doubt the terrorist attacks of 9/11 became a "day of infamy". In a similar way like the attack on Pearl Harbor in 1941, it was a day that all Americans will remember what they did and where they were when they heard about the events of that September day. If I could retrace in my mind the sequence of events that day, I would be able to reconstruct what I did exactly on 9/11 2001, though perhaps not at the very moment when American Airlines flights 11 crashed into the north tower of the World Trade Center or when American Airlines Flight 77 crashed into the Pentagon. Nevertheless, I will not probably exaggerate if I say that the September 11 was the event which for the first time in my life forced me to reflect deeply on the worldwide political implications, not only for the United States but also for Europe and my home country of Poland - a recent member of the North Atlantic Treaty Organization.

I was born in the late 1980s, too late to experience personally the epic struggle of Solidarity for freedom in Poland and latter the Soviet bloc collapse. The 1999 Central European Countries' accession to NATO fundamentally changed regional security, but it had not influenced my personal consciousness in comparison with the approaching European Union extension to the East in 2004. Thus, up until as late as the September 11, 2001 I had never experienced any event which raised my political awareness and made me aware of international importance and context as did the terrorists attacks of that day. September 11 automatically acquired a symbolic meaning. From an analytical point of view to some scholars this date determined a new age in international relations; meanwhile others acknowledged it as the first act in a global civil war. ${ }^{2}$ Indeed, the terrorist attacks on the United States - until that time recognized as a country unbeatable and untouchable at least on home ground - shocked the world and shattered the global order on the verge of new century. ${ }^{3}$ Soon the

\footnotetext{
${ }^{1}$ James M. McCormick, American Foreign Policy and Process. Fourth Edition (lowa State University: Thomson Wadsworth, 2005), 213.

${ }^{2}$ Roman Kuźniar, Polityka i Siła. Studia Strategiczne - Zarys Problematyki (Warszawa: Wydawnictwo Naukowe Scholar, 2005), 280.

${ }^{3}$ In this sense, especially for the US, the events of September 11 have had a more profound effect on theoretical and policy approaches to foreign affairs than other previous spectacular event (for example Pearl
} 
debate on worldwide terrorism engulfed western security experts, who acknowledged this watershed phenomenon as the most serious threat to international security in contemporary times. ${ }^{4}$

In addition to worldwide terrorism, several features of the present era present a greater risk to global security than in recent decades. The most important tendency of the contemporary world is the steadily growing correlation between countries and regions in all pivotal aspects of life - a phenomenon which occurring in one region finds direct or indirect resonance in other parts of the world. It is a fact that technological progress in the communication and transportation field allows for the fast and relatively easy flow of information, capital, goods and people. Moreover we can observe enormous transformation in the development of weapons of mass destruction. The threat of proliferation of nuclear weapons has become more real as a consequence. Accessibility to modern weaponry is not only available to countries with rational political systems, but also to those whose actions are unpredictable and difficult to control. Additionally, these countries are located in crucial world strategic regions. And finally, terrorist organizations which can take control of weak states although some of them use terrorists for own purposes - can obtain easier accessibility to the above-mentioned means of mass destruction and portable nuclear fuses as well. All of these factors describe the character of contemporary threats to humankind. ${ }^{5}$

Another important aspect of the contemporary world order is the fact that any single country, regardless of its size or wealth, is unable to manage independently the problems mentioned above. In the same way, no worldwide system constructed on the pattern of the national-state, will be able to manage issues with the roots springing from the present degree of globalization or the difficulties caused by this incompatibility. Constant and intensive cooperation of countries and supranational institutions is desired to undertake such tasks. Global order, in all mentioned above fields, has become a global public good: if its "production" and "supply" are provided everybody gains,

Harbor, the Vietnam War, or the fall of the Berlin Wall). Indeed, the subplots of $9 / 11$ have been clearly evidenced in American society's attitudes toward foreign affairs, increased support within Congress for foreign policy initiatives and the altered type of the presidency itself - which will be examined in the first chapter. See also: James M. McCormick, American Foreign Policy and Process, 214.

${ }^{4}$ Roman Kuźniar. Polityka i Siła, 280.

${ }^{5}$ Antoni Z. Kamiński, ed., Polityka Bez Strategii. Bezpieczeństwo Europy Środkowo-Wschodniej i Polski w Perspektywie Ładu Globalnego (Warszawa: Instytut Studiów Politycznych Polskiej Akademii Nauk, 2008), 34. 
irrespective of incurred expenditures; if it is not like that - everyone will by necessity lose. ${ }^{6}$ The perfect example is the case of the Afghan war, where American difficulties to bring the situation under control compel United States to give the operation a multilateral framework.

The Afghan War was related to the tragic events of September 2001, which had forced the United States to launch the operation Enduring Freedom and to form the international antiterrorist coalition aiming to overthrow the Taliban regime while simultaneously lifting the protective umbrella created by the Afghan state for international terrorist organizations - headed by Al-Qaeda. The defeat of the Taliban regime, from the beginning highly deceptive, allowed the international community to undertake the reconstruction and rebuilding of an Afghan state, carried out mainly by International Security Assistance Force (ISAF). Operation ISAF, basically the fundamental subject of this thesis, was initiated at the end of 2001 and the beginning of 2002. As a part of this operation, member countries mainly undertake stabilization tasks designed to support Afghan authorities in rebuilding state-run institutions, armed forces and police, and the expansion of central state authority over the whole Afghan territory. In the beginning the operation was commanded by individual countries, starting with Great Britain (ISAF-I) and Turkey (ISAF-II), followed by the joint command of Germany and Holland (ISAF-III). On the strength of the NATO Council decision of April 16, 2004 command of the ISAF operation was taken over by the North Atlantic Treaty Organization. The activities of the USA and NATO's operations have been coordinated with visible efforts to merge them further. The growing importance of stabilization activities as a part of ISAF results from demands coming from the Enduring Freedom operation. ${ }^{7}$ Similarly, along with the growing importance of the multinational operations and stabilization tasks, the demands placed on participating members have grown in parallel fashion.

Ten years after the terrorists attacks on the United States thousands of publications have appeared in direct reference to the $9 / 11$ terrorist attacks themselves and thousands more about the implications of this landmark event for the global order, internal and foreign policy approaches, as well as political outcomes for individual states. Focusing particularly on the issue of the Afghan war and latter stabilization mission, the majority of scholars have concentrated on the role of the United States - its counterterrorism operations and rooting out Al-Qaeda and the Taliban - and on NATO's

\footnotetext{
${ }^{6}$ Antoni Z. Kamiński, Polityka Bez Strategii, 41.

${ }^{7}$ Bogusław Winid, Udział Polski w Działaniach Stabilizacyjnych (Warszawa: Polski Instytut Spraw Międzynarodowych, Polski Przegląd Dyplomatyczny, nr 1 (35), 15 stycznia 2007), 5-6.
} 
mission, attentive to its peacekeeping operations and reconstruction tasks. Probing more deeply into the scope of research in that field, we can find papers analyzing the tangled web of Afghan historical circumstances (which have had an impact on failed American attempts to established a safe and democratic Afghanistan), highlighting the problems of making common USA-NATO strategy for winning in Afghanistan, or emphasizing the role of particular countries. Nevertheless, however widely scholars have analyzed the issue of the Afghan stabilization mission and whatever approach they took in doing so, the nature and context of Central European countries' commitment to this mission is one major gap in the literature. Thus, the point of departure of my research will be the examination of the Afghan stabilization mission from a different and neglected perspective, one that places the emphasis on the international context of the Afghan stabilization mission and the role of the Central European Countries within that context. Furthermore, I will also examine what has changed through the first decade of the XXI century in the special relationship between the United States and Central European countries as a result.

Central Europe is a part of the global order, but its role in the international system is no more than secondary. Even the term "Central Europe" or "East-Central Europe" creates reservations among both scholars and non-scholars. ${ }^{8}$ The term "Central Europe" first appeared during the Enlightenment

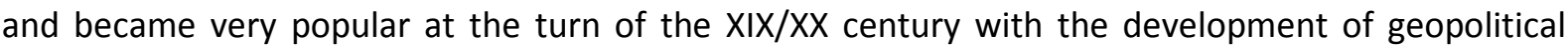
ideas and the political-economic expansionist agendas of German-speaking imperial elites. ${ }^{9}$ Central Europe or East-Central Europe can be examined from several perspectives but neither term implies homogeneous integrity. Various authors have proposed disparate classifications of the constituent countries. Depending on the criteria used, East-Central Europe consists from four (Visegrad Group: Czech Republic, Slovakia, Poland, Hungary) to seventeen countries. ${ }^{10}$ Nevertheless, there is no precise definition of Central-Eastern Europe; all are arbitrary, and it is not my aim to explore that subject at greater depth. ${ }^{11}$ Thus for my purposes, I will focus only on these countries which are contained in every classification - the Visegrad Group countries (V4). I chose to examine these

\footnotetext{
${ }^{8}$ Antoni Z. Kamiński, Polityka Bez Strategii, 7.

${ }^{9}$ It is worth stressing that in German version this term articulated political-economy imperial aspirations, meanwhile Habsburg interpretation concerned mainly cultural uniqueness of Austro-Hungarian Empire, characterized by mosaic of ethnic groups and religious dominations. In: Antoni Z. Kamiński, Polityka Bez Strategii, 15.

${ }^{10}$ Ibid., 17.

${ }^{11}$ Ibid., 19.
} 
countries for a number of reasons. First, three of the four member countries of the V4 group were included in the first NATO enlargement (Slovakia in the third). Therefore the ISAF mission in Afghanistan has become a test of their loyalty and usefulness for the activities undertaken by NATO. Second, they have been among the most visible supporters of the United States in the Europe. As a result they are more willing to support American foreign policy approaches and it is worthwhile to examine how and why they followed the United States into Afghanistan. Third, these countries learned lessons from past experiences and their transformation success, and although they still support the United States, they step into the XXI century with a more pragmatic approach to foreign affairs and relations with the Washington. This change of attitude of Visegrad group member countries toward the Transatlantic agenda demonstrates that the ISAF mission has had a significant impact on their relations with the United States.

The beginning of the final decade of the $20^{\text {th }}$ century presented Central European countries with a new geopolitical situation (Russia's withdrawal from direct political-military dominance over the region and a change in relations with the West). The western border ceased to be a threat and became a border of opportunity, which had a geopolitical and civilizational dimensions as well. Central European countries now had the chance to make good use of this new situation. The most beneficial means to that end was to attain NATO and EU membership. This was the common area of interest which united the region. ${ }^{12}$

The Visegrad member countries, by acceding to NATO and likewise the European Union, have partly waived their traditionally acknowledged sovereignty. NATO membership makes their defense policy dependent on the North Atlantic Alliance policy as a whole, and a threat to the security of any of it members has to be treated as a threat to their own security. ${ }^{13}$ From the point of view of East-Central European region as a whole, the maintenance of the contemporary world order involves not only the lack of alternatives (considered to be chaos), but also the fact that the dawn of that order changed completely the regional political-economic situation by opening the perspective of civilizational advance. The borderland situation of East-Central Europe (between two major European countries -

\footnotetext{
${ }^{12}$ To achieve that plans came for example into existence Visegrad Group and Central European Free Trade Agreement (CEFTA). In: Antoni Z. Kamiński, Polityka Bez Strategii, 20.

${ }^{13}$ Ibid., 9.
} 
Germany and Russia), which is to say high risk of external threats, particularly sensitized East-Central European countries to the significance of maintaining the status quo. ${ }^{14}$

However, the problem is that European security and defense system effectiveness still depends on the Unites States' participation. Europe stands in the face of a fundamental dilemma concerning the relationship between the EU's Common Security and Defence Policy (CSDP) and NATO, consequently future relations between the EU and United States, as well as the future of NATO. Solving these problems depends not only on Washington's policy and those of European countries and the European Union as a whole, but as well on the sort of threats confronting the West. ${ }^{15}$ One of the greatest threats, that posed by Islamic fundamentalist forces antagonistic to Western civilization, do not constitute a majority in the world of the Islamic civilization. However, they are an active minority, well organized and, in favorable circumstances able to destabilize countries from that cultural area. Thus, this factor is seriously treated in larger analyses of world security, including the security of the Central-Eastern European region. ${ }^{16}$

The Afghan stabilization mission is a new challenge for Central European countries in the XXI century, and probably the most important and the most difficult mission for Central European armed forces. Therefore, I will examine the CEC's (Czech Republic, Hungary, Poland, Slovakia) real motives for participation in the Afghan stabilization mission. It is clear that is in the interest of Central European countries to strengthen the Alliance and participate in the constant validation of its political and military credibility. The fundamental role of NATO in Central European countries' security results from basic strategic documents related to common defense. Strengthening NATO, in short, strengthens Central European countries' security. Immediately, however, one question that suggests itself is whether in fact national interest or rather alliance obligations forced CEC governments to sent troops to the unstable and risky Afghan environment? In addition, the Afghanistan mission provides an invaluable experience for Central European armed forces. Central European perceptions of the prestige and importance of the alliance implies their active participation in international missions conducted by NATO. Central European countries cannot claim from the North Atlantic Alliance costly investments or seek to deploy its bases on their territory and at the same time say that their armies

\footnotetext{
14 Ibid., 42.

${ }^{15}$ Ibid., 31.

${ }^{16}$ Ibid., 90.
} 
and soldiers will remain in their barracks. Central European countries (especially Poland) want to be present as major actors of the stabilization mission in Afghanistan. Consequently another question arises in relation to the CEC members' active participation in the mission - whatever tasks were assigned to CEC, have they been carried out successfully? Secondly, whatever ambitious goals CEC set for itself, did they achieve any rewards for good performance? The success of the operation will confirm the credibility and strengthen the cohesiveness of the Alliance. The failure of the NATO-led ISAF mission would weaken the Alliance, and de facto, one of the pillars of Central European security. ${ }^{17}$ Not to mention that CEC's performance on Afghan soil has direct implications for their relations with the United States and the so-called special relationship between Washington and this particular area of the world.

Before proceeding, it is worth mentioning what this paper is not about. I do not seek to explain here what are the biggest obstacles to accomplishing this mission, nor do propose solutions for a new approach that will overcome these difficulties and succeed in Afghanistan. Although these issues will be explored in this paper, I designed this project to explain the complexity of V4 countries participation within the international context. Thus, this paper proceeds as follows. First, I will focus on the ISAF mission itself - its aims and tasks. Further, the first chapter explores American foreign policy toward Afghanistan and the Central European context. As I already mentioned, September 11, 2001 had a powerful impact on the American foreign policy approach. Thus, I will place an emphasis in this chapter on the "Bush Doctrine", perceived by some scholars as a considerable shift in American foreign policy, while others sees it as a continuation of policy but with more powerful tools, shaped by the 9/11 event. Having in mind current problems with the Afghan stabilization mission, my aim in this chapter is also to examine American misjudgments which led to the treatment of Afghanistan as a secondary priority. Potentially, it would have been much easier to get the situation in Afghanistan under control directly after the Taliban regime had been removed and had America's involvement in Iraq not have been so considerable. Moreover, it goes hand in hand with problems of sharing responsibility for a common strategy for winning in Afghanistan which is fundamental to an understanding of the complexity of the international context of the mission. Finally, I will try to demonstrate the difference in approaches to the Afghanistan stabilization mission between the Bush to Obama administrations and of their expectations of the CEC's contribution to the mission.

\footnotetext{
${ }^{17}$ Bogusław Winid, Udział Polski w Działaniach Stabilizacyjnych, s. 10.
} 
The second chapter examines Central European countries' engagement in the Afghan stabilization mission. The first thing which has to be explored is an answer to the essential question - why, how and when V4 countries found themselves on Afghan soil. Giving detailed analysis of the specifics of the security conditions of Central European countries, I will be able to go over the expectations of the CEC in relation to their participation in the mission. Afterwards I will focus on the V4 countries contribution to the mission - their tasks within it and how have they changed with the passing of time.

The third chapter concentrates on the experiences of V4 members in the Afghan mission. Basically, I will examine the significance of the CEC contribution to the ISAF mission in cooperation with other members of the coalition. Furthermore, I would like to look carefully what CEC have gained from their contribution to the ISAF operation and cross-examine it from two perspectives. Firstly, I will try to examine how their performance was evaluated by NATO and the USA and how they were rooted in NATO structures. Secondly, I will try to confront this data with the evaluation of their performance in their home countries, which together will allow me to state the advantages and disadvantages of their active/inactive involvement in the Afghan stabilization mission. Moreover, the final part of this chapter will be dedicated to an examination of the development of relations between the U.S. and V4 countries during the whole period of their commitment to the ISAF mission.

The closing part contains conclusions and predictions concerning the CEC participation in the mission. I will try to give an assessment of the extent to which Central European expectations have been satisfied or not. Hopefully, after giving detailed answers to all these complex research questions, I will be able to scrutinize if it is still worthwhile for V4 to remain in Afghanistan, or whether it is too great a challenge which does not compensate for their invested effort.

In Poland, in contrast of other Visegrad group members, the Afghan stabilization mission enjoys a wide range of interest and has a broad bibliography. Moreover, the Polish case had been more widely described not only in Polish literature, but also in English publications. Thus the main obstacle which I notoriously kept encountering was the lack of sources in relation to the Czech Republic, Slovakia and Hungary's participation to the ISAF mission. Another stumbling block became my lack of knowledge of Central European languages, other than Polish, which did not allow me to make use of native publications of the other Visegrad group member countries. Nevertheless, in this study, I was able to manage these disadvantages by using both traditional and internet sources. While searching 
for information on the Internet, I tried to obtain all useful data about the ISAF mission and then by selective examination of that data, provide detailed information about particular V4 member country involvement in the operation. I was able to gain access to useful articles, reports and analyses by following and searching through all available TV channels, radio programs or internet websites devoted to the Afghan conflict. American and European think tank publications were extremely helpful in finding the most important data, hypotheses or trends occurring in the body of Afghan research. The study also makes use of the data and official statistics provided and published by authorized sources, such as NATO or United States, and by Central European Countries individual government ministries and institutions, especially ministries of foreign affair or ministries of defense. 


\section{American Foreign Policy toward Afghanistan}

In this chapter, after providing the fundamental information about the ISAF mission, I will examine different approaches to the Afghanistan stabilization mission, from the Bush to Obama administrations, which are essential to understand both, the problems of stabilization mission in Afghanistan and the shift in the American - Central European special relationship. I will try to focus on four broad approaches (belief system, economic system, policy institutions, and elite decisionmaking) to explain Bush's foreign policy in general (the Bush Doctrine) and the Bush administration's approach towards Afghanistan. Finally, I will try to demonstrate the Obama administration's considerable shift in focus to emphasize the Afghan stabilization mission. I will also try to explain why Bush's foreign policy took its particular approach towards Afghanistan, then explain its outcomes and what obstacles it created for Obama's foreign policy.

\subsection{What are the Aim and Primary Tasks of the International Security Assistance Force Mission.}

Two military operations are being carried out with the aim to stabilize the Afghan state. The first one, so-called Operation Enduring Freedom, began in October 2001 in the aftermath of the terrorist attacks on the United States on 11 September. The American-led operation that deposed the Taliban regime was largely a mission with limited participation of the U.S. allies. OEF is today focused primarily on the Southeastern regions, along the Pakistani border, and its stabilization and reconstruction tasks always contained a counterinsurgency component against the Taliban and remnants of al-Qaeda. Despite the fact that NATO members took active part in that operation, OEF was not a NATO mission. ${ }^{18}$ The later NATO-lead operation, the International Security Assistance Force (ISAF), was established in the aftermath of the American invasion as a parallel operation to the OEF. ${ }^{19}$

\footnotetext{
18 John R. Hillison, New NATO Members: Security Consumers or Producers ? (United States: Strategic Studies Institute. United States Army War College, 22 April 2009), 27.

${ }^{19}$ Magdalena Trzpil, Afganistan jako Największe Współczesne Wyzwanie dla NATO (Warszawa: Biuro Bezpieczeństwa Narodowego, Bezpieczeństwo Narodowe, III-2009/11), 51.
} 
The ISAF mission was established in accordance with the Bonn Conference agreements of December 2001 (more accurately UN Security Council Resolutions 1386, 1413, and 1444). ${ }^{20}$ Afghan opposition authorities who attended the forum initiated the course of rebuilding and reconstructing their country by creating a new government architecture, that is to say the Afghan Transitional Authority (ATA). The idea of a UN-mandated international force to support a new ATA structure was additionally linked with the conception of constituting secure conditions in and around the Kabul area and help the reconstruction activities in Afghanistan. This agreement enabled the establishment of a three-way cooperation among the ATA, the UN Assistance Mission in Afghanistan (UNAMA) and ISAF. $^{21}$

While ISAF was initially led by NATO nations with six-month long successive rotations (the United Kingdom, Turkey and Germany/Netherlands), NATO did not take a command over the ISAF mission until August 11, 2003. Once the Alliance assumed command, it started executing the coordination and planning of the Force's tasks, including the equipping of an army command and headquarters on Afghan soil. This new leadership design solved the problem of a constant search seek for new countries to supervise the operation and establishing of new headquarters twice a year in a complex environment. The advantage of a sustained NATO headquarters as well paved the way for small countries, not to seize leadership responsibility, but to perform greater tasks within a multinational headquarters. ${ }^{22}$

At the beginning ISAF's mandate was restricted only to providing security in and around Kabul. However, the member countries of the Alliance, primarily at the request of the Afghan authorities, asked permission to extend ISAF responsibilities. Once NATO became responsible for the ISAF mission, it began progressively expanding its role in Afghanistan. ${ }^{23}$ This was reflected on October 2003, when the UN enlarged ISAF's responsibilities and its newly given mandate ranged across the whole of Afghanistan (UNSCR 1510). ${ }^{24}$ Thereafter, new demanding tasks were added to the

\footnotetext{
${ }^{20}$ Hillison, New NATO Members, 28.

${ }^{21}$ http://www.isaf.nato.int/history.html

22 Ibid.

${ }^{23}$ Hillison, New NATO Members, 28.

${ }^{24}$ It is worth to point out that majority of decisions of 1510 resolution certify arrangements approved within the Bonn Agreement from 2001. In: http://www.isaf.nato.int/history.html
} 
international forces' responsibilities. For example ISAF became responsible for supporting the Afghan authorities in expanding central power throughout state, carrying out reconstruction activities, and helping with the process of disarming, demobilization and disbanding of local armed groups. ISAF was also obliged to take an active part in the creation and training of both the Afghan administrative structures and security forces (police and army). ${ }^{25}$

\subsubsection{Stages}

After NATO took command over the ISAF operation, the process of seizing comprehensive responsibility over the whole Afghan territory occurred in four stages. During Stage One of ISAF (2003-2004), international forces (predominantly French and German forces) were located in the northern part of the country. ${ }^{26}$ The main principle of this mission was to provide security to the government in the capital of Kabul. The mission was also enlarged with the expansion of Provincional Reconstruction Teams (PRT). ${ }^{27}$ In December 2003, the NATO Council authorized the Supreme Allied Commander to set in motion the expansion of ISAF mission by assuming control of the German-led PRT in Kunduz. ${ }^{28}$ Thereafter, on 31 December 2003, the military part of the Kunduz PRT was detached and placed under ISAF command as mapped below and was the first step in the development of the operation. Half a year later, on 28 June 2004, at the Summit meeting of the NATO Heads of State and Government in Istanbul, the Alliance declared that it would form PRTs in Baghlan, Feyzabad, Mazar-e Sharif and Meymana, all situated in northern Afghanistan. All these civilmilitary teams were established to support enlarged governance and reconstruction activities throughout the Afghan state. The first stage was accomplished on 1 October $2004 .^{29}$

\footnotetext{
${ }^{25}$ Magdalena Trzpil, Afganistan jako, 52.

${ }^{26}$ Ibid., 53.

${ }^{27}$ Hillison, New NATO Members, 28.

${ }^{28}$ All remaining PRTs, eight in 2003 , stayed under the command of OEF.

${ }^{29}$ http://www.isaf.nato.int/history.html
} 


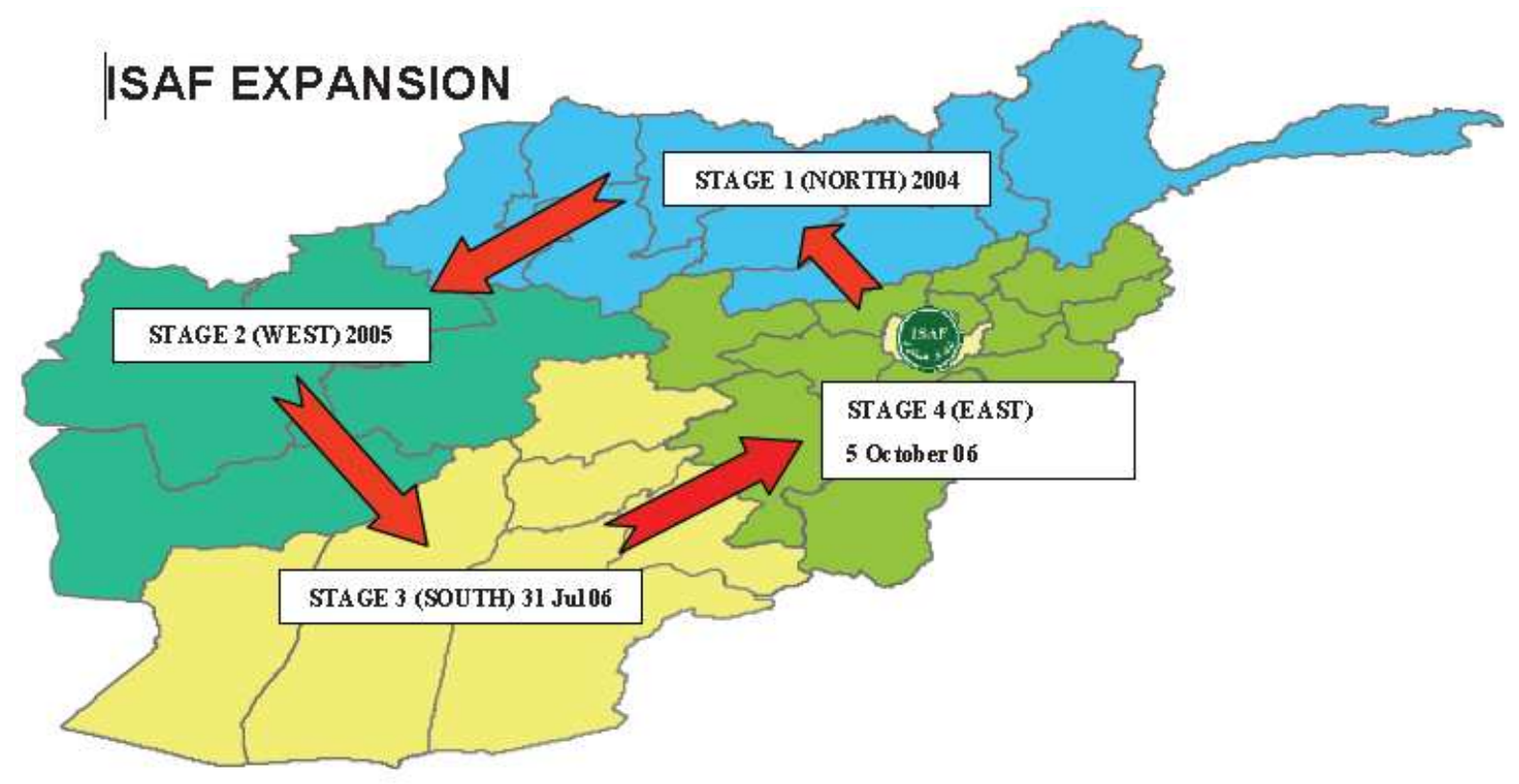

Source: http://www.isaf.nato.int/isaf-placemat-archives.html (Archive Placement valid as of 29 January 2007)

In turn, under UN SCR 1623, Stage Two involved Western territories, dominated by Italian and Spanish administrations who provided the bulk of the forces (which ended in May 2005). ${ }^{30}$ The evolution of this part of the mission began on 31 May 2006, while ISAF took responsibility for two more PRTs in the provinces of Farah and Heart, and of a logistics base in the latter. ${ }^{31}$ From September of that year, two extra ISAF-led PRTs on the western territories of Afghanistan (in Chaghcharan and Qala-e-Naw, the respective capitals of Ghor and Baghdis provinces) became operational completed ISAF's expansion westward. Following this process, the command became responsible for nine PRTs in the northern and westerns part of Afghanistan, providing security support in $50 \%$ of the country. Both of these sectors were generally peaceful when NATO took over leadership there. ${ }^{32}$ In September 2005, NATO also deployed 2,000 additional men-at-arms to Afghanistan to assist in the September parliamentary and provincial elections. ${ }^{33}$

\footnotetext{
${ }^{30}$ Hillison, New NATO Members, 28.

${ }^{31}$ Trzpil, Afghanistan jako, 53

${ }^{32}$ Hillison, New NATO Members, 28.

${ }^{33}$ http://www.isaf.nato.int/history.html
} 
Thanks to relative stability in the northwestern part of the Afghanistan, both the first and second stages, were conducted efficiently. On 8 December 2005, after a discussion at NATO Headquarters, the Allied foreign ministers authorized a strategy of expanding the international forces' role and appearance in Afghanistan. The first part of this strategy was to expand to the south in 2006, what basically meant moving into the next stage. Starting in July 31, 2006, ISAF took control over the southern territories of Afghanistan from American-led coalition forces, which expanded its area of mission to an additional six provinces (Day Kundi, Helmand, Kandahar, Nimroz, Uruzgan and Zabul) and its command of other PRTs - now total of 13 PRTs under ISAF control, around three-quarters of the country's territory. ${ }^{34}$ However, we have to bear in mind that the realization of the third stage, which assumed an improvement of the security situation in the southeastern region, became several times postponed on the account of rebel activity. Southern Afghanistan was an area with serious Taliban rebel activity and therefore a crucial place of OEF operations. ${ }^{35}$ As a consequence the manpower of ISAF increased significantly, from about 10,000 troops to 20,000 . Ultimately these territories were seized in August 2006 - first and foremost British, Danish, Dutch and American contingents represented the largest contingents of the NATO force located in the most perilous part of the country. ${ }^{36}$ While stage three of the ISAF mission had begun, the divergence of views among allies became more noticeable. NATO members mostly agreed on the operation, but they disagreed on the strategy how to achieve the planned goals. Many of the NATO members established national caveats on where and when their troops could be used. These restrictions largely restrained military effectiveness and generated substantial strain with the Alliance. ${ }^{37}$

Finally Stage Four, which started in October 2006, implemented the final stage of NATO's effort to take over responsibility for consolidation of the entire country from the US-led coalition. ${ }^{38}$ Over and above increasing NATO's area of mission, the modified operational strategy also set the scene for increased ISAF tasks in Afghanistan, including the stationing of ISAF Operational Mentor and Liaison Teams (OMLT) to Afghan National Army (ANA) forces at various level of leadership. ${ }^{39}$

\footnotetext{
${ }^{34}$ Ibid.

${ }^{35}$ Hillison, New NATO Members, 28.

${ }^{36}$ Trzpil, Afghanistan jako, 53.

${ }^{37}$ Hillison, New NATO Members, 28.

${ }^{38}$ Trzpil, Afghanistan jako, 53

${ }^{39}$ http://www.isaf.nato.int/history.html
} 
Conceiving NATO's engagement in the Afghan stabilization mission had to be determined in the terms of the time length of the particular phases. From the outset, NATO planned five phases for the ISAF operation in Afghanistan. The first phase, described as the phase of assessment and preparation, was devoted to the actions conducted in Kabul and its area. The second, the expansion of the ISAF's mandate over the whole Afghan territory, was finished in $2006 .{ }^{40}$ The three remaining phases are devoted to the stabilization, transition and redeployment processes. While since 2009 ISAF has operated in the third phase, NATO leaders began discussing when they should enter to the next to last phase - the "transition" and hand over security responsibility to the Afghan National Security Forces (ANSF). However, some NATO officials are concerned that entering into the "transition" phase could lead troop-contributing countries to enter phase five, the last "redeployment" phase. ${ }^{41}$ That was announced at the Lisbon NATO Summit in November 2010 - at which point the Alliance started entering a new phase of its mission in Afghanistan. Since 2011 NATO has progressively transferred the responsibility for security situation to the Afghans, aiming to complete this process by the end of 2014 . The transition process will be "conditions-based, not calendar-driven and will not equate to the withdrawal of ISAF troops". NATO also announced a longterm partnership with Afghanistan beyond the given date of the 2014 withdrawal. It is worth pointing out that entering the last phase was not motivated by an objective evaluation of the security situation in the Afghanistan, but rather by public support in allied countries which plummeted, especially in relation to the combat role of deployed contingents. ${ }^{42}$

\footnotetext{
${ }^{40}$ Trzpil, Afghanistan jako, 54.

${ }^{41}$ Vincent Morelli and Paul Belkin. NATO in Afghanistan: A Test of the Transatlantic Alliance (Washington: Congressional Research Institute, 3 December 2009), 13.

${ }^{42}$ Garreth Chappel, What Future for 'Out-Of-Area' Operations after Afghanistan ? (Warsaw: The Polish Institute of International Affairs. Policy Paper, no. 4, March 2011), 2.
} 


\subsection{Why Things Went Wrong in Afghanistan - American Foreign Policy towards Afghanistan}

An explanation of American policy towards Afghanistan is essential for understanding the major obstacles which harmed the effective conduct of the operation. The plan for international forces was to take responsibility over the entire nation, thereby providing conditions for Americans to shrink their commitment. The NATO-led ISAF mission in Afghanistan has encountered several major challenges that undermine its capabilities to accomplish the operation. The mission took on a whole a new dimension with the Taliban resurgence in southern and eastern Afghanistan in 2006. Therefore, this thesis will start with an explanation of perhaps the most important ingredient of initial failure of the mission and later Taliban resurgence, the insufficient American involvement in Afghanistan after the rout of the Taliban. The U.S. mission has gradually converted to a nationbuilding operation, but the initial small American force engagement led the Taliban's hard-core leadership to escape into Pakistan's Federally Administrated Tribal Areas (FATA) and created further problems of accomplishing the mission. ${ }^{43}$

\subsubsection{Bush Doctrine}

Before 9/11, only a few Americans and non-Americans had foreseen George W. Bush conducting such a challenging, powerfully built, pro-active and engaged American foreign policy, probably even Bush himself. According to Robert Singh, Bush in his presidential campaign rejected everything what was at the core of the Clinton administration - "humanitarian interventions, peace-keeping missions and 'nation-building' efforts abroad, favoring instead a coolly calculated appraisal of America's vital national interests. ${ }^{\prime 44}$ According to Mackubin Owens, at the beginning, Bush's administration had not adopted a foreign policy approach focused on terrorism and the proliferation of Weapons of Mass Destruction, the core of what became Bush Doctrine. Nor had he focused on Iraq or Afghanistan although, Iraq occupied a key item of concern in terms of U.S. foreign policy toward the Middle East. Relations with great powers, such as Russia and China, were the centre of activity. Everything

\footnotetext{
${ }^{43}$ Douglas V. Mastriano, Faust and the Padshah Sphinx: Reshaping the NATO Alliance to Win in Afghanistan (Carlisle Barracks: US Army War College, 2010), 6-7.

${ }^{44}$ Robert Singh, "The Bush Doctrine," in The Bush Doctrine and the War on Terrorism: Global Responses, Global Consequences, ed. Mary Buckley and Robert Singh (London, New York: Routledge, 2006), 14.
} 
changed with the terrorist attacks and Bush abandoned "realism" and transformed his approach to a more revolutionary style of the foreign policy. ${ }^{45}$

Soon after the terrorist attacks, George W. Bush gave a speech addressed to a joint session of Congress on September 20, 2001. ${ }^{46}$ The "Bush Doctrine" was for the first time enunciated and repeated later in Bush's landmark speeches and public rhetoric, although it was never formally articulated. The essence of the doctrine was contained in George W. Bush's Second Inaugural Address: "It is the policy of the United States to seek and support the growth of democratic movements and institutions. In every nation and culture, with the ultimate goal of ending tyranny in our world. ${ }^{\prime \prime 7}$ According to Owens, there are three main principles upon which the Bush Doctrine is based. ${ }^{48}$ First, the dismissal of "moral equivalency" in global affairs. Second, rejection of the "social work" theory of terrorism, which more or less means that economic determinants, such as poverty and hunger, are the core of the terrorism phenomenon. ${ }^{49}$ Third, the acknowledgment that in the world after 9/11, conventional methods to deal with the threats - deterrence, containment, and ex post facto responses - are incapable at times when rogue states or terrorists could possess weapons of mass destruction. Therefore, under the Bush Doctrine, the United States implemented the right of a state to undertake preventive war, an action the violates international law and norms. We have to bear in mind that international law recognized only the right of a country to launch a preemptive strike against another, and only when the probability of an attack by the latter is looming. President Bush argued that in the era after 9/11, in a globalized world dealing with threats like calamitous terrorism and state and non-state actors acquiring or possessing weapons of mass destruction, this differentiation was no longer valid. If a strike is threatening, it could be too late simply to preempt

\footnotetext{
${ }^{45}$ Mackubin T. Owens, The Bush Doctrine: The Foreign Policy of Republican Empire (Foreign Policy Research Institute, Winter 2009), 23.

46 "We Are a Country Awakened to Danger and Called to Defend Freedom", The Text of President George W. Bush's Address to a Joint Session of Congress Concerning the Sept. 11, 2001 Terrorists Attacks on America (The Archives of Global Change in the $21^{\text {st }}$ Century) http://www.september11news.com/PresidentBushSpeech.htm

${ }^{47}$ Owens, The Bush Doctrine, 24-25.

${ }^{48}$ Robert Singh recognizes four key familiar elements of the "Bush Doctrine": "preventive war, confronting the nexus of weapons of mass destruction (WMD) and catastrophic terrorism, 'regime change' for 'rogue states' and democracy promotion" Singh, The Bush Doctrine, 12.

${ }^{49}$ According to this belief the goal of the terrorist attacks is to destroy Western liberalism.
} 
it. ${ }^{50}$ Bush's speeches were construed by wider audiences as heralding a fundamental break with America's foreign policy past.

The dominant narrative about the "Bush Doctrine" argued that the American founders based foreign policy on the criteria of non-intervention and isolationism. ${ }^{51}$ However, foreign policy based on the principle of isolationism and non-interventionism was abandoned in the XX century. Owens in his publication argues that earlier in its history the U.S. had responded unenthusiastically to threats to its own national interests. ${ }^{52}$ Accordingly, he indicates that the United States since the beginning has been attached to a foreign policy of "realism", whose main principle is that the leading factor in international affairs is national security, which can be safeguarded simply by the competent application of power relevant to other international subjects. Therefore, the conventional narrative emphasizes that "neo-conservatives" are alarmingly moralistic and idealistic in terms of foreign affairs. They strongly believe that Washington has a special role in spreading democracy and the principles of liberty. Other characteristic features to which they are committed include the preservation of American hegemony, suspicion of international institutions and approval of the unilateral use of power authorized to secure and accelerate democracy. ${ }^{53}$

Considering the Bush Doctrine as a political or grand strategic modus operandi in international affairs, it is a foreign policy closely tied with American liberal political traditions, whose principle is primacy on the basis of the intersection of hegemonic stability theory and the theory of the democratic peace. The essence of this "benevolent" primacy is a belief that U.S. power is good not only for the United States itself, but also provides benefits for rest of the world. The defense of that argument is that United States itself can enjoy a full security only when other countries in the world are also secure. ${ }^{54}$ Invoking Robert Gilpin's words, Owens notes that hegemonic stability theory maintains that a "liberal world order" does not come to being in the heat of the moment, as an outcome of some global "invisible hand". The existence of liberal institutions is not enough. To

\footnotetext{
${ }^{50}$ Owens, The Bush Doctrine, 25-26.

${ }^{51}$ The principles contained in the Washington's Farewell Address and the Monroe Doctrine.

${ }^{52}$ With the exception of Woodrow Wilson's idealistic principles of foreign policy which foreshadowed George W. Bush's utopian attempts to establish democracy in the Middle East.

${ }^{53}$ Ibid., The Bush Doctrine, 24-25.

${ }^{54}$ Ibid., 28.
} 
uphold liberal world order, Washington has to be eager and able to preserve it. He strengthens his argumentation by citing Ethan Barnaby Kapstein's opinion that such a system necessitates a "hegemonic power, a state willing and able to provide the world with collective goods of economic stability and international security". In accordance with hegemonic stability theory, without U.S. power the world would experience a less safe and peaceful global order. ${ }^{55}$ In this way, both United States after the Second World War, and Great Britain before, carried out the supremacy role in global affairs not out of altruism, but merely it was in their national interest to take it up.

Coming back to the theory of the democratic peace, it is widely assumed by liberal internationalists that at the core of the "democratic peace" idea is the assumption that liberal democracies do not fight among themselves. This theory is based on Immanuel Kant's concept, presented in Perpetual Peace, that the consequence of development of constitutional republics was peace among states. Not only President Bush made use of that idea, but also president Clinton. The latter, in his 1994 State of the Union address, said: "Ultimately, the best strategy to ensure our security and to build a durable peace is to support the advance of democracy elsewhere. Democracies don't attack each other." What is more, in 2005, Congress legislated the Advance Democracy Act (introduced by Senators John McCain and Joe Lieberman), which states: "Wars between or among democratic countries are exceedingly rare, while wars between and among nondemocratic countries are commonplace, with nearly $170,000,000$ people having lost their lives because of the policies of totalitarian governments. ${ }^{\prime \prime 56}$

Another interesting interpretation of the Bush Doctrine, in relation to the four schools of "American" foreign policy thought, can be found in Singh's publication. He claims that Charles Krauthammer in a similar vein identified the Bush Doctrine as "less one of neo-conservatism than 'democratic realism" - "metaphorically Jacksonianism and Wilsonianism had been melded into a new hybrid, one unafraid to project American power or American values - indeed, one that saw the combination as inextricably linked for the preservation of American security. In this regard, the traditional biases of foreign policy approaches were subverted. The Bush Doctrine embraced liberal idealists' faith in

\footnotetext{
${ }^{55}$ Cited as an example is the decay of Pax Britannica, which many believe contributed to the outbreak of two world wars in the first half of the twentieth century. Great Britain's vanishing hegemony led small countries which tended to cooperate with British power to direct their interests to other powers, the outcome of which was a fragmented and polarized international system. It resulted in depression and war. The decline of American supremacy could lead to the same dangerous results, it is argued. Ibid., 28.

${ }^{56}$ Ibid., 26-28.
} 
(American) values, agreeing that the form of domestic regimes bore directly on their foreign policies and that 'democratic peace' proponents had it right. But the Doctrine evinced a much more tepid faith in international law and multilateralism as promising instruments to ensure liberty's advance in the new era. Wilsonian ends were thus married and hardheaded, realist means to yield idealism without illusions". ${ }^{57}$ The combination emphatically confirmed that, under the Bush Doctrine, the US was no longer a "status quo power". ${ }^{58}$

While scholars argue over the extent of shift and the break with American foreign policy continuity, for Singh it is obvious that the terrorist attacks allowed for the development of policies which before would not have been possible at all, or at least would not have flourished in such considerable piecemeal and fitful fashion of previous conditions. ${ }^{59}$ Citing Inderjeet Parmar - "the new more aggressive foreign policy pursued by the Bush administration [was] merely made more acceptable by 9/11, not made by $9 / 11$ itself." Nevertheless, as believed by Singh, the September terrorist attacks not only assisted the progress but forced a re-evaluation of the U.S. global role as a 'reluctant sheriff'. ${ }^{60}$ Lawrence Kaplan and William Kristol in 2003 described the post 9/11 "neo-conservative" world view. They argued that during the post-Cold War era, liberals and realists had approached the global order from distinct intellectual postulates but supported a shared purpose of a "minimalist approach to foreign policy - one because the very concept of self-interest provokes discomfort, and the other because it defines the national interest far too narrowly." Instead, George W. Bush promoted a "distinctly American internationalism" and powerful foreign policy by excluding both

\footnotetext{
${ }^{57}$ Singh, The Bush Doctrine, 20.

${ }^{58}$ For a more extended discussion of four schools of "American" foreign policy thought, see Walter Russell Mead, Special Providence: American Foreign Policy and How it Changed the World, (New York: Routledge, 2002).

${ }^{59}$ Derek Chollet and James Goldgeier, America Between the Wars. From 11/9 to 9/11: The Misunderstood Years Between the Fall of the Berlin Wall and the Start of the War on Terror. (New York: Public Affairs: 2008$) 314$.

${ }^{60}$ It is hard to imagine that particular events in subsequent American foreign policy could have ever appeared. As examples, Singh cites American intervention in Afghanistan, establishing US military bases in the Central Asia, and withdrawal of American military forces from Saudi Arabia. By the same token such developments as the re-emergence of national security as the first concern for Americans, a green light for counter-terrorism priority, focus on the Middle East as the key issue of US foreign policy for the first time since the beginning of the Republic and establishing the Department of Homeland Security are the critical phenomena which emerged as the result of tragic events of 9/11. Singh, The Bush Doctrine, 14.
} 
George H. W. Bush's “narrow realism' and Clinton's "wishful liberalism". ${ }^{61}$ However, Singh argues, some policies that owe their origin to $9 / 11$ were evident long before the terrorist attacks. ${ }^{62}$ From the beginning of his presidency Bush's approach called for struggle against excessively burdensome limitations - from international laws to allies - to pursue America's security and to modify the global status quo to cope with security perils. ${ }^{63}$ Supporting this theory, according to Mackubin Owens, rather than "neo-conservative" innovation, Bush adopted an approach which kept to the tradition of American foreign policy since the Early Republic: "The Bush Doctrine represents a continuation of a policy that fuses American security and the 'American Mission.' The 'ultimate goal of ending tyranny in our world' has been a cornerstone of American foreign policy since the earliest days of the Republic." ${ }^{64}$ Indeed, the U.S. national interest has more components than simple security. Thus, the Bush Doctrine, for Owen, is the "latest manifestation" of commercial and ideological factors that have had a major influence on national security concerns. ${ }^{65}$

In summary, the Bush Doctrine, rather than being supported by experts, has become subjected to enormous criticism, both at home and in the world. According to Singh, critics of Bush Doctrine centered on three main problems of Bush Doctrine. ${ }^{66}$ First, even with commonsense argumentation, preventive war created more problems than it resolved. The Bush Doctrine undermined the legitimacy of American democratic efforts by adaptation of preemptive strike and a sense of

\footnotetext{
${ }^{61}$ Ibid., 18.

${ }^{62}$ Treaties considered pernicious to the U.S. national interest were disobeyed (the Anti-Ballistic Missile Treaty) or left to work without American participation (Kyoto, the International Criminal Court). Supranational institutions were treated with gentle arrogance (the United Nations) and received interest only when it was advantageous to US interests (the World Trade Organization, G8). The North Atlantic Organization became to an increasing extent problematical and at best a politically symbolic vehicle for the manifestation of American multilateral involvement.
}

${ }^{63}$ Singh, The Bush Doctrine, 15.

${ }^{64}$ Owens, The Bush Doctrine, 28.

${ }^{65}$ He concludes that "When it comes to the Bush Doctrine, the main issue-as is the case with foreign policy in general-is prudence, which Aristotle described as deliberating well about those things that can be other than they are (means). According to Aristotle, prudence is the virtue most characteristic of the statesman. In foreign affairs, prudence requires the statesman to adapt universal principles to particular circumstances in order to arrive at the means that are best, given existing circumstances. In fact, the Founders and the statesmen of the Early Republic were not isolationist but prudent." Ibid., 25.

${ }^{66}$ Singh, The Bush Doctrine, 21-23. 
American power which is allowed to rely on own merits (unilateralism), as well putting an emphasis on bilateral agreements, instead of seeking cooperation within multilateral institutions - for example, bilateral agreements under the Bush presidency with Central European states, which will be described in subsequent chapters ${ }^{67}$ The apprehension that some states, from Israel to China, would be able to legitimize their actions in similar fashion leads one to believe that international legal norms have been threatened - especially the unacceptability of wars not authorized by the United Nations Security Council. Furthermore, the ambiguities of judging and identifying possible imminent specific threats arose. Second, regime change raised serious questions about the limits of state sovereignty. Although the U.S. attack on Afghanistan raised only slight dissent at home or elsewhere, no broad-based or permanent international consensus had yet occurred about the circumstances under which a country could lose its sovereign status - whether because of domestic tyranny, genocide, supporting terrorism, or acquiring WMD.

Moreover, what mechanism of intervention should be applied if such a thing were to be committed ? Third, the idea of American pre-eminence was open to doubt. Critics have focused on its "arrogance", or "overstretch" and the excessive demands which could be only fulfilled by a more reasonable international balance of power. "For the majority of critics, however, the central flaw in this notion was less the basic goal than the overly narrow conception of power and the excessively limited range of instruments employed to achieve American goals." ${ }^{68}$ The gap between American foreign policy goals and the attainable resources to achieve them, if anything, has grown larger in the years since. The case of the Afghan stabilization mission especially proves that the last criticism is correct. $^{69}$

\footnotetext{
${ }^{67}$ Kamiński, Polityka Bez Strategii, 50.

${ }^{68}$ Singh, The Bush Doctrine, 21-23.

${ }^{69}$ Chollet and Goldgeier, America Between the Wars, 316.
} 


\subsection{2."Forgotten war” - Afghanistan Stabilization Mission as a Secondary Priority}

After almost nine years of war, the United States together with its NATO Allies have been unsuccessful in establishing a sustainable Afghan state. Scholars from both sides of the Atlantic argue that the American-led NATO alliance cannot demonstrate considerable achievements in terms of progress. All of the collected data since 2001 reveal that the Western coalition has failed in establishing conditions for security and state-building. The most noticeable failures are: "increased civilian and military casualties, expansion of the guerillas, unfavorable perceptions of foreign troops by the local population, absence of functioning national institutions, and growing destabilization of the Pakistani border, which threatens NATO's logistical roads, essential for resupplying NATO forces." ${ }^{70}$ Most of the experts seek the cause of these failures in the massive misjudgments of the Bush administration. Although, it would be unfair to put the blame only on the Bush administration, there are three major repeated allegations regarding the Afghan stabilization mission under Bush's leadership: prioritization of Iraqi mission at the expense of Afghanistan, lack of nation-building effort, and disagreements in finding a common strategy with European allies for winning in Afghanistan.

The chairman of the Joint Chiefs of Staff, Mike Mullen, put it bluntly in late 2007 - "In Afghanistan we do what we can. In Iraq, we do what we must" ${ }^{71}$ Long before that President Bush had declared vigorously that he "listened to his generals" and provided them with everything what they needed to succeed. This may be true, but only in the case of Iraq. Thus the country strictly associated with the 9/11 plot and war on terrorism became overshadowed by the war in Iraq. The reason for this was in part due to the initial successes against the Taliban and al-Qaeda and the loss of an ability to perceive real deepening challenges as the war wore on. At the time when the focal point of American foreign policy shifted west, toward Baghdad, a strategy for a robust reconstruction of Afghanistan melted

\footnotetext{
${ }^{70}$ Gilles Dorronsoro, Focus and Exit: An Alternative Strategy for the Afghan War (Washington D.C.: Carnegie Endowment for International Peace, January 2009), 1-2.

${ }^{71}$ David E. Sanger, The Inheritance: The World Obama Confronts and the Challenges to American Power, (New York: Harmony Books, 2009), 119.
} 
away. The war which was supposed to be an easy victory was camouflaged by the fact that the Taliban had never been defeated and they simply moved to the tribal areas in Pakistan. ${ }^{72}$

In the spring and summer of 2006 the Taliban conducted the largest offensive since the beginning of the American invasion. ${ }^{73}$ In the same year 191 American and NATO soldiers died, which was a 20percent increase over the 2005 toll, generating - statistically - the fact that it was almost as dangerous to serve in Afghanistan as in Iraq. ${ }^{74}$ The National Intelligence Estimate alerted in July 2007 that al Qaeda had reestablished "a safe haven in the Pakistan Federally Administrated Tribal Areas," and what is more, "regenerated key elements of [their] Homeland attack capability" against Americans and their allies. ${ }^{75}$ In late 2007 Gen. McNeil was already aware that things had gone bad and that NATO was facing a risk of retreat. ${ }^{76}$ When NATO forces arrived, they opened and helped to run schools, but when they left their efforts were demolished by the Taliban. In 2008 it was even worse. Such events like bombings, coordinated and uncoordinated attacks and causalities seriously increased. Afghanistan was rather a country under siege than a country with successfully implemented conditions to become a sustainable state. ${ }^{77}$ Thus, as a result, by Spring 2008 for American troops it was far more dangerous to stay in the Afghanistan theater, simply because of the fact that their casualties exceeded those in Iraq. ${ }^{78}$ At the end of Bush's presidency, rather than celebrating the triumph of democratic stability, his administration was facing the truth that Afghanistan was returning to the chaos that existed when he moved into the White House. The initial

\footnotetext{
${ }^{72}$ Sanger, Inheritance, 118.

${ }^{73}$ The Taliban took advantage of the ongoing transition of responsibilities to NATO and thus they fought against newly deployed NATO troops.

${ }^{74}$ Sanger, Inheritance, 158.

${ }^{75}$ Ibid., 116.

76 Dan Kelly McNeill (born July 23, 1946) was a four-star general in the United States Army. He served as Commander of Coalition Forces in Afghanistan from 2002 to 2003 and as Commanding General, U.S. Army Forces Command (FORSCOM) from 2004 to 2007. He then served as Commander, International Security Assistance Force (ISAF) in Afghanistan from February 1, 2007 to June 3, 2008. http://en.wikipedia.org/wiki/Dan_K._McNeill

${ }^{77}$ Sanger, Inheritance, 115-116.

${ }^{78}$ Ibid., 158.
} 
successful phase of the war proved deceptive for Bush, who was surprised that the "good" war had gone so bad - mainly because the Iraqi war had absorbed most of the American resources. ${ }^{79}$

"We are simply in a world of limited resources, and those resources are in Iraq", said one senior American official, interviewed by Sanger his book. ${ }^{80}$ Most experts and scholars could agree that the greatest miscalculation of Bush's administration was the premature statement of victory over the Taliban enemy. On the eve of that declaration, that Americans moved on to Iraq, when in reality the Taliban had not been defeated. Experts and scholars, and probably later historians, will continue to argue whether a fuller commitment at the beginning would have prevented for Americans and NATO the problems of later years, and the establishment of a safe haven for Taliban and al Qaeda across the Pakistan border. But for many Americans who had gained experience on the ground in Afghanistan, Bush's decision to make Iraq a "central front" in the war on terror was more than mistaken and his successors will be trying to solve this problem for a long time. ${ }^{81}$

According to Gen. James Jones, the complexities of the Iraq invasion were the main concern until late 2007, to such a degree that the Afghan theatre had become a "forgotten war". ${ }^{82}$ Thus from the late 2002 American efforts had shifted to the west, toward Baghdad. This started with the transfer of Intelligence and Special Forces to Iraq, which created a vacuum in Afghanistan that the Taliban, although notably weakened, could begin to fill. On the eve of Iraqi invasion the CIA launched a massive intelligence operation inside Iraq, in fact, twice the size of a similar effort two years before in Afghanistan. The most skilled counterterrorism and Middle East specialists and paramilitary authorities were transferred to Iraq. Thereby reduced was American influence on very important and powerful Afghan warlords, who refused to turn over to Kabul money (probably tens of millions dollars) which they had obtained as routine payments at border crossings. Experienced agents were replaced by younger officers who could not make the case to the tribal authorities that their longterm interests required supporting a stronger central government in the capital city. Robert Grenier, the former director of the CIA's counterintelligence center, concluded: "I think we could have done a lot more on the Afghan side if we had more experienced folks (...) if you don't have those

\footnotetext{
${ }^{79}$ Ibid., 115-116.

${ }^{80}$ Ibid., 138.

${ }^{81}$ Ibid., 168.

${ }^{82}$ Ibid., 167.
} 
relationships, your ability to influence goes down". Moreover, not only the intelligence service lost its bearings, but also American Special Forces lost their center of interest on the leading target of all: al Qaeda Central, which found safe haven over the border in Pakistan. ${ }^{83}$ The Taliban's resurgence became cut from the same cloth as al Qaeda's resurgence and their association was a sort of twoway street -"the Taliban provided a safe haven and a support network; al Qaeda paid them in training, expertise, and financing." ${ }^{\prime \prime 4}$ While U.S. Special Forces were engaged in Iraq, both bin Laden and the Taliban found the occasion that they needed to recreate small training camps and conduct fearless strikes into Afghanistan. ${ }^{85}$ Officially, the Bush administration denied that conditions in the tribal neighborhood had spun out of control. But in fact the phenomenon of insurgency appeared, and it become something for which global hegemon and its allies were not prepared. ${ }^{86}$

Secondly, the United States was insufficiently interested in rebuilding the country from the bottom up and when the war with Iraq started, they paid even less attention to this issue. It was easy to employ military force and invade the country, but it is much more difficult to rebuild it later, especially on such complicated soil. ${ }^{87}$ The essential concern of the nation-building effort in Afghanistan was that this country, since the beginning of statehood, had never been a nation according to the Western definition. Moreover, the people who inhabit this country, beginning with tribal leaders, had not been attracted by the vision of creating one. Afghanistan is situated among the world's poorest and most underdeveloped countries, with appalling illiteracy and extremely low life expectancy (forty-three years). From the beginning of the invasion the United States did not have sufficient infrastructure for civilian reconstruction, and not until its second term in the office did the Bush administration attempt to build one. The help which Afghanistan had been receiving was simply insufficient. Robert Finn, the American ambassador to Afghanistan from 2002 to 2003, said "Afghanistan has been founded at lower level than any other postwar humanitarian crisis... I said from the get-go that we didn't have enough money and we didn't have enough soldiers. ${ }^{\prime 88}$ Six years

\footnotetext{
83 Ibid., 136-137.

${ }^{84}$ Ibid., 167.

${ }^{85}$ For Sanger, the issue of transferring remotely piloted spy planes -Predators - to Iraq also created a very significant disadvantage for Special Forces operations in Afghanistan.

${ }^{86}$ Sanger, Inheritance, 167-170.

${ }^{87}$ Chollet and Goldgeier, America Between the Wars, 328.

${ }^{88}$ Sanger, Inheritance, 129-130.
} 
later Finn was still convinced this problem had not yet been solved. Two years after the American invasion, international aid to Afghanistan (\$57 per capita) was shockingly low in comparison not only to Iraq, but such countries like Bosnia (\$679) and East Timor (\$233) with much less strategic importance to the United States. The case of Iraq especially reveals how small the amount of money that was allocated for Afghanistan. In the early years, after the American invasion to oust Saddam Hussein, Iraq received about $\$ 18$ billion for reconstruction over a period of several years. The aid which was allocated for Afghanistan in 2004 is estimated around \$720 million. Having in mind that Iraq has a lot of oil reserves and its reconstruction is supposed to be self-financing by income from them, Afghanistan needed much more help than Iraq. ${ }^{89}$

Thirdly, the Bush administration itself not only failed to employ the proper tactics in regard to Afghanistan, but also, when it decided to share responsibility with NATO allies, could not produce a common strategy for winning in Afghanistan. NATO members had showed up on Afghan territory with a different mission from that presented by the United States, the core of which was counterterrorism. The Americans focused on hunting down al Qaeda and the Taliban with the aim to eliminate them. The allies in contrast signed on as a peacekeeping force and focused on reconstruction. ${ }^{90}$ Simply, the NATO allies provided political cover, not covering fire. To make it more difficult, each NATO member operated under its own rules of combat and did not want to take risks and casualties. General McNeil concluded: "The problem with alliance warfare is that every country puts its national interest first and the alliance second. Every decision takes longer. Plans leak. It's an interesting way to try to win a war". ${ }^{91}$

At the start, the Bush administration opposed NATO's involvement in the war, but later encouraged the alliance to join the mission, becoming aware that it needed to share the responsibilities for the long campaign. Allied participation gave the mission an international patina whose purpose was to decrease and displace the impression of American occupation. ${ }^{92}$ In July 2006, NATO formally became responsible for security in southern Afghanistan and in late 2006 in the eastern part of the country.

\footnotetext{
${ }^{89}$ Ibid., 140-141.

${ }^{90}$ Timo Noetzel and Sibylle Scheipers, Coalition Warfare in Afghanistan: Burden-sharing or Disunity? (London: Chatham House, The Royal Institute of International Affairs, October 2007), 1-8.

${ }^{91}$ Sanger, Inheritance, 113-114.

92 Ibid., 114.
} 
At that time, it was already clear that NATO's reconstruction plans could not succeed when the Taliban were retaking villages and destroying schools faster than coalition countries could build them. By 2008, when the Taliban counterinsurgency intensified, the division between NATO allies and the United States turned into a nightmare, because of their different attitudes to the mission goals (not only to the military dimension of the mission, but also in reference to political aspects of NATO's role in Afghanistan). One former key commander of American forces, interviewed by Sanger pointed out: "Clearly, the Europeans do not see Afghanistan the way we do (...) They see it in terms of national reconstruction. We see Afghanistan as forward defense, and we are the only country willing to absorb significant casualties." ${ }^{93}$

During the first term of Bush's Presidency the real lesson of the Afghan war had gradually come out: "While the United States wields the world's largest hammer, not every problem is a nail."194 In Kilcullen's view the United States had been "overconfident after the fall of the Taliban". ${ }^{95}$ Filled with arrogance of military power, inadequately interested in terms of nation-building effort from the bottom up, and keen to believe in Pakistan President Musharraf's promises, the Bush administration forgot its fundamental objective: the destruction of the Taliban and al Qaeda. The international aid finally flowed into Afghanistan years later, but in a country plagued by corruption this money could not be properly and efficiently used. By his second term Bush and the most powerful figures around him understood that without a good strategy for reconstruction all military gains since the beginning of the operation would be lost. ${ }^{96}$ At the end of his presidency - although 2008 opinion polls indicated that a vast majority of Afghans supported America's presence and were opposed to the Taliban regime - Bush had little room for maneuver to convince Afghans there was a real substitute to life under the hated Taliban regime and to an economy dependent on poppies income. Thus, Afghans became concerned whether America had the will to make a difference. ${ }^{97}$ Before the Bush administration had ultimately realized that winning in Afghanistan needed a greater commitment, almost irreparable damage had been done when Afghanistan started to return to anarchy. ${ }^{98}$ All

\footnotetext{
93 Ibid., 163-164.

94 Ibid., 134.

${ }^{95}$ Ibid., 124.

${ }^{96}$ Ibid., 134.

97 Ibid., 125

98 Ibid., 134.
} 
available data from 2006/2007 shows that opium production mushroomed and that Afghanistan became the world's first producer of heroin and money from the narcotics trade generated half of Afghanistan's GDP. Afghanistan once again had become an narco-state. The largest part of the production was in the southwestern part of the country, Helmand Province, and the Taliban not by accident were strongest on that territory, and became financed by the drug trade. ${ }^{99}$ The United States and NATO failures on the Afghanistan-Pakistani border between 2002-2008 are a clear example of strategic distraction. ${ }^{100}$ For some experts, the United States lost track of defeating al Qaeda and Taliban by not only giving prioritization to Iraq, but also by treating Afghanistan and Pakistan as separate problems, not a single battlefield, although Taliban and al Qaeda treated this cross-border territory as a single tribal land. ${ }^{101}$

Gen. Douglas Lute spoke the "terrible truth" in 2007 - "The truth is that you have to think about this problem in thirty-year terms". In 2008 he revised his assumption to fifty-years. ${ }^{102}$ But no one wanted to face the hard reality that wining in Afghanistan could mean staying there for decades. ${ }^{103}$ Another important general, Kilcullen, who helped to rewrite the Defense Department's strategy for "Iongduration unconventional warfare", stated that this kind of war "involves everything Americans are worst at", beginning with patience. Thus, according to Sanger, "the Taliban reached an obvious conclusion: Their greatest weapon was not the car bomb or the roadside IED, the improvised explosive devices that caused devastating injuries. Instead, it was American tentativeness, an unwillingness by Bush or other officials to commit troops, money, and resources for the years, if not decades, it would take to rebuild the country."104

\footnotetext{
99 Ibid., 166.

100 Noetzel and Scheipers, Coalition Warfare in Afghanistan, 1-8.

${ }^{101}$ What, by some British officers, was called Pashtunistan.

102 Sanger, Inheritance, 119.

103 Ibid., 170.

${ }^{104}$ Ibid., 119-123.
} 


\subsubsection{Obama's “Winning in Afghanistan" Strategy}

"I took office at a time when many around the world had come to view America with skepticism and distrust. Part of this was due to misperceptions and misinformation about my country. Part of this was due to opposition to specific policies, and a belief that on certain critical issues, America has acted unilaterally, without regard for the interests of others. And this has fed an almost reflexive antiAmericanism, which too often has served as an excuse for collective inaction."

- President Obama, Address to the United Nations General Assembly, September 23, 2009

When Bush finally finished his second-term in office and handed power over to Obama, American society was overwhelmingly disappointed with his presidency. ${ }^{105}$ Rather than the unsuccessful Afghan stabilization mission, the unpopular and controversial Iraqi war was the leading reason for both public anger at home toward American foreign policy and the decline of America's moral authority overseas. ${ }^{106}$ Using the idea of promoting democracy, Bush and his team made it "radioactive at home and abroad". According to Madeline Albright, "They give democracy a bad name." ${ }^{107}$ Barack Obama started his presidential campaign promising that he would seek to renew America's relationship with the world. The signaled break with his predecessor's foreign policy was proved during the first year of his presidency in a series of ambitious speeches about sharing global challenges together with other nations. If Bush generally saw things in, lets say, "conservative glasses" - "us versus them", Obama started to come back to Clinton's "liberal" perception of the world - "us and them". ${ }^{108}$ Although his approach to foreign policy gave him much support, especially at home, the first years of his presidency show that it will be genuinely hard to fulfill his goals. ${ }^{109}$

\footnotetext{
${ }^{105}$ Bush was even more unpopular in American society than President Nixon at the time of the Watergate affair, see Jan Tokarski, “'Zmiana’ bez zmiany”, Analizy Natolińskie, 9, 32, (2008), 1-2.

${ }^{106}$ Kristin M. Lord and Marc Lynch, America's Extended Hand. Assessing the Obama Administration's Global Engagement Strategy (Washington, D.C.: Center for a New American Security, June 2010), 1.

${ }^{107}$ Chollet and Goldgeier, America Between the Wars, 319.

${ }^{108}$ Ibid., 326.

${ }^{109}$ Lord and Lynch, America's Extended Hand, 1-3.
} 
Although there are important differences in Obama's engagement strategy toward Afghanistan in comparison to Bush's approach, there is also a solid succession to the $43^{\text {rd }}$ administration's policies and philosophies, which it tried to implement in its final two years. ${ }^{110}$ Since the decision in late December to strengthen American's military commitment in Afghanistan, and to treat it together with Pakistan as a single battlefield area, the Obama administration's public engagement strategy, according to Kristin Lord and Marc Lynch, encompassed several elements:

- Among NATO allies, build public support for, and limit public opposition to, civil and military assistance in Afghanistan and Pakistan.

- In Afghanistan and Pakistan, counter Taliban and extremist narratives and undermine links between local narratives and the global al Qaeda narrative, while empowering Afghans and Pakistanis to counter extremist narratives.

- Reverse the trend toward greater anti-Americanism in Pakistan, while encouraging public support for counterinsurgency strategies in Afghanistan and Pakistan.

- Fight Taliban and extremist networks in Afghanistan and Pakistan in ways that minimize public discontent and opposition.

- Communicate successes on the battlefield to publics, whose support will depend at least partially on whom is perceived to be winning, and prevent enemies from manipulating information and images in ways that challenge that perception.

- Enhance the legitimacy of indigenous governments in Afghanistan and Pakistan to build the capacity of those local and national governments to sustain good governance and render U.S. and NATO support unnecessary.

- Strengthen long-term relations between the people of Afghanistan and Pakistan on the one hand and Americans on the other. ${ }^{111}$

The Obama administration's principal objectives in public engagement, both in Afghanistan and Pakistan, are dependent on the support of doubtful alliances with the governing regimes and popular support. In Gen. Stanley McChrystal's view, the principle strategic communication effort tries to

\footnotetext{
${ }^{110}$ Mark Lynch, Rhetoric and Reality. Countering Terrorism in the Age of Obama (Washington, D.C.: Center for a New American Security, June 2010), 1-2.

${ }^{111}$ Lord and Lynch, America's Extended Hand, 32.
} 
"maintain and strengthen the Afghan population's positive perception of and support for" the central government in Kabul and the commitment of the International Security Assistance Force (ISAF) and international community. ${ }^{112}$ Although the Obama administration can already show some success, for example in additional NATO members' contribution to the ISAF mission in the fall of 2009 and the Netherlands' renunciation of the intended withdrawal of 2000 troops from Afghanistan, by the end of 2010 an alarming trend could be perceived. However there is no denying that Obama's new civilian strategy in Afghanistan, to gain support of the population, could have positive effects. Moreover, for the first time this strategy has been followed by considerable resources and effort. However, this strategy could succeed only when the United States and Afghan government not only battle corruption but also convince the Afghans of that priority. Additionally, now or never, the United States together with NATO have to make Afghans warm to their presence, that they are not occupying army, and they are capable of controling Afghan territory, protect the people, and ultimately bring stability. It looks as if this strategy contains much more positive elements in comparison to Bush's approach, but it needs to be constantly evolving and show tangible progress. In the case of Pakistan, the effort at gaining public support is far from successful and a change in people's attitudes is likely to be slow and long. Thus, "the role for public engagement is therefore to accentuate areas where this is happening, build strong relationships with opinion leaders, and contribute to a foundation of trust in which American actions might be interpreted less negatively and its intentions might be less suspect." ${ }^{\prime 113}$ It seems that Barack Obama started effectively in moving away from the Bush's strategy on "Global War on Terror". ${ }^{114}$ But even so, the Bush administration's unresolved issues in Afghanistan and Iraq and massive misjudgments about correct strategy, means that Afghanistan will create even greater challenges to Obama than it did to his predecessor. Obama probably would like to decrease American commitment in Afghanistan, but he knows that without American effort and leadership it will be impossible to solve the Taliban and al Qaeda problems, which can pose again a serious threat to the world superpower.

\footnotetext{
${ }^{112}$ Andrew Exum, Leverage: Designing a Political Campaign for Afghanistan, (Washington, D.C.: Center for a New American Security, May 2010), 17-18.

${ }^{113}$ Lord and Lynch, America's Extended Hand, 32-36.

${ }^{114}$ Mark Lynch, Rhetoric and Reality, 5-6.
} 


\section{Central European Countries' Engagement in the Afghan Stabilization Mission.}

To this point this paper has focused on the general information about ISAF mission and American foreign policy toward Afghanistan under Bush and Obama's administrations. Each mission has a landmark event or distinct factors which shape the final outcome of the operation. And as I tried to emphasize in the previous chapter, the most probable answer to the question why the things went wrong in Afghanistan can be found in the American approach to the war on terrorism - Afghanistan, in contrast to Iraq, was simply too low in the hierarchy of the war against terrorism. But American foreign policy has also another important dimension in the context of Visegrad group member countries. In essence, American foreign policy is applicable to the on-going worldwide policy debates, also in the Central European region, about where the United States can find reliable allies.

From the beginning of the Operation Enduring Freedom, NATO had offered support to the stabilization mission on Afghan soil. However, The United States strategists and policy-makers were unwilling to place international forces and themselves under a multinational command and NATO's "consensus-oriented decision-making procedures" - which ineffectiveness was strongly remembered from the Kosovo campaign. Even so, being aware that the only alternative could be sending larger numbers of their own troops with the aim to stabilize and reconstruct the Afghanistan, the United States had no other way than to accept European support for the operation. ${ }^{115}$

However, the Europeans had contributed troops to the operation on the basis of a loose consensus, and as the consequence their reasons for doing so varied greatly. The United Kingdom, likewise Germany, were motivated to strengthen the transatlantic security framework, while another major actor, France, saw European commitment to the mission in the terms of a genuinely emerging European security identity. Regardless of major European countries reasons to participate in the mission, the real question to answer is what precisely moved Central European countries to participate, and how large was their contribution in comparison to older NATO members. ${ }^{116}$ Thus, my focus in the following chapters is on Central European countries' participation in the ISAF mission with the broader international context and its outcome for American - V4 countries relations.

\footnotetext{
${ }^{115}$ Noetzel and Scheipers, Coalition Warfare in Afghanistan, 3.

${ }^{116}$ Ibid., 3.
} 


\subsection{Where Have You Come From and What Do You Want? Interests Analysis}

Joining the North Atlantic Treaty Organization was one of the main priorities of the Visegrad Group member countries' foreign policy since the 1990s. After five years of planned participation in the Partnership for Peace Program, Czech Republic, Hungary and Poland finally became a members of the Treaty in March, 1999. Unfortunately, due to unfavorable conditions, the path into NATO became for Slovakia much longer than the other V4 countries and took Slovakia five more years to become a full member. ${ }^{117}$

The fundamental role of NATO in Central European countries' security can be found in basic strategic documents which shows that in the XXI century NATO became the main pillar of V4 member countries' security policies. Visegrad group member countries confirm that NATO is fundamental for their security situation and security and stability in the transatlantic space. Among the prerogatives of their foreign policy agenda, V4 countries emphasize the great importance of strengthening transatlantic relations.

In accordance with the Czech Republic's Security Strategy (adopted in 2003 and modified in 2007), Prague visualizes a strategic partnership between EU and NATO as "the basis of security in the EuroAtlantic area" ${ }^{118}$ In the eyes of Warsaw, NATO seems to be the best guarantee of Polish sovereignty from any aggression. ${ }^{119}$ According to the National Security Strategy of Poland adopted in 2007, "the North Atlantic Alliance is for Poland the most important form of multilateral cooperation in a political and military dimension of security and a pillar of stability on the European continent, as well as the main platform of trans-Atlantic relations". In Slovakia's perception, NATO is "the only real security guarantee" and "a key strategic security forum" for peace and stability, both in Europe and the world. For Hungary NATO is also at the core of its security policy. ${ }^{120}$ In regard to NATO, Budapest believes that "more effective forms of co-operation are needed in adapting partnership co-operation,

\footnotetext{
${ }^{117}$ http://www.visegrad.info/european-security-transatlantic/factsheet/european-security-and-transatlanticrelations.html

${ }^{118}$ Beata Górka-Winter and Marek Madej, NATO Member States and the New Strategic Concept: An Overview. (Warsaw: The Polish Institute of Foreign Affairs, May 2010), 20.

${ }^{119}$ http://www.visegrad.info/european-security-transatlantic/

${ }^{120}$ Górka-Winter and Madej, NATO Member States, 20, 56, 79, 94.
} 
giving greater consideration to the specific needs of individual countries and regions(...)" and "(...) For this reason, Hungary has an interest in a gradual and flexible development of the current partnership frameworks while keeping the transatlantic nature of the Alliance intact. In terms of developing partnership, Hungary offers greater attention in supporting three new PfP members from the Balkans (Bosnia-Herzegovina, Serbia, Montenegro), and expects this support to yield stability and security in its neighbourhood. Ukraine, Russia and the European CIS countries are also of primary importance for Hungary" - concludes the note of the Hungarian Foreign Ministry. ${ }^{121}$

\subsubsection{Security Conditions of the Central European Region in the XXI century}

NATO's enlargement (and that of the EU as well), considerably changed the security environment in Central Europe. Central European countries became an integral part of the "West" in politicalmilitary terms, and in economic affiliations as well. New EU members no longer belong to a "Europe between" - the object of geopolitical games between West and East. On this account, permanence and stability of integration processes in Europe is probably the most important security condition of the Central European region. ${ }^{122}$ When the fundamental and common aim of CEC was to join both NATO and EU, they conducted a relatively joint foreign policy. A substantial shift of interest occurred in these countries when their goals were achieved. Thanks to EU funds, Central Europe has accelerated its economic development and cultural advance. Thus all CEC are in favor of maintaining the EU budget on sufficient levels. Unfortunately, all remaining interests often became different or divergent. Such circumstances heterogeneities and fragmentize the nature of links uniting them, with the exception of the security interests vis a vis the neighboring Russian Federation. ${ }^{123}$ The reason is that Central Europe - especially Central-Eastern Europe, considered as an intermare territory - is not uniform in terms of recognized threats. In substance the differences in this regard exist between the southern and northern parts of this region. For the northern part of the region, the proximity of Scandinavia has become a factor which positively influences internal and external stability, as does the proximity of Germany depending on the current status of relation between Berlin and CEC (and also between Berlin and Moscow). ${ }^{124}$

\footnotetext{
${ }^{121}$ http://www.visegrad.info/european-security-transatlantic/

${ }^{122}$ Kamiński, Polityka Bez Strategii, 20.

${ }^{123}$ Ibid., 119.

${ }^{124}$ Ibid., 21.
} 
In this regard, we can observe that V4 countries geopolitical position with the accession to the EU took on another dimension. Poland, with its 1143-km Eastern border, now posses the longest continental border with the non-EU states. The border issue became a security and foreign policy priority for all V4 countries, except for the Czech Republic which neighbors only other EU states. Warsaw focuses its neighborhood policy on two Eastern European countries, Belarus and Ukraine, while Prague is less occupied by this issue. The core of Budapest's policy is its southern orientation and the Western Balkans area. For that reason, since the EU enlargement, Poland became the country most involved in the Eastern dimension of the EU policy, and creates this policy agenda within the Eastern Partnership framework (particularly aimed on the integration process for Ukraine), which is considered by Russia as interference into its sphere of influence. ${ }^{125}$

The conceptualization of security policy differs in Central European countries, and to some extent, represents different attitudes toward Moscow. The major and immediate threat is attributed to neoimperial Russian foreign policy (although Slovakia's openness to Russia contradicts this thesis). Moreover, due to the historical past and geopolitical vulnerability Warsaw is very sensitive to close German-Russian cooperation which in Polish history has had only bad connotations for maintaining national sovereignty. To bring about the submission of Central and Eastern European countries, Moscow tries to take advantage of their energy dependence. The Kremlin has also made efforts at destabilizing the internal situation of Soviet successor states to prevent the consolidation of the status quo. ${ }^{126}$ The real existence of a threat from Russia emerged when Moscow launched a conventional attack on Georgia in 2008 and when the Russian President, Dmitri Medvedev, publicly warned that he would give an order to deploy Russian missiles with nuclear warheads in the Kaliningrad region, if the United States implemented its missile defense plans in the Czech Republic and Poland. Meanwhile, Russia's attempts aimed at keeping Europe and Washington away from its "near abroad" following the "colored revolutions" in Georgia and Ukraine, together with plans of expanding economic cooperation with European states from the position of a great supplier of energy was considered by Poland as a Russian revisionist foreign policy. ${ }^{127}$ Thus, in these terms Poland has rather more similar security interests to Russia's immediate neighbors - Estonia, Latvia,

\footnotetext{
${ }^{125}$ Laszlo J. Kiss, Central Europe: 'Imagined Spaces' and Challenges of the $21^{\text {st }}$ Century. (Foreign Policy Review, Vol. 7, 2010), 93.

${ }^{126}$ Kamiński, Polityka Bez Strategii, 21.

${ }^{127}$ Kiss, Central Europe, 91.
} 
Lithuania - than to other members of V4 group. ${ }^{128}$ Nevertheless, the close relationship of Russia and Germany in the XXI century - when Berlin as a major power in the EU and NATO became also allied with the V4 countries and a major advocate of Polish interests in the EU - does not represent a threat for conventional aggression, and by the same token a real security threat from this side for Poland in the XXI century. ${ }^{129}$ Therefore, many factors have played a role in the engagement of V4 into the ISAF mission in Afghanistan, however, it seems not to be caused by security conditions of the region in accordance to real threat from Russia. We have to bear in mind that Germany, Poland and Russia at present times are in a similar positions in many ways after the collapse of Soviet bloc. They found themselves in a different geopolitical situation and had to find new identities as they faced threats in new era. Poland, although its borders did not change, had to deal with 7 new neighbors. However, for hundred years Poles do not face the old question, extremely important to the country's existence: "With Russia against Germany or with Germany against Russia?". The re-evaluation of foreign policy agenda had significant geopolitical justification: the geographical location of Germany - Poland - and Russia and their future role in the new European security system. Germany paid a considerable price for the country's unification and since that has had to deal with problems of both the East and the West. In turn, Russia has to cope with European and Asian challenges. On the other side is Poland, lying between these major European countries, simply a borderland which exemplifies both the economic border of the EU and the security border of NATO. New countries who lay between Russia and the V4 countries and their relations to Moscow and to the West have not been made clear yet. ${ }^{130}$

From a global perspective the EU is a sub-region of the world. In other words, the security of the EU can not be considered apart from the nature of processes that are shaping the world and their associated risks. Moreover, it is also linked with other world regions with whom the EU competes or from where these risks come from. This is more important, given that currently we are observing rapid changes in the global order, which have resulted in a gradual decline of the West's current position (i.e. the EU and US) in favor of East and South Asia (China and Indie). "The feature that

\footnotetext{
${ }^{128}$ Kamiński, Polityka Bez Strategii, 119.

${ }^{129}$ Kiss, Central Europe, 93.

${ }^{130}$ Ibid., 94.
} 
distinguishes the international security system that has persisted since $13-14$ years is ambiguity, uncertainty and unpredictability." ${ }^{131}$

Moreover, due to the threat of terrorism, contemporary notions of security have erased the border between internal and external security. All institutions - not only within particular countries, but also on the EU level, have to a greater or lesser extent been made responsible for security issues. ${ }^{132}$ When a new security situation emerged after 9/11, the proliferation of WMD and existence of rogue regimes became the major threats for Western security, and therefore for Central European countries as well.

During the Cold War and past decades, the Alliance limited itself to concentration on defense preparations and necessary mobilization of armed forces aimed to deter or repel an attack from neighboring territories. At the turn of century NATO faced new and diverse challenges. In April 2009, NATO adopted a new Strategic Concept at the Washington Summit and as the result the Alliance policy related to "out-of-area" mission was changed. ${ }^{133}$ The present concerns of NATO members are still related to threats to borders security as a consequent regional disputes or attempts aimed at political intimidation of allied states (this matters a lot to all Visegrad group member countries). Warsaw and the Baltic states became known as the advocates of the orthodox group, emphasizing the significance and rationalization of NATO's original idea, and its anti-Russian approach. ${ }^{134}$

Regardless of these factors, NATO has to face threats which are more various and less foreseeable acts of terrorism, proliferation of advanced military technologies (including nuclear technology), cyber attacks, sabotage acts against pipelines, etc. In many cases effective defense against these threats must begin far away from the NATO members territories. The Alliance has already reacted to this new reality and consequently supported the new Afghan authorities in their fight against extremism. ${ }^{135}$

\footnotetext{
${ }^{131}$ Kamiński, Polityka Bez Strategii, 36.

${ }^{132}$ Ibid., 28.

${ }^{133}$ Chappel, What Future for, 1.

${ }^{134}$ Kiss, Central Europe, 93.

135 Adam Daniel Rotfeld, ed. NATO 2020. Zapewnione Bezpieczeństwo, Dynamiczne Zaangażowanie, (Warszawa: Polski Instytut Spraw Międzynarodowych, 2010), 33.
} 
The ISAF mission in Afghanistan is definitely the largest operation that NATO has ever undertaken in its history. Each member of the Alliance contributed to the operation, and a majority of them gradually increased their engagement, including the V4 member countries. ${ }^{136}$ The Afghan stabilization mission is a new challenge for Central European countries in the XXI century, and probably the most important and the most difficult mission for Central European armed forces. It is clear that is in the interest for Central European countries to strengthen the Alliance and participate in the constant validation of its political and military credibility. In addition the Afghanistan mission provides the opportunity to gain invaluable experience for Central European armed forces. Central European perceptions of the prestige and importance of the alliance implies their active participation in international missions conducted by NATO. Central European countries cannot claim from the North Atlantic Alliance costly investments or seek to deploy its bases in their territory and at the same time say that their armies and soldiers will remain in their barracks. Central European countries (especially Poland) want to be present as major actors of the stabilization mission in Afghanistan. ${ }^{137}$ The success of the operation will confirm the credibility and strengthen the cohesiveness of the Alliance. The failure of the NATO-led ISAF mission would weaken the Alliance, and de facto, one of the pillars of Central European security. The triumph of the Taliban could also lead to destabilization of a whole region, starting in neighboring Pakistan. ${ }^{138}$ Finally, CEC's performance on Afghan soil has direct implications for their relations with the United States. ${ }^{139}$

\footnotetext{
136 Ibid., 35.
}

${ }^{137}$ Winid, Udział Polski w Działaniach Stabilizacyjnych, 10.

138 Taking control of Pakistan - which possesses nuclear weapons - would for example, inflame current tensions with India over Kashmir. Escalation of such conflict could lead to use of nuclear weapons by one of the conflicting sides. If we consider India's conventional military advantage and the extremely low control of the Pakistan establishment over atomic complex, it would be definitively Pakistan ; see Kamiński. Polityka Bez Strategii, 90.

${ }^{139}$ In case of Poland, Polish engagement in the mission has also an important historical and moral aspect. We have to consider that Soviet intervention in Afghanistan at the beginning 1980s probably prevented Moscow from undertaking a decision to suppress the Solidarity movement. Moreover, the intervention costs of the Soviet Army in Afghanistan exceeded in total $100 \mathrm{mln} \$$, what caused the Soviets to become bankrupt and as a consequence to the demise of whole communistic bloc. There was no telling what would happen if during the moment of changes in Europe on 1989, the Soviet Union would have had greater economic strength. The changes could have taken the Chinese way of transformation - with opening of the market, but keeping an undemocratic political system. In: Winid, Udział Polski w Działaniach Stabilizacyjnych, 10. 


\subsection{Central European Countries contribution to the ISAF mission and their primary tasks}

When Central European countries entered NATO, together with other members they became obliged to participate in foreign military operations under the Alliance flag. Once NATO had seized command over the ISAF operation in August 2003, it forced the member countries to give greater focus on that mission. Poland has been participating in the actions undertaken by the international community in Afghanistan since March, 2002. ${ }^{140}$ The Czech military forces have participated in NATO's mission in Afghanistan since 12 March $2004 .{ }^{141}$ Since 2003, Hungary has contributed actively to the ISAF mission and from year to year has taken on responsibilities relative to its combat and reconstruction capabilities in performing stabilization tasks (but all V4 countries are recognized as a Troop Contributing Countries since 2003). ${ }^{142}$ The initially slight engagement of all V4 countries was criticized in Brussels and in Washington. Poland, the largest V4 country, was continuously under pressure to increase the scope of involvement in NATO operations in Afghanistan. Other members of Visegrad group were also criticized for lack of commitment. At the beginning of 2005, the Polish government, noticing that its engagement in NATO's stabilization activities in Afghanistan was inadequate to the potential, capabilities and importance of Poland within the Alliance, started work to increase Polish participation in the mission. ${ }^{143}$

\footnotetext{
${ }^{140}$ Ibid., 6.

${ }^{141}$ http://www.centcom.mil/czech-republic/

${ }^{142}$ http://www.mfa.gov.hu/kum/en/bal/foreign_policy/security_policy/hungary_in_nato/hungary_role_in_afgh anistan/

${ }^{143}$ Winid, Udział Polski w Działaniach Stabilizacyjnych, 8.
} 




Source: http://www.isaf.nato.int/isaf-placemat-archives.html (Archive Placement valid as of 16 August 2011)

The Czech Republic, Hungary and Slovakia also wanted to take on an increased burden of activities. For Central European countries the ISAF mission in Afghanistan become one of the greates military challenges which they had to face in recent years. Certainly, the ISAF stabilization mission is carried out in cultural, civilization and climatic conditions which entirely diverge from European realities. ${ }^{144}$ Central European contingents undertaking activities within the NATO framework have given support to legally elected Afghan authorities. The success of international forces depends not only on military activities, but also on a complex approach which was abandoned at the beginning phase of the American invasion of Afghanistan. Central European forces in Afghanistan carry out tasks related to counter-drug business activities, protecting borders, building roads, spreading education and in the meantime accommodate them to conditions of an Afghan society with society based on clans and tribal bonds. Therefore, an important element of ISAF mission are the rebuilding and reconstruction activities carried out within Provincial Reconstruction Teams. Central European forces within ISAF are

\footnotetext{
${ }^{144}$ http://www.isaf.wp.mil.pl/pl/15.html
} 
also responsible for training Afghan security forces, to help them further take over responsibility for the country's security. ISAF forces, and Central European contingents within them, are thus considered more positively among Afghan society - not as occupying forces but as a guarantors of stability and security. ${ }^{145}$

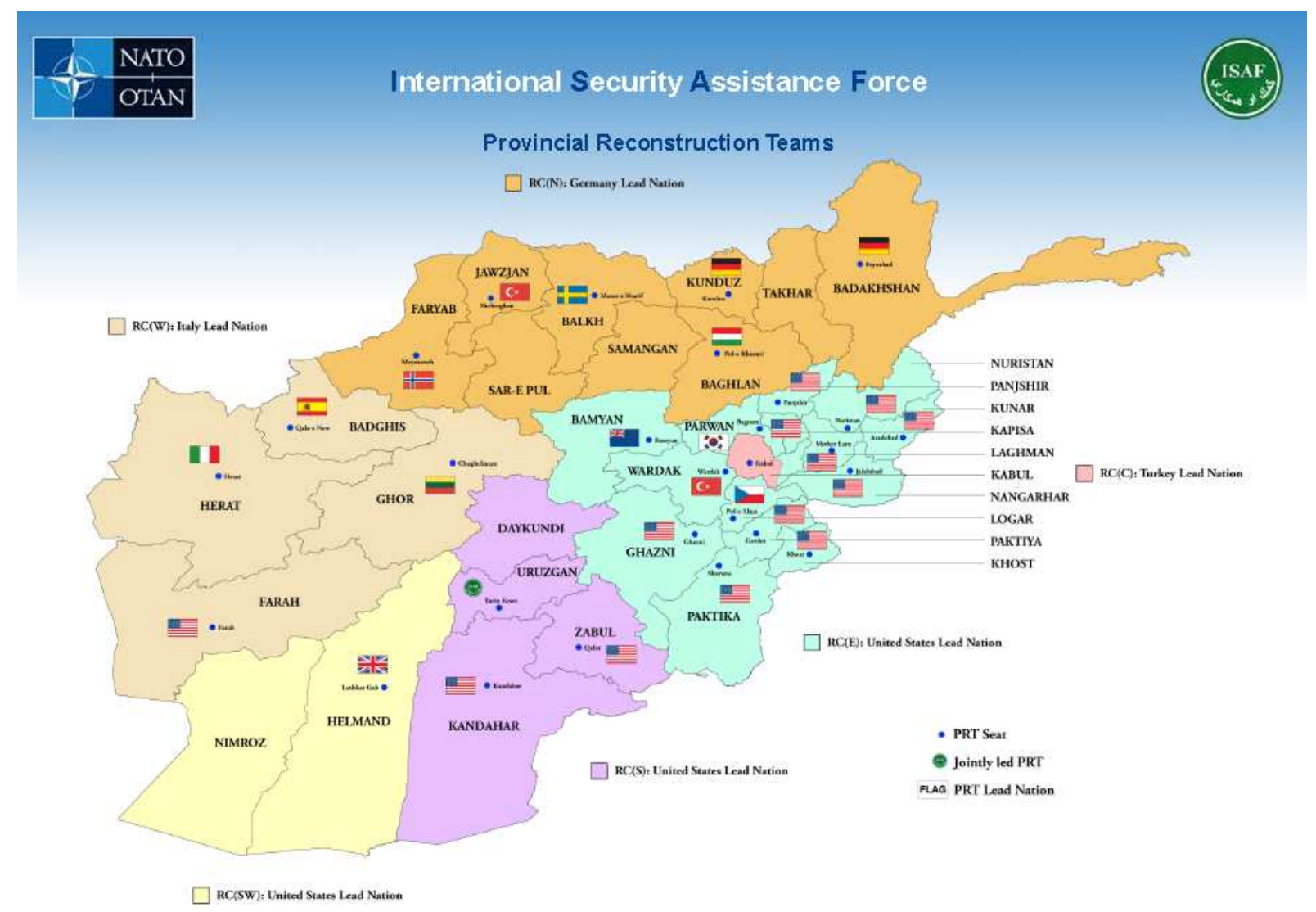

Source: http://www.isaf.nato.int/isaf-placemat-archives.html (Archive Placement valid as of 16 August 2011)

${ }^{145}$ Winid, Udział Polski w Działaniach Stabilizacyjnych, 17. 
International Security A ssistance Force

Regional Commands, Major Units, Provincial Reconstruction Teams

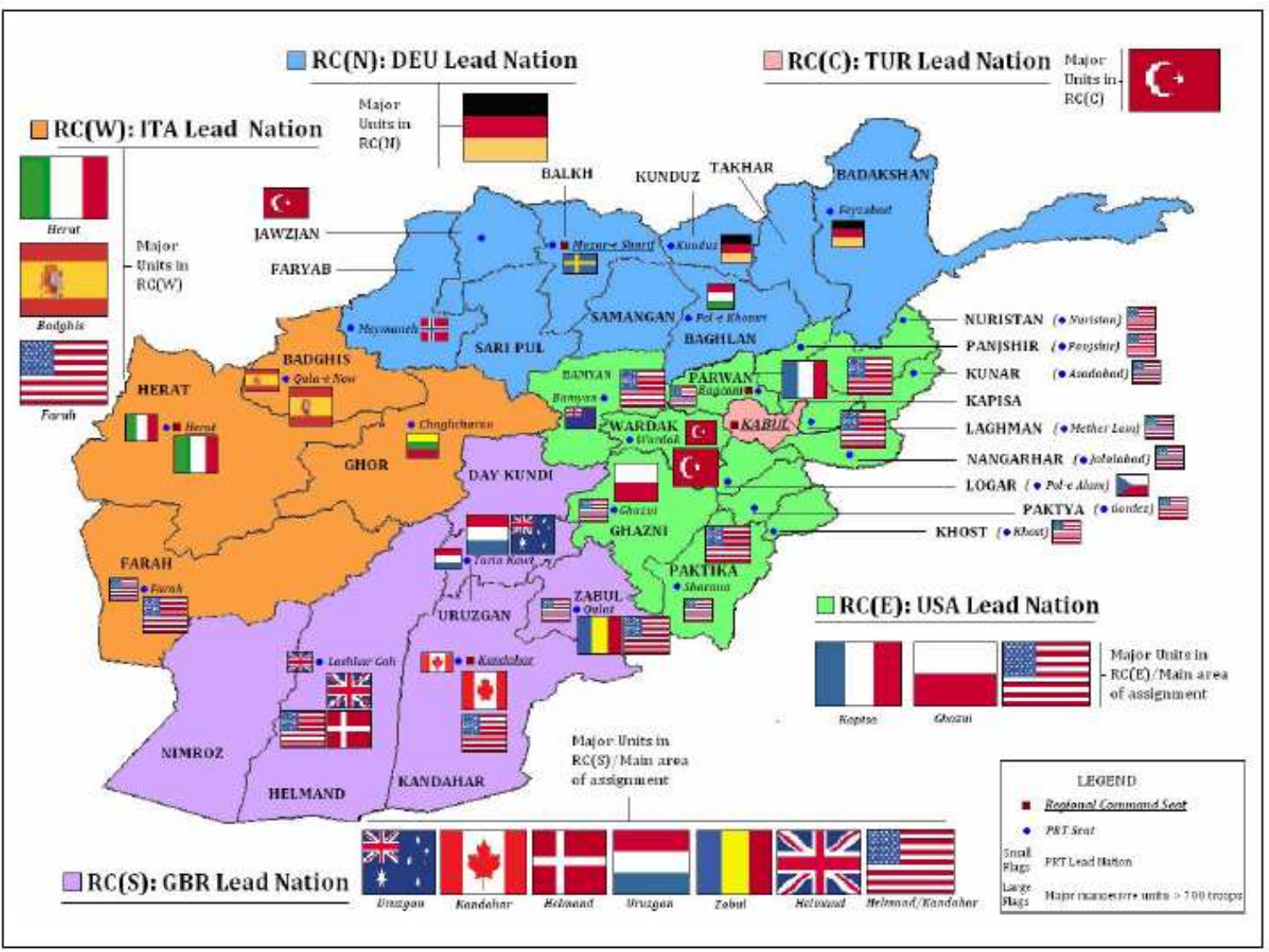

7 June 2010

Source: http://www.isaf.nato.int/isaf-placemat-archives.html (Archive Placement valid as of 7 June 2010)

\subsubsection{Czech Republic}

The Czech Republic executed its contribution to the peacekeeping mission within ISAF, FINGAL Operation, by deploying armed forces to Afghanistan in May, 2002. The military contingent was a part of $6^{\text {th }}$ Field Hospital $(\mathrm{FH})$, a platoon of guards and a Military Police team. In total, Prague deployed a 269-strong military contingent in the FINGAL operation untill January 28, 2003. Since February 1, 2003, 11-member Czech field surgical teams were also structured interchanging their duties with the German FH within ISAF until April 24, 2003. ${ }^{146}$

\footnotetext{
${ }^{146}$ http://www.army.cz/scripts/detail.php?id=6892
} 
The $6^{\text {th }}$ Field Hospital contingent, was relocated into the area of responsibilities in three phases. In the first stage, which begun on April 24, 2002, five members of a surgical company joined the $34^{\text {th }}$ British FH in Bagram. The second phased involved a logistic support group of 35 members that was sent to perform its duties in Kabul. Finally, an additional 110 personnel were deployed with equipment to Kabul. The contingent was mainly responsible for providing health care for ISAF personnel and humanitarian assistance for the local people. In mid-October 2002 , the $11^{\text {th }} \mathrm{FH}$ replaced the $6^{\text {th }} \mathrm{FH}$, and continued to carry out the same tasks until January $28,2003 .{ }^{147}$

Prague, in response to the request of the Allied Command Operations - SHAPE, to expand its commitment, increased its contribution to ISAF mission by installing a Field Hospital, and by sending chemical detachment and a group of military policeman. On the basis of the Czech government's decision, the development of a field medical facility started in March 2007, and is being prolonged in accordance with the government decisions. A Czech contingent is also deployed at the Kabul International Airport (KAIA). ${ }^{148}$ The $4^{\text {th }}$ Contingent of Armed Forces of the Czech Republic - Field Hospital and Chemical Detachment was established by 104 Czech and 7 Slovak soldiers and deployed for less than six months. The contingent carried out the following tasks: "Providing medical service to ISAF personnel; Transiting patients and preservation of their conditions prior to strategic evacuation; Forming of mobile teams in case of mass casualties to operate as far as 10 kilometers around the Kabul airport; Conducting preventive medical and veterinary care within the area of responsibility; Cooperating in education of medical personnel of the Afghan National Army and security forces". ${ }^{149}$ Additionally, starting from the end of April 2007, a 35-member Czech Military Police contingent of Special Operations Group (SOG) served in Helmand Province (in the south of Afghanistan). The detachment supplemented British brigade capabilities and guarded precise individuals and objects and facilities of critical importance. On the strength of the Czech government decision, the SOG mission ended in December 2008. The Czech Special Forces in the strength of 100 men had operated in Kandahar province under the US Command within the Operation Enduring Freedom in the years

\footnotetext{
${ }^{147}$ The people of Afghanistan were able to obtain health care at the hospital in Bagram, with the help of mobile medical groups and a temporary dispensary and also by possible access for selected patients from remaining hospital facilities through a combined effort with local Kabul medical institutions.

${ }^{148}$ The Czech contingent contained the following military personnel: Field Hospital Personnel (81), Chemical Detachment Personnel (8), Operational, Monitoring and Liaison Team (8), Meteo Service Personnel (4), Air Traffic Personnel (2), Military Police Personnel (3).

${ }^{149}$ The chemical detachment member staff is predisposed to take samples for ad hoc analysis and report HQ hence. In: http://www.army.cz/scripts/detail.php?id=12097
} 
2004 and 2006. The last deployment of 100 Czech Special Forces troops started in November 2008 and finished at the end of 2009. ${ }^{150}$

The Czechs also responded to the Dutch government request to increase the number of soldiers securing PRTs in Uruzgan province in southern Afghanistan. The Czech Prime Minister, Mirek Topolanek, declared that the proposed expansion in commitment was due to "growing responsibilities in the region and obligations to our allies in NATO". ${ }^{151}$ The governmental proposition to send additional troops to the Regional Command-South of ISAF was approved by both chambers of the Parliament for 2008, and for a further two months of 2009 by the Czech Government. The Czech Armed Forces' $2^{\text {nd }}$ contingent in the ISAF mission assumed operational tasks by January 16, 2009. The contingent executed a protection of the perimeter of the Dutch Camp Hadrian (Forward Operating Base Hadrian) which is situated close to the Deh Rawod town in Uruzgan province, southern Afghanistan. Detached Czech forces were deployed at the base together with up to 200 Dutch military personnel and soldiers of French Mountain Infantry (about 63 Czech soldiers - as of January 27,2009). The Czech contingent finished its mission in March 2009, and was replaced by Slovak armed forces. ${ }^{152}$

The Czech Armed Forces Task Force in ISAF is a new organizational unit formed in 2010, whose commander-in-chief directly supervises Czech troops stationed at the Kabul International Airport (KAIA) and provides administrative control over the remaining Czech armed groups serving in Afghanistan within the ISAF operation. The contingent stationed in Kabul continues, after reorganization, the work of previous deployments. The Task Force (TF) is composed of units under direct command of TF commander (Command and Staff, National Support Element, Military Police, Chemical and Biological Protection Unit, Air Mentoring Team (AMT) Unit ${ }^{153}, 1^{\text {st }}$ Field Surgical Team ${ }^{154}$, Representation at Kabul and Bagram Headquarters) and units under independent command (Provincional Reconstruction Teams at the Shank Base in the Logar Province, Helicopter Unit at

\footnotetext{
${ }^{150}$ http://www.centcom.mil/czech-republic/

${ }^{151}$ Hillison, New NATO Members, 31.

152 http://www.army.cz/scripts/detail.php?id=11293

${ }^{153}$ Air Mentoring Team - the main task of the unit is the training of Afghan airmen to pilot and maintain helicopters, both Mi-17 and Mi-24.

${ }^{154}$ Its four-month mission started on February 7, 2011. Prague sent this unit to reinforce the French Military Hospital at the KAIA.
} 
Sharana Base in the Paktika Province, Operational Mentoring and Liaison Team (OMLT) ${ }^{155}$, Training Team of the Czech Military Police in the Wardak Province). ${ }^{156}$

The Czech Republic runs its own Provincial Reconstruction Team in Logar province which comprises military and civilian parts. ${ }^{157}$ The Czechs participated for three years within the German PRT in Badakshan Province and since 19 March 2008 operates its own PRT in Logar Province, south of Kabul. Their main area of responsibilities was connected with providing security in the region, protecting international units, and working together with local inhabitants in reconstruction of the country. A A Czech contingent was attached to the crew of about 200 serviceman of PRT and served together with Danish and German soldiers. ${ }^{158}$ The Czech Republic also responded to the request of its allies to reinforce its military presence in Afghanistan to provide support in suppressing Taliban activities and assist the Afghan government. The Czech government and both chambers of the Czech Parliament authorized Armed Forces to commence their involvement in the operation for 2008, in November 2008 and approved its continuation in March 2009 for further deployment in 2010-2011. The newly appointed command of now the $7^{\text {th }}$ Unit of the Armed Forces of the Czech Republic to serve in assumed operational duties in February 19, 2011 and its soldiers carried out their duties for six months, until August 2011. ${ }^{159}$

The First Czech helicopter deployment within the ISAF operation in Afghanistan was in December 2009. The present deployment, $6^{\text {th }}$ unit of the Czech Armed Forces (ACR), is in service in Paktika Province as Task Force HIPPO and is part of the American Helicopter Task Force (FALCON). The $6^{\text {th }}$ ACR Unit is deployed at the US Forward Base Sharana in the Paktika Province and assumed operational tasks in May 2011, and served until August 2011. ${ }^{160}$ Both units, American and Czech,

\footnotetext{
${ }^{155}$ When the Czech unit finished a training phase that concentrated on the mentoring of Afghan "Kandak" personnel in Kabul, the unit was relocated to Wardak Province with a group of Afghans in December 2010 to carry out the tasks of the Afghan National Army (ANA) to take over in operational control of the designated area.

${ }^{156} \mathrm{http} / / /$ www.army.cz/scripts/detail.php?id=14355

${ }^{157}$ The Size of the $7^{\text {th }}$ ACR Unit serving within PRT Logar consists of 293 military personnel, and 11 civilian experts.

${ }^{158}$ Each Czech contingent performed its duties for six months, in the city of Feyzabad which lays in northeastern part of the country. In: http://www.centcom.mil/czech-republic/

${ }^{159} \mathrm{http} / / /$ www.army.cz/scripts/detail.php?id=39157

${ }^{160}$ The size of the unit constitutes for 99 personnel (including 21 air serviceman) and its major equipment is considered three upgraded Mil Mi-171S helicopters.
} 
carry out transportation assignments and observation duties on the side of commander of Regional Command East, RC-East. ${ }^{161}$

Prague has increased its contribution to the mission by sending an Operational Mentoring and Liaison Team (OMLT). The new training team, $1^{\text {st }}$ unit of OMLT, was deployed in September 2010. After a rotation, the commander of the present unit, $2^{\text {nd }}$ ACR OMLT, assumed control on April 22, 2011 from the commander of the previous unit. The headquarters of the Czech Operational Mentoring and Liaison Team is in Carwile Base in the southern part of the Wardak Province. The $2^{\text {nd }}$ OMLT of the Czech Republic Armed Forces unit consists of soldiers from seven units of the Czech Armed Forces, and in total currently 54 soldiers serve within the unit. The Czech OMLT comprises specialists (artillery and air controllers) who are able to fulfill specific tasks. The main area of responsibilities includes training, mentoring and helping an Afghan rifle battalion (Kandak) of the Afghan National Army (ANA) in the development of command and control. The aim of this particular training approach is to improve operational capabilities of all forces of the Kandak, which should help to create secure surroundings, set the conditions and protect the freedom of movement within the area of responsibility, and finally pave the way for further operations. Czech soldiers together with Afghan troops, and of course in cooperation with Americans, operate from three forward operational bases. Czech troops are fully equipped to be capable of independent activities within the given area. The 54-man unit also contains additional 15 command and staff officers. ${ }^{162}$

The number of Czech Armed Forces serving in Afghanistan, valid as of $26^{\text {th }}$ August 2011, was 620 troops.

\subsubsection{Hungary}

Since 2003, Hungary's contribution to ISAF mission has been continuously growing and in doing so, Budapest proves that is not a recipient of common security but advances it in NATO, and indirectly in the EU as well. ${ }^{163}$ In the early October 2006, Hungary took over control of the Baghlan PRT from the

\footnotetext{
${ }^{161}$ http://www.army.cz/scripts/detail.php?id=44697

${ }^{162}$ http://www.army.cz/scripts/detail.php?id=47174

${ }^{163} \mathrm{http}: / /$ www.mfa.gov.hu/kum/en/bal/foreign_policy/security_policy/hungary_in_nato/hungary_role_in_afgh anistan/
} 
Netherlands. ${ }^{164}$ The Hungarian Provincial Reconstruction Team came into existence on the strength of the governmental decree of June 2006, and increased the country's involvement to a higher level and augmented it with development activities. ${ }^{165}$ The Hungarian PRT comprises several old, new and, at that time, future EU member countries who help to fulfill development plans.

In 2007 the European Union established a police training operation (EUPOL) to which Hungary willingly contributed. Hungary's Ministry of Justice and Law Enforcement delegated 5 staff members to the EU operation and in the meantime carried out varied activities in support of the training of the Afghan police forces. ${ }^{166}$

In order to supervise more efficiently PRTs, Hungary decided to set up a Government Coordination Committee (GCC) at the ministerial level on February 20, 2008, which improved the government coordination and decision-making process. Both the Minister of Foreign Affairs and the Minister of Defense hold co-chair positions in the newly set-up Committee. ${ }^{167}$ The GCC assembles four times per year in a body with delegates of all relevant ministries. ${ }^{168}$ With reference to the military aspect of the PRT, the GCC is not competent to amplify a military strategy or to specify military goals. ${ }^{169}$

164 Baghlan Province is situated on the northern slopes of the Hindu Kush Mountains. The Province has around 800,000 inhabitants which consists of a heterogeneous population of Hazaras, Pashtuns, Uzbeks and Tajiks who represent the largest ethnic group (over $50 \%$ of the population). Pusthuns presents approximately $20 \%$ of Baghlan total population; however, they make up majority in the Baghlan Jadid, Dahan-e Ghori and Burqa areas. In the 1980s this territory was controlled by the Hizb-e Islami (Gulbuddin) and with the encroachment of the Taliban, it was taken over by them in 1997. Under Taliban authority the Baghlan Jadid city was the capital.

165 The preceding command was created in 2004 and on the strength of a two-year mandate conducted development works and supported and built up the authority of the Afghan Government.

${ }^{166}$ http://www.mfa.gov.hu/kum/en/bal/foreign_policy/security_policy/hungary_in_nato/hungary_role_in_afgh anistan/

${ }^{167}$ The GCC contains other members, including the finance minister, the head of the Office of Prime Minister, Minister of Justice and Law Enforcement and Minister of National Development and Economy, http://www.mfa.gov.hu/kum/en/bal/foreign_policy/security_policy/hungary_in_nato/hungary_role_in_afghan istan/

${ }^{168}$ According to Peter Wagner, unfortunately none of the Hungarian NGOs which are active in Afghanistan, have never been requested to participate in these assemblies to discuss their activities and their views about the efficiency of the PRT.

169 Peter Wagner, The Background of the Hungarian Activities in Baghlan. Hungarian Institute of Foreign Affairs. Policy Brief, Feburary 15, 2010, http://www.kulugyiintezet.hu/pub/displ.asp?id=NBWWAE 
In 2008 about 210 staff including members of the Hungarian armed forces carried out a number of tasks in addition to military duties, including development of the living conditions of the Afghan people and greater effort on finishing projects whose aim was to provide a groundwork for infrastructural developments as part of civil-military co-operation (CIMIC). Civil development tasks are carried out mainly through expert ministries and non-governmental organizations and are channeled to Baghlan province and local population needs. Simultaneously they are connected to goals attached within the Afghan National Development Strategy (ANDS). The idea of development is to create sufficient conditions for the Afghan state's self-sustaining economy through job creation, establishing a constitutional state, educational institutions and non-drug agricultural economy. This approach is guided by the implementation of projects involving local workers and deliveries to a large extent. $^{170}$

Hungary increased its troop presence in Afghanistan by 200 in 2010, which extended total number of personnel to 500 within the ISAF mission (it constitutes half of the total number of Hungarian Defense Forces (HDF) military staff in missions abroad). Additionally, besides the "traditional" missions on Afghan soil, Hungarian military forces shouldered new duties in the region in 2010. The Mi-35 Mentor Team stationed in Afghanistan for the first time was obliged to coach the attack helicopter pilots in the Afghan National Army Air Force (ANAAF). Moreover, a Hungarian Defense Forces Combat Service Support (CSS) and Engineer Mentor Team embarked on training the armed forces of the newAfghan National Army (ANA). The expanded area of activities and substantial military surge required the stationing of a National Support Element (NSE) in the area which controls and provides logistics infrastructure. In September 2010, HDF retook command of the Kabul International Airport, where eighty Hungarian soldiers hold diverse position under Brig-Gen. Nandor Kilian. In the region is also stationed Hungarian Special Operations Task Group (SOTG), which is deployed in fourth-month rotations and joins the American Special Forces in special operation tasks. The Operational Mentoring and Liaison Team (OMLT) prolonged it active service in Khilagay, where the OMLT together with the Ohio National Guard advises and trains an ANA battalion. ${ }^{171}$

In addition, in 2010 there occurred a change in the most developed contingent - the Hungarian Defense Forces Provincial Reconstruction Team (HUN PRT). The decay of security and the increased

\footnotetext{
${ }^{170} \mathrm{http}: / /$ www.mfa.gov.hu/kum/en/bal/foreign_policy/security_policy/hungary_in_nato/hungary_role_in_afgh anistan/

171 Szabo Bela, Increasing Role. Hungarian Defense, January 18, 2011, http://www.hungariandefence.com/cikk/23875/increasing-role
} 
number of assaults on international forces resulted in the unfeasibility of the HUN PRT to fully execute its assistantance to reconstruction tasks, thus the Hungarian Defense Forces Joint Forces Command had to rethink its forthcoming engagement. Perhaps, HUN PRT will still make training and mentoring tasks as their focal point of commitment to the mission. ${ }^{172}$

As of $16^{\text {th }}$ August, 2011, was 433 Hungarians were serving in Afghanistan.

\subsubsection{Poland}

With the largest population of V4 countries and central role in the Iraqi mission, Poland was expected to provide valuable contributions within International Security Assistance Force mission in Afghanistan. However, at the beginning for an anti-terrorist "Enduring Freedom" operation, in total, Poland designated a military contingent numbering of 300 soldiers. ${ }^{173}$ At the beginning of January 2002, the Polish Military Contingent (PKW) had reached combat readiness, and its direct involvement in Afghanistan occured in March 2002, when to the area of activities was redeployed a group of 87 soldiers (sappers, logistics, commandos from Polish special forces GROM) and around 500 tons of military equipment. In practice in Afghanistan within "Enduring Freedom" a group of only 100 soldiers were in continued operation (mostly company of sappers, and also logistic and security component), equipped with heavy equipment. They were stationed at the Bagram base below Kabul, where they have been stationed until now. Their main tasks include cleaning the terrain around the base and airport in Bagram of mines, development of fortifications and infrastructure of the base, and also distribution of fuels and water for coalition forces. Additionally, as was already mentioned, from July 2002 to September 2003, to help control traffic in the Arab Sea area, the warship "Rear Admiral Xawery Czernicki" was deployed. Remaining groups of soldiers in the Polish Military Contingent (PKW) were not counted in these activities. The time of PKW operating within antiterrorist operation was initially estimated for half year. To make possible the further activity of the contingent, the President of Poland issued on 24 June 2002 another statement which prolonged the

\footnotetext{
${ }^{172}$ Ibid.

${ }^{173}$ The Polish Military Contingent (PKW) takes part in the operation on the legal basis of the President of Poland's decision from November 22, 2001, to use PKW within Coalition Forces operating in Afghanistan, the Tajikistan Republic, the Uzbek Republic and also on the Arab Sea and the Indian Ocean. In regard to two new amendments to this legal instrument, the territorial operational range of PKW was expanded initially on to the Kirghiz Republic area, and later to the Bahrain Emirate and Kuwait. The initial composition of the PKW included: Commando unit GROM ; 1. Sapper Brigade from Brzeg (a sapper platoon) ; 10. Logistic Brigade from Opole (a logistic platoon) ; 4. Chemical Regiment from Brodnica (an anti-chemical platoon) ; Bacteriological reconnaissance team (Wojskowy Instytut Higieny I Epimediologii w Puławach specialists); Logistical back-up warship sailors ("Rear admiral Xawery Czernicki”), See Winid, Udział Polski w Działaniach Stabilizacyjnych, 6
} 
PKW mandate to the end of 2002, and again on 23 December 2002, until the end of 2003. The area of activity and size of the contingent did not change. ${ }^{174}$

In the statement of the President of Poland from December 29, 2003 about using the Polish Military Contingent on Afghan soil, the numerical strength went down to 120 soldiers, and its area of operation was limited only to Afghanistan. This decision was related to the considerable engagement of Polish military forces in Iraq, where on September 2003 they took command over Multinational Division Centre-South, and deployed to the mission area a contingent of 2500 soldiers. De facto limits did not influence seriously the direct Polish commitment to the operation in Afghanistan, because since the beginning of participation of PKW in the Enduring Freedom Operation, the numerical strength of the Polish contingent in the area of activities did not exceed the number of 100 soldiers. Particularly important from the statement for 2003 was, after all, the extent of PKW involvment. It had ceased to be solely devoted to Enduring Freedom, because now part of it was also to be deployed to undertake actions with the ISAF operation. Poland joined ISAF in a symbolic way by sending in February 2004 two officers (Kabul airport service). ${ }^{175}$

The Polish Military Contingent, in principle, limited its activities to the field of engineering until the beginning of 2007. ${ }^{176}$ Plans of Polish engagement in Afghanistan were formulated anew as a result of NATO's decision about a change in the command operation system. On 6 April 2006 the NATO Military Committee decided to resign from a command based on the current corps' model and approved a memorandum on the transformation of ISAF command in accordance with composite model (constant structure of NATO command, filled by member countries in connection with their commitment to the mission - how many people are involved). ${ }^{177}$

Polish engagement in the mission has increased starting in September 2006. On 23 May of that year The Council of Ministries agreed to the enlargement of the Polish Military Contingent's numerical strength in Afghanistan beginning 1 September 2006, from 120 to 190 soldiers and military staff by allotting extra personnel to ISAF forces - the Provincial Reconstruction Team in Mazar-e-Sharif and to the Regional ISAF command. On 30 August 2006 the President of Poland signed an appropriate

\footnotetext{
174 Ibid., 7.

175 Ibid., 7.

${ }^{176}$ http://www.isaf.wp.mil.pl/pl/15.html

${ }^{177}$ Winid, Udział Polski w Działaniach Stabilizacyjnych, 8.
} 
resolution from the Council of Ministries in this regard. Next, on 22 November of that year, the President of Poland announced another resolution which increased PKW personnel to 1200 soldiers. ${ }^{178}$

On February 3, 2005 in Szczecin, during the meeting of defense department chiefs of Poland, Denmark and Germany - countries contributing to the command of Multinational North-East Corp declared their readiness to take command over the XI shift of operation ISAF (from August 2007 to February 2008). In accordance to NATO's decision of 9 February 2005, the corps' command was attached to the rotation plan of ISAF command. At that time they assumed that taking command over ISAF by the Szczecin group would increase number of PKW troops in Afghanistan from August 2007 to February 2008, by no more than 1000 soldiers. ${ }^{179}$

This issue was discussed during the session of the Council of Ministers. It authorized on 23 August 2005 the Minister of National Defense to undertake with Ministry of Foreign Affairs preparatory work in anticipation of the further commitment of Poland army in operation ISAF in Afghanistan, in fulfilling to Poland's obligation towards NATO. ${ }^{180}$

The Polish presence in Afghanistan was strengthened by deploying to the region a maneuver battalion. The organizational scheme of Polish Military Contingent in Afghanistan has changed since November, 2008. The newly established Polish Task Force White Eagle, which was one of the Brigade Battle Groups in Regional Command-East, took over responsibility for security and training of the Afghan security forces in the Ghazni Province. The Polish contingent is deployed in five major bases in the province: Ghazni, Warrior, Giro, Vulcan, Qarabagh and also in the coalition forces base in Bagram. Since 2010, Polish Task Force White Eagle was supported by American infantry battalion, what allowed it to conduct operations more efficiently in Ghazni province. American Battalion Combat Groups is the third subdivision, next to combat groups Alfa and Bravo, reporting directly to the commander of the Polish Task Force. ${ }^{181}$ In 2008 an American-Polish PRT was also established in the Ghazni province. ${ }^{182}$

\footnotetext{
${ }^{178}$ Ibid., 8.

${ }^{179}$ Ibid., 8.

${ }^{180}$ Ibid., 8.

${ }^{181}$ http://www.isaf.wp.mil.pl/pl/15.html

${ }^{182}$ http://www.isaf.wp.mil.pl/pl/113.html
} 
Starting from 1 April, 2009, more than 70 Polish soldiers carried out responsibilities at Kabul Afghanistan International Airport (KAIA). KAIA group ended its mission on 1 October, 2009. During that time Polish soldiers protected in total 56288 air operations. Polish personnel filled a majority of the key posts in KAIA, as a commanding post, the chief of staff I and the chief of logistics in KAIA, which had important significance for governance and efficient functioning of the airport. Poles took responsibility over civilian and military air operations in the air and on the airfield, coordination of air traffic, as well as key staff structures and elements of back-up and security. The Polish sapper group was responsible for detecting and disarming unexploded bombs and other hazardous materials threatening the security of air operations and the safety of KAIA personnel. ${ }^{183}$

The above information demonstrates that Polish engagement until 2007 in Afghanistan was rather minimal. Enlargements of PKW since 2007 gradually strengthened the position of Poland in the Alliance, and the present deployment of Polish forces in the ISAF mission is 2579 soldiers and ranks as the fifth largest. ${ }^{184}$

\subsubsection{Slovakia}

In comparison to all remaining V4 countries, Slovakia has provided the leastt support to Operation Enduring Freedom and International Security Assistance Force mission in Afghanistan. However, this small Central European nation has still contributed a helpful level of forces for the ISAF operation, in spite of governmental change (socialists critical of Slovakia's participation came to power) and later the global financial crisis. During Operation Enduring Freedom, in 2002, Slovakia deployed Air Engineer Company (AEC - 40 soldiers) at Baghram to carry out the rebuilding of the airfield in this province. ${ }^{185}$ Initially, in 2005 , Slovak government had decided to deploy troops to be part of the ISAF operation to engage in the provision of airport security. Air Engineer Company was relocated in 2005 from Baghram to Kabul to operate under NATO's ISAF mission. Another Engineer Company (17 troops) which operated under ISAF was stationed in June 2004 as part of a de-mining unit at the international airport in Kabul (KAIA). In December 2006, Engineer Company and Air Engineer Company were transferred into a Multi-Purpose Engineering Unit - SLOVCON (57 soldiers) to help

\footnotetext{
${ }^{183}$ http://www.isaf.wp.mil.pl/pl/6.html

${ }^{184}$ Winid, Udział Polski w Działaniach Stabilizacyjnych, 13.

${ }^{185}$ http://www.centcom.mil/slovak-republic/
} 
fulfill ISAF tasks within the NATO mission. As determined by NATO headquarters, SLOVCON was relocated in May 2007 from KAIA to KANDAHAR AIRFIELD (KAF). The main tasks of SLOVCON include the rebuilding of facilities of KAF and the demining and maintaince of areas and roads in the area of the internal perimeter of base. ${ }^{186}$ The implementation of demining operations is a key part of the constant expansion and reconstruction of base facilities. ${ }^{187}$

With respect to the ISAF mission in Afghanistan, the Slovak government in October 2007, and the Parliament in December 2008 decided to prolong the missions of the engineering contingent of Slovak Armed Forces at Kandahar Airfield and to deploy 5 servicemen to Provincial Reconstruction Teams, 5 serviceman to Operational Mentor and Liaison Team, 8 serviceman to the Field Hospital at Kabul Airport (April-October 2008), 5 serviceman to the ISAF's command posts and deployment of a guard unit of 35 troops. Thus in 2009 the total number of Slovak military staff performing duties within the ISAF mission reached a number of 155 personnel. ${ }^{188}$ The new reinforcements operated closely with contingents from the Netherlands and the neighboring Czech Republic. Slovak forces within the PRT in Tarin Kowt are involved in the construction and development of Uruzgan province through the development of local infrastructure and implementation of various projects. The Provincial Reconstruction Team is generally a significant part in developing a secure and stable environment in Afghanistan. ${ }^{189}$

Officers from the Operational Mentor and Liaison Team in Tarin Kowt, Uruzgan province, conduct ongoing training for units of the Afghan National Army (ANA), and monitor and supervise the implementation of daily activities. Members of the Armed Forces operate in the Dutch OMLT as instructors in planning and operations management, logistics, personnel and health care. They interact directly with the ANA units to assist in carrying out their operations, including deployment in the field. ${ }^{190}$

\footnotetext{
${ }^{186} \mathrm{http} / / /$ www.mod.gov.sk/330/operacia-isaf-afganistan.php?mnu=181

${ }^{187}$ Slovak soldiers carry out tasks on sections of the former Russian air base terrain. Among other tasks, the company meets the requirements of Engineer-airport and construction work. It is mainly the repair of unpaved roads, construction of minor road construction, reconstruction, repair of airfields, tasks associated with the protection of live forces as well as various types of earthworks. In: http://www.mod.gov.sk/330/operacia-isafafganistan.php?mnu=181

${ }^{188}$ http://www.centcom.mil/slovak-republic/

${ }^{189}$ http://www.mod.gov.sk/330/operacia-isaf-afganistan.php?mnu=181

${ }^{190}$ Ibid.
} 
Guard units on bases in Kandahar and Tarin Kowt patrol assigned sections of the internal perimeter bases, protect and defend the assigned objects, and carry out physical checks on persons and vehicles within essential I / O points. Slovak patrol units are an important part of the basic forces of NATO. Officers patrolling units operate in extreme climatic conditions, and face the constant threat of indirect (rocket and mortar attacks) and suicide attacks. They are in constant close contact with local populations in different environments and hygiene practices, which enhance the spread of contagious diseases (especially malaria, hepatitis and tuberculosis). An important task of patrolling units is its approach to local communities to shape a favorable public opinion in relation to the ISAF mission and thus contribute to the achievement of the entire mission. ${ }^{191}$

EOD team tasks include detection, identification, evaluation of the situation and possible threats, and to neutralize and ensure deliverance and final disposal of unexploded explosive devices. Up to 6 members of the Armed Forces are working in a variety of desk positions within the ISAF headquarters and the Regional Command South - RC (S). The National Support Element (NSE) coordinates national security and logistical support units, individuals, and members of the Armed Forces deployed in ISAF. NSE provides, among other things, evaluation of the performance of personnel activities, administrative support and funding for the Armed Forces contribution to ISAF. Slovak Republic as a NATO member state accedes to the ISAF operation with appropriate responsibilities. Its aim is to achieve the objectives declared at the NATO summit in Bucharest to increase the representation of its Armed Forces of the operation and promote a comprehensive approach by the international community to Afghanistan.

Bratislava has decided to contribute to the international effort and increase the Slovak presence in Afghanistan, being aware that ISAF's mission is crucial for NATO. The decision of additional commitment demonstrated that Slovakia as a reliable and responsible NATO member. The Slovak Government at that time intended to intensify its commitment with greater manpower in the next year, and planned to deploy in 2009-2010 new forces to reach a total number of troops of around 250-280 soldiers. ${ }^{192}$ The resolution of the National Council of 3 February 2010 approved an increase in the mandate of ISAF to 319 members of the Armed Forces of National Council and a resolution of 7

\footnotetext{
191 Ibid

${ }^{192}$ http://www.centcom.mil/slovak-republic/
} 
December 2010 to 348 members of the Armed Forces. As of 16 August, 2011, under the ISAF mission there were 309 members of the Slovak armed forces. ${ }^{193}$

19312 members serving in the ISAF headquarters (HQ ISAF IJC, RC-S, KAF and PALADIN); 16 members of the Slovak contingent headquarters and the national support element in the area of Kandahar air base ; 57 man in multifunctional engineer company ; 2 members of the PRT in Tarin Kowt (Uruzgan province) ; 15 members of OMLT ; 53 members of the unit guarding the forward operating base in Tarin Kowt ; 164 members of the guard unit at an air base in Kandahar ; 4 members of the pyrotechnic team (EOD TF PALADIN-S) 


\section{Experiences from the Afghan Mission - How CEC are Perceived by NATO and the USA and What Have They Gained from the Mission?}

In his publication, "New NATO Members: Security Consumers or Producers?", Joel R. Hillison analyzes new NATO member countries engagement in the context of burden-sharing within the Alliance. The "burden-sharing responsibility" in his monograph is defined as "the distribution of costs and risks among members of a group in the process of accomplishing a common goal" and its complexity is examined from a collective action perspective. Countries which do not contribute to the realization of the collective goal were simply described as a free riders. ${ }^{194}$

Hillison emphasizes that in the ISAF mission (and especially in the case of Poland in the U.S.-led operation Iraqi Freedom) the new member contribution from the V4 group equaled or even exceeded those of similarly sized older Alliance members. In addition, V4 countries' contributions were qualitatively distinct from particular older members in that the Central European armed forces had few, if any, national caveats. The increased contribution to NATO's missions by V4 countries over time indicates that earlier deficits caused rather by a shortage of capability than a calculated freeriding attitude. As Visegrad group member combat capabilities and levels of interoperability developed, Central European nations become more willing and competent to take on additional tasks. ${ }^{195}$

Hillison's approach in the examination of new NATO members as security consumers or producers encouraged me to undertake a similar study of particular V4 countries' contribution to the ISAF mission by comparing them to all remaining NATO members. The analysis undertaken in this chapter proves that the contributions of NATO members to the ISAF mission varies considerably from country to country, and in the case of V4 member countries, the same features are visible. In this regard, the real aim of this examination will be also to answer whether the V4 countries' commitment to the ISAF mission has been acknowledged by NATO and the USA as a adequate to their military and economy potential or instead estimated as free-riding behavior. Finally, the last part of this chapter will be devoted to the examination of the American - Central European relationship in the context of

\footnotetext{
${ }^{194}$ Hillison, New NATO Members, v.

195 Ibid., vii.
} 
the NATO mission in Afghanistan and the changes in American and Central European countries' foreign policy agendas.

\subsection{The Evaluation of the CEC commitment by NATO and USA.}

For V4 countries 2011 marked the eighth year of their deployment in Afghanistan. Central European countries also participated in other operations during the same period (for example, active Polish participation in Iraqi mission). Due these "over-stretched" activities and the resulting costs in blood and higher expenditures, the political elite and public opinion in member countries became war weary.

NATO's ISAF operation in Afghanistan is the first "out-of-area" mission when the alliance members' forces were deployed beyond Europe. NATO, although it had already led stabilization and reconstruction missions, the area of assigned responsibilities in Afghanistan is substantially more difficult. There are several factors making this mission more fragile, than for example, the stabilization mission in Kosovo: the stiff resistance of Taliban and al-Qaeda insurgents, Afghanistan's terrain, the distance from Europe, and the fact that Afghanistan has never been a state in a western sense with a well-functioning central government. Furthermore, the ISAF stabilization mission and reconstruction of the country are being attempted while combat operations proceed. And last but not least, even though NATO members have agreed upon the general goals of the operation, there are still differences of how to accomplish them. ${ }^{196}$

The burden-sharing debates have been a constant feature in the agenda of NATO, but recently they have become more tempestuous as the United States found itself over-stretched in both, Afghanistan and Iraq, and faced budgetary problems due to the global economic crisis. ${ }^{197}$ NATO's ISAF stabilization mission in Afghanistan embodies perfect conditions for free-riding behavior to be present. For NATO it is the first peacekeeping mission outside of Europe. Within this mission, Washington and London's priority was not to get drawn into stabilitization and reconstruction efforts, which in turn was regarded with skepticism by continental allies, who instead demanded accentuation of stabilization and reconstruction tasks for international forces. The Bonn Agreement

\footnotetext{
${ }^{196}$ Morelli and Belkin. NATO in Afghanistan, 4.

${ }^{197}$ Hillison, New NATO Members, V.
} 
was a solution which envisaged a mix of both approaches. ${ }^{198}$ The core of the ISAF mission involves stability and reconstructions tasks, but NATO forces are to a greater or lesser extent preoccupied in combat operations which depend upon the location of the contingents and national caveats established by particular governments. ${ }^{199}$ In this regard the evaluation of the CEC commitment by the USA and NATO should be examined from two perspectives - by assesing the effectiveness of engagement in stabilization and reconstruction tasks, and also in combat operations.

\subsubsection{V4 Countries Troop Contributions}

Politically, the conduct of the ISAF mission become a leading factor which could influence NATO's future. Major Alliance countries view the mission as a test case for the member countries' capabilities and will to oppose existing threats to their security. However, from year to year opposition to the NATO mission in Afghanistan grew among the public in Europe. According to many experts' declarations, considerable improvement in stabilizing and reconstructing Afghanistan had to completed in 2010, otherwise NATO's internal solidarity in support of NATO mission could be substantially and harmfully undermined. ${ }^{200}$ One of the factors in examining the political will of V4 countries is their troop contributions to the ISAF mission, which also expresses allied solidarity of burden-sharing responsibility. Furthermore, some NATO members claim also that the military commitment is paramount for security improvement and efficient reconstruction of Afghanistan. ${ }^{201}$

Since the beginning of the ISAF mission, NATO leaders have experienced an inadequate number of allied troops in Afghanistan. At the NATO Summit in Bucharest in April 2008, key members of NATO with combat contingents tried to persuade other allies to send more troops for the ISAF mission. While NATO members stated their "strategic vision" for Afghanistan and agreed to a shared longterm engagement, they did not guaranteed their willingness to contribute a proportionate share of combat troops. This can be attributed to NATO's own budget rules - when an allied country agrees to deploy forces to a operation, that nation is responsible for the costs related to that deployment. Therefore, this incentive factor limits allies willingness to commit any contingents to a operation or

\footnotetext{
${ }^{198}$ Noetzel and Scheipers. Coalition Warfare in Afghanistan, 3.

${ }^{199}$ Hillison, New NATO Members, 27.

${ }^{200}$ Morelli and Belkin. NATO in Afghanistan, 4-5.

${ }^{201}$ lbid., 7.
} 
to an additional deployment of troops. This problem becomes even more complicated in countries with fragile governments or coalition governments, when political leaders have to convince their legislatures and opinion polls to support deployment of national troops abroad. While the security situation has been continuously deteriorating, NATO and the United States' military leaders were conducting a number of various strategy reviews. One of the identified solutions to counter the deterioration of the security situation in Afghanistan was to send additional troops to that country. The outgoing American President, George W. Bush, in 2008 undertook the first steps to increase additional U.S. forces in Afghanistan. However, the American effort to increase considerably its forces was not considered substantial until the incoming Obama administration committed additional troops in large numbers. Shortly after Obama assumed his presidency, he made an effort to encourage American allies to contribute additional forces and equipment to the ISAF mission. Initial reactions in European countries were not promising; nevertheless their contributions have gradually increased. ${ }^{202}$

The reluctance of the NATO members to deploy troops on Afghan soil has been driven partly by the opposition of Europeans who after many years have not seen significant progress of the ISAF operation, and partly by budget realities during a hard time of global economic crisis which has impacted the budgets of many nations. ${ }^{203}$

\subsubsection{In Comparison to Older NATO Members}

By 16 August 2011, ISAF had an estimated 130,697 troops from 48 troop contributing nations, with the 28 NATO members providing the core of the forces $(126,230)$. The largest troop deployments in Afghanistan were from the United States which had about 90,000 troops, the United Kingdom 9,500, Germany 5,000, Italy 3,974, France 3,939, Poland 2,579, Romania 1,949, Turkey 1,840, Spain 1,523 and Australia $1,550 .{ }^{204}$

For the purposes of this study, I will focus on the V4 contribution to the mission after ISAF had expanded to the east and NATO took responsibility for the entire country. Thus, the comparison will comprise particularly the years from 2007 to 2011 . To be able to judge the relative contribution of V4

\footnotetext{
202 Ibid., 22-23.

203 Ibid., 22.

${ }^{204}$ http://www.isaf.nato.int/troop-numbers-and-contributions/index.php
} 
countries to the NATO ISAF mission it is necessary to compare the national contributions as a percentage of NATO force versus a particular nation's population as a percentage of NATO's total population. Therefore I will use this approach to evaluate V4 countries' contribution. ${ }^{205}$ To begin with, it is necessary to provide basic information on the V4 countries' population and their percentage of the NATO population.

Table 1: Visegrad Group Member Countries' Population as a Percentage of NATO and European NATO Members' Population

\begin{tabular}{|c|c|c|c|}
\hline $\begin{array}{l}\text { Country / } \\
\text { Organisation }\end{array}$ & Population & $\begin{array}{c}\text { Percentage of NATO } \\
\text { population }\end{array}$ & $\begin{array}{l}\text { Percentage of European } \\
\text { NATO members' } \\
\text { population }\end{array}$ \\
\hline Czech Republic & 10190213 & $1.12 \%$ & $1.80 \%$ \\
\hline Hungary & 9976062 & $1.09 \%$ & $1.76 \%$ \\
\hline Poland & 38441588 & $4.21 \%$ & $6.80 \%$ \\
\hline Slovakia & 5477038 & $0.60 \%$ & $0.97 \%$ \\
\hline V4 & 64084901 & $7.02 \%$ & $11.33 \%$ \\
\hline NATO population & \multicolumn{3}{|c|}{912722104} \\
\hline $\begin{array}{l}\text { Europe NATO } \\
\text { population }\end{array}$ & \multicolumn{3}{|c|}{565459471} \\
\hline $\begin{array}{l}\text { Europe ISAF } \\
\text { population }\end{array}$ & \multicolumn{3}{|c|}{668757893} \\
\hline
\end{tabular}

Source: Personal calculations based on CIA World Factbook and ISAF mission website (valid as of 16 August 2011).

As we can see in the Table 1, the Czech Republic comprises 1.12\%, Hungary $1.09 \%$, Poland $4.21 \%$ and Slovakia $0.60 \%$ of the NATO total population (all V4 countries together comprise $7.02 \%$ of NATO's population). In the first year after NATO seized a responsibility over the whole Afghan territory (data from 2007), the V4 troop contributions comprised approximately $1.45 \%$ of the total NATO force in Afghanistan and $2.99 \%$ of the total NATO's European members contribution (accordingly $3.12 \%$ and $10.42 \%$ in 2011) - see Tables 2 and $4 .^{206}$

\footnotetext{
${ }^{205}$ Hillison, New NATO Members, 4.

${ }^{206}$ http://www.isaf.nato.int/troop-numbers-and-contributions/index.php
} 
Table 2: Visegrad Group Member Countries contribution to the ISAF Mission as a Percentage of NATO's Total Troops within the ISAF Mission in Afghanistan.

\begin{tabular}{|l|c|c|c|c|c|}
\hline \multicolumn{1}{|c|}{ Country } & $\begin{array}{c}\text { Percentage of } \\
\text { NATO total } \\
\text { population }\end{array}$ & $\begin{array}{c}\text { Troops } \\
\text { contribution in } \\
2007\end{array}$ & $\begin{array}{c}\text { Percentage of } \\
\text { NATO total } \\
\text { troops in 2007 }\end{array}$ & $\begin{array}{c}\text { Troops } \\
\text { contribution } \\
\text { in 2011 }\end{array}$ & $\begin{array}{c}\text { Percentage of } \\
\text { NATO total } \\
\text { troops in 2011 }\end{array}$ \\
\hline $\begin{array}{l}\text { Czech } \\
\text { Republic }\end{array}$ & $1.12 \%$ & 150 & $0.43 \%$ & 620 & $0.49 \%$ \\
\hline Hungary & $1.09 \%$ & 180 & $0,52 \%$ & 433 & $0.34 \%$ \\
\hline Poland & $4.21 \%$ & 160 & $0.46 \%$ & 2579 & $2.04 \%$ \\
\hline Slovakia & $0.60 \%$ & 60 & $0.17 \%$ & 309 & $0.24 \%$ \\
\hline V4 & $7.02 \%$ & 550 & $1.45 \%$ & 3941 & $3.12 \%$ \\
\hline
\end{tabular}

Source: Personal calculations based on CIA World Factbook and ISAF mission website (valid as of 16 August 2011).

As shown above we can notice that the contributions of the V4 countries were constantly below their proportion of the total NATO population before and after NATO took responsibility over the whole of Afghanistan. On the other hand, if we compare V4 countries' contribution to the European members' of this organization, the figures become more respectable, almost meeting the demanded level of contribution (the lack of contribution in the years before 2007 was due to the fact some of the V4 countries were constrained by their participation in the Operation Iraqi Freedom, OIF). ${ }^{207}$

Yet to understand why individual V4 countries' troop contributions to the ISAF mission did not reach a level similar to their percentage of NATO population (although they have substantially increased their level of contribution since 2007), it is necessary to look at the United States' considerable growth of troops in Afghanistan. The United States' troop level had grown significantly over time, but it was not until 2009 that with the change of administration it began to grow even more substantially and rapidly. The combination of low international troops' contribution and imposed national caveats

\footnotetext{
${ }^{207}$ The Czech Republic deployed 300 troops to OIF in 2003, while Belgium comparable in size, did not send any troops. Hungary deployed 500 troops to OIF in 2003 and nearly 290 in 2004 and 2005, before they finally withdrew its contingent. Poland's participation in ISAF was also constrained by engagement to OIF. Poland had committed one of the largest contingents to the Iraqi mission, deploying at it start over 2000 troops and ending the mission under the Multinational Forces with about 900 soldiers in 2008. Furthermore, Warsaw also played a leading role in the multinational sector in Iraq. At America's request, the Polish government twice delayed its contingent's withdrawal from Iraq. They finally withdraw troops in 2008, after the parliamentary elections were won by the Civic Platform Party in 2007. In: Hillison, New NATO Members, 31-33
} 
enabled Afghan insurgents to reemerge and forced Americans to nearly double their troops' presence in 2009 and to reach the level of a 90,000 men strong deployment in 2011 (see Table 3).

Table 3: The Growth of American Military Troop Contribution since 2007 Within the ISAF Mission

\begin{tabular}{|c|c|c|c|}
\hline Country & 2007 & 2011 & \% growth \\
\hline The United States & 14000 & 90000 & $643 \%$ \\
\hline
\end{tabular}

Source: Personal calculations based on CIA World Factbook and ISAF mission website (valid as of 16 August 2011).

Therefore we can observe that the small increase in the percentage of the total NATO force contributed by the V4 countries can be attributed simply to the striking increase in American contributions, which in fact grew by over $643 \%$ from 2007 to 2011 (from 14,000 to 90,000 troops).

Undoubtedly, Europe will be always overshadowed by Americans in Afghanistan and South Asia, without any need for elaboration because of the enormous differences in military potential. For that reason a more accurate analysis should correspond with the comparison of V4 nations' percentage of the European NATO population to the percentage of their troops contribution as a percentage of the European allies' troops in Afghanistan.

As of August 2011, the entire NATO's European members' contribution to the mission constituted less than a third (about 28\%) of the total number of combat troops in Afghanistan and their civilian presence is still minimal in comparison to Washington's presence with thousands of experts and troops deployed there. Nevertheless, the majority of the European states have engaged more armed forces in Afghanistan than in any modern area of conflict since the initiation of the European security and defense policy in 1999 (in total in 2011, 37,816 troops served from the participating European countries). ${ }^{208}$ For example, Germany, had deployed the largest number of its troops abroad since the Second World War.

\footnotetext{
${ }^{208}$ Fabrice Pothier, Europe: Loosing and at a Loss ? Brussels: Carnegie Endowment for International Peace, November 9, 2009; http://carnegieeurope.eu/publications/?fa=24115.
} 
Table 4: Visegrad Group Member Countries' Troop Contributions as a Percentage of NATO's European Members Troop Contributions to the ISAF mission

\begin{tabular}{|l|c|c|c|c|c|}
\hline \multicolumn{1}{|c|}{ Country } & $\begin{array}{c}\text { Percentage of } \\
\text { total European } \\
\text { NATO members' } \\
\text { population }\end{array}$ & $\begin{array}{c}\text { Troops } \\
\text { contribution } \\
\text { in } 2007\end{array}$ & $\begin{array}{c}\text { Percentage of } \\
\text { total European } \\
\text { NATO } \\
\text { members' } \\
\text { troops in 2007 }\end{array}$ & $\begin{array}{c}\text { Troops } \\
\text { contribution } \\
\text { in } 2011\end{array}$ & $\begin{array}{c}\text { Percentage of } \\
\text { total European } \\
\text { NATO members' } \\
\text { troops in 2011 }\end{array}$ \\
\hline $\begin{array}{l}\text { Czech } \\
\text { Republic }\end{array}$ & $1.80 \%$ & 150 & $0.82 \%$ & 620 & $1.64 \%$ \\
\hline Hungary & $1.76 \%$ & 180 & $0.98 \%$ & 433 & $1.14 \%$ \\
\hline Poland & $6.80 \%$ & 160 & $0.87 \%$ & 2579 & $6.82 \%$ \\
\hline Slovakia & $0.97 \%$ & 60 & $0.33 \%$ & 309 & $0.82 \%$ \\
\hline V4 & $11.33 \%$ & 550 & $2.99 \%$ & 3941 & $10.42 \%$ \\
\hline
\end{tabular}

Source: Personal calculations based on CIA World Factbook and ISAF mission website (valid as of 16 August 2011).

Given the figures from the examined data, although V4 countries' contribution in 2007 was considerably under the demanded level in comparison with their population's strength to the total European NATO members' population, by 2011 it had become almost equal. However, after examining individually V4 countries, only Poland meets the standard as a percentage of its population compared to the NATO's European population. The Czech Republic and Slovakia's troops' contribution nearly meets that standard, but Hungary's is still noticeably below expectations.

Hence another interesting, and to greater extent evaluative dimension to these calculations is a comparison of individual V4 states (the Czech Republic, Hungary, Poland and Slovakia) to the older NATO states of comparable population size (accordingly Belgium, Portugal, Spain and Denmark). When the examination of V4 countries' troop contribution is done from that perspective, troop contributions by the new members of NATO were consistently at or above the level of troops contributed by the older members with comparable size (except in the comparison of Slovakia to Denmark). 
Table 5: Comparison of Visegrad Group Members Countries' Troop Contributions to the ISAF Mission with Older NATO European States of Comparable Population Size

\begin{tabular}{|l|c|c|c|c|c|c|}
\hline \multicolumn{1}{|c|}{ Country } & Population & $\begin{array}{c}\text { Number } \\
\text { of soldiers } \\
\text { in armed } \\
\text { forces }\end{array}$ & $\begin{array}{c}\text { Recognized } \\
\text { as a troop } \\
\text { contribution } \\
\text { nation } \\
\text { 24 July 2003 }\end{array}$ & $\begin{array}{c}\text { Number of } \\
\text { Troops in } \\
\text { Afghanistan in } \\
2007\end{array}$ & $\begin{array}{c}\text { Number of } \\
\text { Troops in } \\
\text { Afghanistan } \\
\text { in } 2011\end{array}$ & growth \\
\hline $\begin{array}{l}\text { Czech } \\
\text { Republic }\end{array}$ & $10,190,213$ & 38,500 & 620 & $413 \%$ \\
\hline Belgium & $10,431,477$ & 39,000 & 24 July 2003 & 300 & 521 & $174 \%$ \\
\hline Hungary & $9,976,062$ & 30,000 & 24 July 2003 & 180 & 433 & $240 \%$ \\
\hline Portugal & $10,760,305$ & 42,700 & 24 July 2003 & 150 & 0 & $93 \%$ \\
\hline Poland & $38,441,588$ & 95,000 & 24 July 2003 & 160 & 2579 & $1612 \%$ \\
\hline Spain & $46,754,784$ & 126,000 & 24 July 2003 & 550 & 1523 & $277 \%$ \\
\hline Slovakia & $5,477,038$ & 17,000 & 24 July 2003 & 60 & 309 & $515 \%$ \\
\hline Denmark & $5,529,888$ & 29,950 & 24 July 2003 & 400 & 750 & $187 \%$ \\
\hline
\end{tabular}

Source: Personal calculations based on CIA World Factbook and ISAF mission website (valid as of 16 August 2011).

The Czech Republic, which comprises about 1.12 percent of NATO's population, had contributed 150 soldiers to Afghan stabilization mission in $2007 .{ }^{209}$ Four years later the Czech contribution grew about 413\% from the initial level, which resulted in 620 Czech troops deployed to Afghanistan. Belgium whose population is almost the same as the Czech, at the same time increased its detachment from 300 troops to 521 troops. ${ }^{210}$ In comparison to the Czech Republic, Hungary had deployed forces to a lesser extent (433 Hungarian troops), although its contribution still went beyond and became three times greater than that of Portugal in $2011 .{ }^{211}$ The conclusions from the examined data might differ

\footnotetext{
209 At the present time the Czech Republic's armed forces include 24,000 troops serving in line units, 3,000 troops in the service of auxiliary units, and 11,500 strong in men civilian personnel. In: Górka-Winter and Madej, NATO Member States, 28.

${ }^{210}$ Belgium has 39,000 strong professional armed forces capable of participating in expeditionary operations (about $60 \%$ of the total); Górka-Winter and Madej, NATO Member States, 12.

211 Today Hungary has about 30,000 soldiers (in 1989 they had more than three times larger armed forces). Portugal, like Slovakia, is considered a small NATO country with modest-size professional armed forces $(42,700)$
} 
in the juxtaposition of the Slovak troop contribution with the Danish. ${ }^{212}$ While the Slovak contribution also underwent a significant increase of troop deployment (about 515\% percent in comparison to 2007), it is still more less than half that of the Danish contribution.

However, what is most noteworthy is the Polish contribution to the mission in comparison to that of Spain. ${ }^{213}$ On average, Warsaw engaged less than 1 percent to NATO armed forces in years 2003-2006. The lack of engagement was mainly attributed to the commitment in Iraq, but Poland has gradually shifted its focus on the ISAF mission in Afghanistan. In September 2006, Poland at the request of the Supreme Allied Commander Europe (SAUCER) met increased ISAF requirements. Warsaw, like all of the other V4 countries, again responded to the request from NATO and significantly increased of its contributions to ISAF in forthcoming years, starting from 2007. Soon after the changes at the ministerial levels in Poland, the newly appointed Minister of Defence, Bogdan Klich, confirmed that Warsaw would remain engaged to the ISAF mission "with the view to Poland's credibility in NATO"214 Today, Poland deployes on Afghan ground about 2,579 troops, which means a 1612\% growth in comparison to 2007 . At the same time Spain noticed $277 \%$ growth in comparison to 2007 , even though on Afghan soil there are approximately 1000 fewer Spanish soldiers in comparison to the Polish deployment. ${ }^{215}$

- although, their armed forces are not considered to be very modern in accordance to NATO standards; GórkaWinter and Madej, NATO Member States, 56, 85-86.

${ }^{212}$ Slovakia is the smallest V4 member country with 17,000 strong modest armed forces. Denmark's partly professional armed forces contain about 29,550 military and civilian personnel. Presently, following military reforms, about $60 \%$ of Danish troops are able to perform duties in overseas deployments, and $10 \%$ of units are capable of being deployed immediately. Denmark also possess a territorial defense (the Home Guard) consisting mainly of reserve units, totaling 53,500 soldiers (they are part of "total defense" and integrated with civilian crisis management and public security structures); Górka-Winter and Madej, NATO Member States, 33, 94.

${ }^{213}$ In the XXI century Polish armed forces underwent a demanding process of professionalization. The last group of conscripted soldiers ended their duties in the Polish army in June 2009 and according to available data from September 2009 about 95,000 are of disposition of the Polish Army. "Professionalization Program for the Armed Forces of the Republic of Poland for the 2008-2010" was aimed at a number up to 120,000 professional soldiers. The professionalization process was also related to modernization of the army's equipment. In turn Spain is regarded as an important member of the Alliance given it crucial geo-strategic position in the western part of the Mediterranean. Spain has a fully professional 126,000-strong armed forces and is contributing considerably to the NATO budget, which has allowed Spain to be ranked seventh in the alliance; Górka-Winter and Madej. NATO Member States, 79, 102.

\footnotetext{
${ }^{214}$ Hillison, New NATO Members, 33.

${ }^{215} \mathrm{http}: / /$ www.isaf.nato.int/troop-numbers-and-contributions/index.php
} 
To sum up, by looking at the troop contributions in Afghanistan, the Czech Republic, Hungary, Poland and Slovakia have done quite well. When troop contribution lagged during the early phase of the ISAF mission, many scholars largely attributed it to the lack of capability versus the lack of willingness from particular countries to contribute to the mission. ${ }^{216}$ However, some of the critics pointed to the Czech Republic and Hungary, which had quite large armies, and emphasized that they contributed less than 500 troops each to ISAF mission purposes. Analyzing the above-mentioned data of total troops serving in the national armed forces of "new" and "old" NATO members of comparable size, we can see that although V4 countries have smaller armies they have deployed larger contingents to serve with ISAF mission (even as Turkey deploys about 30,000 troops in northern Cyprus and at the same time is contributing only 1,840 soldiers, to the most crucial NATO mission in its history). ${ }^{217}$

\subsubsection{Defense Expenditures}

Military expenditures are also linked by NATO and its members to estimate allied contributions to the Alliance. Therefore, another interesting dimension to calculation is a comparison of individual V4 states according to their defense budgets (in the academic literature on NATO the burden-sharing issue is measured by military expenditures as a percentage of GDP). ${ }^{218}$

Active participation in NATO missions like ISAF in Afghanistan also have demanded additional budgetary involvement from the V4 countries. This was particularly difficult for post-communist states during the transformation period of the 1990s. When V4 countries joined NATO they focused on the admission process to the EU, what they finally achieved in 2004. Thus, increased military expenditures had not been prioritized by the governments of Central European countries. Additionally, many of European leaders had been encouraging the V4 countries to attach importance to their policy of contributing to an European Union force rather than to the Alliance. ${ }^{219}$

\footnotetext{
${ }^{216}$ Hillison, New NATO Members, VII.

${ }^{217}$ Morelli and Belkin. NATO in Afghanistan, 22-23.

${ }^{218}$ Hillison, New NATO Members, 3.

219 Ibid.
} 
Nevertheless, once V4 member countries joined NATO and became obliged to participate in the peacekeeping mission within the Alliance, new budgetary demands came to light. The strategic concept adopted at the Prague Summit in 2002 confirmed a new criterion for NATO member states military spending as 2 percent of GDP, and required new members to meet this standard. ${ }^{220}$ Today, few NATO countries are meeting the alliance standard of military expenditures as a percentage of GDP. Data from 2009 revealed that only 4 of 29 NATO member countries (France, Greece, the United Kingdom and the United States) meets the standard of "2\%". Further, only about a dozen meet another adopted standard of $50 \%$ of their troops deployable and $10 \%$ sustainable. In this regard, the NATO benchmark of $20 \%$ of military spending dedicated for investment goals also has been executed by less than half of Alliance members. The military expenditure gap is remarkably visible in a comparison of European countries to the United States. American expenditures comprised $75 \%$ of total NATO spending in 2009. ${ }^{221}$

In a May 2008 Strategic Studies Institute Op-Ed, the lack of European determination to fulfill its pledges to NATO to a great extent referred to two aspects: "high European levels of social welfare and the pandering nature of their political systems". ${ }^{222}$ The demand for military expenditures is much more complex than it might look. Social welfare expenditures rival all remaining government spending, for example, defense on both sides of the Atlantic. However, Joel Hillison emphasize that it does not correspond to a deterministic interdependence between both social welfare and defense spending. By way of illustration, France, although has spends on public social welfare more than any other NATO member (28.7 \% of GDP), it also spent about 2.4 percent of its GDP on military expenditures in 2007. On the other side of the coin is Canada, whose level of public social spending is approximately 17.3 percent and military expenditures estimated at only 1.3 percent of GDP - in comparison the U.S. spends $16.2 \%$ on social welfare while on military expenditures 4 percent of its GDP. All these data might emphasize that there is something else than competing social expenditures in the equation. ${ }^{223}$ By the same token, according to Hillison, criticizing the lack of military expenditures on the parliamentary systems of the continent is hardly helpful or convincing. Bulgaria, Greece and Turkey - three European countries among six NATO members whose military spending

\footnotetext{
${ }^{220}$ Ibid., 3.

${ }^{221}$ Chappel, What Future for , 5.

${ }^{222}$ Hillison, New NATO Members, 4.

${ }^{223}$ Ibid., 5.
} 
exceeds 2 percent of GDP - have parliamentary systems. What is evident is that military expenditures in Europe have been in regular decline since the end of the bipolar system. ${ }^{224}$ The data provided in 2010 by the Center for Strategic and International Studies also proves that total defense spending in Europe was in decline in the first decade of the XXI century (see below).

\section{Total European Defense Spending and Defense Spending Per Soldier (2001-2008)}



Source: Hofbauer, Joachim and Roy Levy, Gregory Sanders, Matthew Zlatnik. European Defense Trends. Budgets, Regulatory Frameworks, and the Industrial Base (Washington: Center for Strategic and International Studies, Defense-Industrial Initiatives Group, May 2010), 3.

Moreover, the recent economic crisis strained V4 countries (except Poland which did not experience negative growth of economy, the only one to do so in Europe), and placed additional pressure on their defense budgets. ${ }^{225}$ In the case of V4 countries, military expenditures were also influenced by several other factors. To emphasize once again, for all of them it was simply unreachable or impractical to meet the standard of 2 percent of GDP, and even now they have not reached the demanded level of budgetary expenditures. ${ }^{226}$ Up to 2004 they were focused on accession to the EU

\footnotetext{
${ }^{224}$ Ibid., 6.

${ }^{225}$ Chappel, What Future for , 5.

${ }^{226}$ James W. Peterson and Terry Hallmark, "The New NATO Members and the Mission in Afghanistan: Political and Economic Risks" (New Orleans: Paper Prepared for delivery at the Annual Meeting of the Southern Political Science Association, 11 January 2008), 15.
} 
structures and with the NATO enlargement they felt that they also come under the American protective umbrella.

However, such recent circumstances as the Russian cyber-attack on Estonia in 2007, the bilateral agreement between Moscow and Berlin on building an under-sea gas pipeline, as well the 2008 Russian invasion of Georgia emphasized to Central European countries that they still can not forget about possible conventional military threats in this part of Europe. Not to mention that V4 countries have a deep rooted historic fear of abandonment by the West. Doubtlessly, historical legacy in the case of $\mathrm{V} 4$ countries plays a pivotal role. Czechs do not forget that their sovereignty was sacrificed to appeasement policies preceding the World War II. Poles until now remember how they were left alone to face the onslaught of Germany and the Soviet Union, regardless of existing military alliances with France and security assurances from the United Kingdom. Hungarians and Czechs also experienced brutal military interventions organized by the Kremlin in 1956 and 1968 respectively. ${ }^{227}$

A closer examination of the defense expenditures of V4 countries, even though they do not meet the NATO standard, reveals that Central European countries spend relatively more than their older allied countries. ${ }^{228}$ The budget of the Czech Ministry of Defense is estimated to about 56 billion CZK (about 3.11 billion USD), which comprise only $1.37 \%$ of country's GDP. ${ }^{229}$ Belgium spends on defense goals only $1.4 \%$ of its GDP in 2007, what was below the level of NATO's average defense spending estimated to be about $1.73 \%$ in 2007 (excluding the U.S. expenditures). These figures were decreased because of Belgium's budgetary difficulties in the hard times of financial crisis, reaching the level of less than $1 \%$ in 2010 as well as announced reduction to a 34,000-strong armed forces in $2012 .{ }^{230}$ Hungary's military expenditures in 2009 amounted to about 300 billion HUF (1.17\% of Hungarian GDP), but Hungary planned to reach the level of $1.3 \%$ GDP by $2013 .{ }^{231}$ Portugal also has limited budget possibilities, thus its defense spending amounts to $1.54 \%$ of GDP. ${ }^{232}$ Slovakia's military

\footnotetext{
${ }^{227}$ Hillison, New NATO Members, 14-15.

${ }^{228}$ Hillison, New NATO Members, VII.

${ }^{229}$ Górka-Winter and Madej. NATO Member States, 28.

230 Ibid., 12.

${ }^{231}$ Ibid., 56.

232 Ibid., 85-86.
} 
expenditures are also under the level of $2 \%$ of GDP. In relation to the global economic crisis the Slovak Ministry of Defense budget was reduced from 1.045 billion EUR to 822 million EUR, or only $1.22 \%$ of its GDP. ${ }^{233}$ Danish defense expenditures are amounted to be about 5.54 billion USD (1.7\% of GDP). ${ }^{234}$

The budget of the Polish Ministry of Defense in 2009 amounted to 24.86 billion PLN, estimated to be about 9 billion USD. The draft budget for 2010 proclaimed defense expenditures at the level of about 25.5 billion PLN (what meets the statutory level of 1,95\% of GDP from the previous year). Having in consideration that due to the financial crisis (and also remaining obligations from 2008 which had to be paid -2.5 billion PLN), this figure for defense expenditures express an increase in comparison with the critical year of $2009 .{ }^{235}$ In turn Spain is regarded as an important member of the Alliance given it crucial geo-strategic position in the western part of the Mediterranean. Spain has a fully professional 126,000 strong armed forces and is contributing to the NATO budget considerable means, which has allowed Spain to be rank seventh in the alliance (1.20\% of GDP). ${ }^{236}$

These results demonstrate that older NATO members have higher military spending as a percentage of GDP than V4 countries (except in the case of Poland in comparison to Spain). On the other hand, having in consideration troop deployment of individual countries in Afghanistan, this data shows also that V4 countries have allotted more money for the ISAF mission than NATO members with comparable size as a percentage of total military expenditures. According to the military expenditures of the greatest troop-contributing country of the V4 group, Poland, Polish Defense Minister Bogdan Klich declared that in 2010 final contracts within the Afghan package - a program of a special mode of purchases, carried out without offsetting conditions - the value of Afghanistan's total package was estimated about 1.4 billion złotych (over 400 million in 2009 and about a billion in

\footnotetext{
233 Ibid., 94.

234 Ibid., 33.

235 Ibid., 79.

${ }^{236}$ Ibid., 102.
} 
2010). The maintenance of the contingent cost nearly 315 million złotych in 2009 and 374 million złotych in $2010 .^{237}$

\subsubsection{The Costs of Humanitarian and Reconstruction Effort}

Stabilization of the situation inside Islamic Afghanistan requires not only the conduct of military actions but through the ISAF mission in Afghanistan, there is the development and reconstruction dimension where high expenditures are also demanded. Afghanistan is currently one of the largest consumers of international financial aid for rebuilding and reconstruction of the country. This aid is given by particular countries and also international institutions and organizations. ${ }^{238} \mathrm{~A}$ number of Central European countries' non-profit organizations also play a role in humanitarian and reconstructions efforts in Afghanistan.

These organizations are focusing on health, agriculture, education, health or security sector and public policy reforms. Since 2004 Afghanistan became an priority country in the Polish cooperation program for development. Only in 2006 within Polish development support was it planned to finance projects proposed by non-government organizations for a total sum of 1.6 millions Polish złotych. In 2007 the Polish foreign aid program implemented through the Ministry of Foreign Affairs allotted 8 million PLN for Afghanistan, to be spent through the section of civil-military cooperation (CIMIC) projects, with support of the Polish Embassy in Kabul and the Polish Military Contingent (PKW) in the operational area (as well as through the support of selected non-government organizations). ${ }^{239}$ In 2010 Poland allotted $22 \mathrm{mln}$ złotych for programs aimed at civil development for the Ghazni inhabitants. ${ }^{240}$ Poland has been actively involved in the process of creating democratic structures and reconstruction of post-war Afghanistan. In Afghanistan are present such Polish non-government organizations as Polska Akcja Humanitarna, Polska Misja Medyczna or Stowarzyszenie "Szkoły dla

237 PAP. Ile Kosztuje polaków Wojna w Afganistanie? Wirtualna Polska, 23.12.2010, http://konflikty.wp.pl/kat,1020347,title,lle-kosztuje-Polakow-wojna-w-

Afganistanie,wid,12976680, wiadomosc.html

${ }^{238}$ Winid, Udział Polski w działaniach stabilizacyjnych, 10.

${ }^{239}$ Katarzyna Hołdak and Anna Komarzewska. Afganistan, Irak, Czad - Co Mamy z Misji ? Bilans Zysków i Strat. Perspektywy (Warszawa: Biuro Bezpieczeństwa Narodowego, Bezpieczeństwo Narodowe, I-II,2008), 7-8.

${ }^{240}$ PAP, Ile Kosztuje polaków Wojna w Afganistanie? 
Pokoju". ${ }^{241}$ For instance, Slovakia continues supporting Afghan authorities through particular projects and programs within the area of the Official Development Assistance (ODA). Afghanistan was among 13 priorities for the Slovak ODA mid-term strategy for the years 2003-2008. Until 2008, several projects were approved for Afghanistan by the Slovak Trust Funding Steering Committee and consumed over one million USD and anticipates spending more in the future. Slovak aid was allotted on strengthening Afghan social and business development, particularly building schools in rural areas, education projects aimed at girls and women, fostering a culture of small enterprises led by women, local TV coverage, capacity building and democratization and civil society support as well. ${ }^{242}$

In turn Czech non-governmental organizations undertook activities at a school in the Afghan village of Itarchi. However, although Czech aid was not rejected, this support was a sensitive issue because only female members were permitted to work with Afghan females. The Czech Olivova Foundation supported projects aimed on improving children's health in Afghanistan. The Foundation focused their activities on combating the problem of the lack of drinkable water in many places, which resulted in greater risk of infection. They also devoted a much of their work to support Afghan orphanages. $^{243}$

As a reliable member of NATO, Hungary conducts international development cooperation in Afghanistan. Budapest guaranteed one million USD aid at the Tokyo donor conference in 2002, and in the next few years disbursed the entire amount of money. From 2004 to 2006, Hungarian police officers provided help to the German Police Project Team in Kabul, and the Hungarian Interchurch Aid NGO helped to construct several schools in Balkh and Samangan provinces. Budapest also allotted 200,000 USD to the Afghanistan Law and Order Trust Fund (LOTFA) in 2004. ${ }^{244}$ The establishment of the Hungarian PRT was accompanied by government aid for development projects in the amount of 500 million HUF per year. This sum ( 2 million EUR) was limited but on par with the previous development budget of the Dutch PRT $-5+1,6$ million EUR allocated in two years for projects only in Baghlan. The Hungarian Ministry of Foreign Affairs worked out this problem by seeking foreign investors who could aid their initiatives. Greece supported Hungary by offering 800,000 EUR for non-military programs in Baghlan. Another case is the Hungarian Interchurch Aid

\footnotetext{
${ }^{241}$ Winid, Udział Polski w działaniach stabilizacyjnych, 10.

${ }^{242}$ http://slovakia.usembassy.gov/op-ed.html ; http://www.centcom.mil/slovak-republic/

${ }^{243}$ Peterson and Hallmark, 19.

${ }^{244}$ Wagner, The Background of the Hungarian Activities in Baghlan.
} 
which with help from the Hungarian government applied to Japan's Grass-Roots Human Security Project (GAGGP) and finally obtained in total 975,000 USD. The European Commision also supported Hungary with 800,000 EUR. ${ }^{245}$

However, according to Peter Wagner here is a noticeable discrepancy between Hungary's recent military and development budgets. Budapest spent 32.4 million EUR in 2009 to maintain its military presence, while for development spending disposed on 1.65 million EUR. ${ }^{246}$ Following the Obama administration's declaration of December 2009 about increasing the number of American troops by 34,000 in Afghanistan, Hungary offered also 200 more soldiers, while for development tasks no extra money was allotted. ${ }^{247}$

The Hungarian Institute of International Affairs (HIIA) organized a conference at the end of 2009, where the most notable government officials and Afghan experts presented their opinion on Hungarian involvement in Afghanistan. Peter Wagner, an Hungarian analyst, summarized this conference in his paper as follows: "The global financial crisis hit Hungary hard. The government had to implement an austerity program which had an adverse effect on Hungarian development activities in Afghanistan. The PRT budget was cut back from 500 million to 459 million HUF. Moreover, due to the weak Hungarian economy, the national currency lost its value. In 2006 the 500 million HUF was worth 2 million EUR, but in 2009 this cut budget of 459 million HUF was equal to 1.63 million EUR. (The exchange rate was in 2006: 1 EUR = 250 HUF; in 2009: 1 EUR $\approx 280$ HUF)"248

In comparison to other nations, Visegrad group members' contribution are modest, but of course not without any meaning. Additionally it is worth mentioning that these non-profit organizations are not considered by the Taliban and insurgents as a friendly or neutral forces supporting Afghani civilians, but as occupying military forces and they target them as frequently as they do regular armed forces.

\footnotetext{
245 lbid.

${ }^{246}$ In 2008 for realization of the civil development projects Hungary established an annual budget estimated at 500 million Hungarian forints, what constitutes about 2,1 million euros;

http://www.mfa.gov.hu/kum/en/bal/foreign_policy/security_policy/hungary_in_nato/hungary_role_in_afghan istan/

${ }^{247}$ Wagner, The Background of the Hungarian Activities in Baghlan.

248 Peter Wagner also stated that considering the correlation between security and development efforts, the Hungarian PRT's budget was cut, while the insurgents networks were strongest ever since 2001. Ibid.
} 


\subsubsection{Effectiveness of Engagement in Stabilization Tasks and Combat Operations}

\subsubsection{Czech Republic}

During the visit of Deputy Defense Secretary William J. Lynn III to the Czech Republic, he discussed the ISAF operation in Afghanistan and the progress being made toward the transition of responsibility to Afghan authorities by the end of 2014. While meeting prominent Czech authorities, he thanked them for their armed forces' vital contribution in the NATO ISAF mission (as well as in Kosovo and Iraq). "The professionalism of Czech troops and civilian specialists in Afghanistan is highly valued by allied command and staff, including ISAF Commander Army Gen. David H. Petraeus", Lynn said. In addition Lynn applauded the so-called White Book on Defense, a plan for reforming and improving the Czech military and its defense procurement system, which should lead to increased possibilities for defense cooperation. He also mentioned that Americans had been able to assist the Czech forces with important support to their "training, communications modernization and air crew equipment", emphasizing that the cooperation on the Washington-Prague line was particularly efficient in the helicopter operations and training area. Regarding helicopter activities, he added that "Not only is the Czech Republic preparing Afghan pilots as part of our NATO mission (...) we also are working together on several current and future projects that will expand both U.S. and Czech capabilities to support a range of potential missions." Laid concluded his statements about AmericanCzech cooperation in terms of expanding their partnership. "Together" he said, "I am confident we can meet the critical security challenges of the 21 st century." 249

The Czech daily Mlada fronta Dnes wrote how Czech soldiers from the Special Operation Group (SOG) lost the trust of British troops after pulling out from several missions by reason of heavy combat engagement; another time they refused to join the operation, saying "that too many of them were on leave". According to the newspaper, encountering such an approach from Czech armed forces, British commanders were keen on co-operation with Danish troops. The Czech Republic's defense minister, Vlasta Parkanova, initiated a close scrutiny into the contingent's behavior, declaring that some of its members could be relegated. However, its commanding officer, Petr

249 John D. Banusewicz, Lynn Thanks Czech Republic for Afghan Help (Prague: U.S. Department of Defense, American Forces Press Service, June 15, 2011); http://www.defense.gov/news/newsarticle.aspx?id=64333 
Kcmar, asserted that such complaints are "nothing more than an excuse to dissolve the group, which operated under British command during a tour of Afghanistan that ended last year". 250

\subsubsection{Hungary}

When Hungarian troops were deployed to Baghlan Province in 2006, the security situation seemed to be stable. The Taliban presence was short-lived and only a few warlords posed a security threat in the Andarab Valley. Drug production was token and even decreasing since 2006, which led to the UN Office on Drugs and Crime declaration of Baghan as a poppy-free area in 2009. As it become the Taliban's target to expand the insurgency in the northern part of Afghanistan, Baghlan with its Pasthun minority also became the crucial object of intensive propaganda and anti-official actions. Anti -governmental actions especially increased after 2007. In the face of the growing insurgency movement, Budapest was operating under limited means to successfully combat anti-governmental forces. Owing the fact that the 240-strong PRT did not have a mandate to take active part in offensive combat actions, Budapest decided to enhance AFN capabilities through training and transfer of military hardware. A mutual Hungarian and American plan was proposed in 2008, when the Hungarian Minister of Defense and the US Ambassador to Hungary visited Baghlan province. Soon after, less than a year from that moment, ANA's base settled down in Baghlan province with the help of funds coming from Washington. In the beginning of 2009 ANA kandak (battalion) and HUN - US OMLT were deployed. ${ }^{251}$

These measures did not suppress the Taliban activities in province. Insurgents assumed control of the Baghlan Jadid, Dahan-e Ghori and Burqua districts. Central state power in fact have merely a theoretical presence in these areas. Moreover, police posts are constantly attacked and rebellions build provisional checkpoints and tax local inhabitants. Both insurgencies, in Kunduz and Baghlan provinces, are linked - the rebel forces in Kunduz take advantage of Baghlan Jadid for reinforcements

\footnotetext{
${ }^{250}$ Such accusations influenced negatively the reputation of the Czech contingent, and according to Mlada fronta Dnes, they also reflected deep-seated complications within the SOG and its ties with the Czech defense ministry. Several members expressed resentment of unclear rules for their deployment in Afghanistan, some threatened to give back decorations they were awarded for their duties in Afghanistan. The defense ministry also underwent criticism for its approach to the affair. Used on "close-protection" service, the SOG carries out responsibilities under the direct command of the Czech defense ministry as opposed to general staff; see Matthew Day, "Czech Troops' Abandoned British Soldiers' in Afghanistan", The Telegraph, (April 22, 2009); http://www.telegraph.co.uk/news/worldnews/europe/czechrepublic/5200990/Czech-troops-abandonedBritish-soldiers-in-Afghanistan.html

${ }^{251}$ Wagner.
} 
Here they are able to pull back after combat with the more offensively disposed German PRT and the AFS. The overall situation changed only with American reinforcements in the region. ${ }^{252}$

Hungarian Defense Forces plays a highly esteemed role in NATO missions, and their activities are well regarded by allies, which in point of fact demonstrates Hungary's leading role in several missions (in the SAF HUN PRT and at the Kabul International Airport). Moreover HDF member staff are frequently assigned to decisive positions at a growing number of NATO commands. In Gen. Kovacs opinion, "Unlike in the Balkans, consolidation is unfortunately out of the question in Afghanistan where the Hungarian Defense Forces' largest and most dangerous mission is being conducted, and we have to prepare for a gradually deteriorating security situation in 2011 too". 253

Budapest is criticized by NATO leaders predominantly for its lag in achieving force goals and integration, which can be affiliated to the three principal reasons: "over ambitious commitments before and after accession, continuous budget restrictions, internal political controversies and lack of social consensus". Nevertheless, according to Admiral James G. Stavridis, NATO's Supreme Allied Commander Europe, Hungary enjoys a good reputation as a strong and reliable ally of the NATO. ${ }^{254}$

\subsubsection{Poland}

In deploying its own forces to participate in the ISAF mission, Poland placed them at the disposal of the command of the operation without determining national restrictions. This allows for easier use of PWK in regions where the contingent will be necessary at any particular moment. It has particular importance in operation activities, because it allows for filling deficits in international forces in accordance to needs. A large number of countries participating in ISAF mission created national restrictions on their own forces, which hampers effective conduct of the mission. To a lesser extent, their also applies to countries who introduce for their own contingents national restrictions based on the lack of operational capabilities. Some activities undertaken in Afghanistan demand operating

\footnotetext{
${ }^{252}$ Ibid.

${ }^{253}$ Szabo, Increasing Role.

${ }^{254} \mathrm{http}: / /$ www.visegrad.info/european-security-transatlantic/factsheet/european-security-and-transatlanticrelations.html
} 
during the night or in difficult climate conditions. Not all countries posses the appropriate equipment which make them incapable to fulfilling mission goals in such difficult mountain conditions. ${ }^{255}$

The hardest criticism of Polish engagement in Afghanistan was contained in Time weekly magazine at the end of 2010. According to Time, when an American army battalion arrived to Ghazni province in summer 2009, they found Taliban who were resurgent in the area which they had pacified before they handed control to the Poles. An anonymous U.S. officer described how the Polish failure to patrol the critical roads between coalition bases lead to a situation whereby routes were "choked with roadside bombs". From what was described in the article, it appeared that Americans did not perceive Polish engagement as one that could lighten their armed forces' burden. Moreover, Americans claim that the Polish hierarchical approach to combat tasks is not appropriate when counter-insurgency campaign demands from mid and lower level officers to take real-time decision on the spot. They also criticize Poles for lack of continuity and that "logistics snafus make them dependent on U.S. support". ${ }^{256}$

Fortunately Americans and NATO quickly responded to the accusations coming from anonymous officers in the Time magazine. James G. Stavridis, NATO's Supreme Allied Commander Europe (SACEUR), stressed in a letter to the Polish Defense Minister that he absolutely does not agree with such an assessment of Polish troop activities in Afghanistan, emphasizing that Polish troops are well trained, experienced and devoted to the ISAF mission. ${ }^{257}$

General David Petraeus, commander of the ISAF and commander of the U.S. Forces Afghanistan (USFOR-A) from July 4, 2010 to July 18, 2011, in his letter also mentioned that he commanded international forces in Iraq and Afghanistan, and in both missions spent much time with Polish soldiers and evaluated highly the combat capabilities of Polish armed forces. He also announced that during his last visit in Ghazni he was "very impressed of the excellent work of the Polish contingent (...) and their excellent relations with Afghan partners". "In the past years, likewise in Iraq, Poland

\footnotetext{
${ }^{255}$ Winid, Udział Polski w Działaniach Stabilizacyjnych, 13.

256 Jason Motlagh, "For U.S. Troops in Afghanistan, Coalition Forces Are Mixed Blessinh", Time World (December 08, 2010), http://www.time.com/time/world/article/0,8599,2035859,00.html

257 PAP. 'Time' Krytykuje Polskich Żołnierzy - NATO ich chwali. Wirtualna Polska, 12.21.2010, http://konflikty.wp.pl/kat,1356,title,Time-krytykuje-polskich-zolnierzy-NATO-ichchwali, wid,12967721, wiadomosc.html
} 
had suffered heavy losses, but has never hesitated. "Therefore, all members of NATO in recent years acknowledged with applause that Polish authorities decided to increase its involvement in the mission", added Patraeus, and ended the letter concluding that "all Poles should be proud of the tremendous effort of Polish soldiers in Afghanistan". The U.S. General John F. Campbell, commander of coalition forces in eastern Afghanistan, also apologized to Klich for the anonymous comments of the U.S. military officers in Time. ${ }^{258}$

Stanisław Koziej, head of the National Security Bureau, described the publication in the American magazine as an attempt to find guilty for the bad situation in Afghanistan. According to the head of the NSB it was good that there were apologies to the Poles for this publication because it "reflects the official, formal stand of the U.S. authority and command". Koziej also added that such an article has to be treated seriously "as an attempt to frustrate American public opinion and attempt to review, find someone guilty, for why things go so badly (in Afghanistan), why clear vision has not been established". NBS' Chief also added that the article presents the basic dilemma which Poland has to face in Afghanistan - the dilemma of divergence of Polish contingent capabilities, operational capabilities and the scale and the nature of tasks needed to be performed there. ${ }^{259}$

Regardless of these facts, the Polish contingent is much more active than all other V4 member countries and many other old NATO members. The value of Polish soldiers was particularly appreciated Bogdan Klich, Polis Defense Minister in 2007-2011: "The high efficiency especially pleased, because now they have less incentive to be in the field, because after all in comparison to October the number of enemy attacks has decreased. The soldiers stay outside the base, carry out patrols, intercept dangerous cargo, eliminate opponents who are often the leaders of the Taliban". Klich also emphasized that since last year reconnaissance capabilities have dramatically improved. He mentioned that the first set of unmanned aerial reconnaissance aircraft, Scan Eagle, composed of five flying machines in the day and five at night (for the time being operated by Americans) were used in Spring 2010. The next set was launched in 2011. ${ }^{260}$

258 PAP. Dowódca ISAF: 'Polscy Żołnierze Imponujq Odwagq'. Wirtualna Polska. 20.12. 2010, http://konflikty.wp.pl/kat,1020347,title,Dowodca-ISAF-polscy-zolnierze-imponujaodwaga, wid,12963184, wiadomosc.html

${ }^{259}$ Ibid.

${ }^{260}$ PAP, lle Kosztuje polaków Wojna w Afganistanie? 


\subsubsection{Slovakia}

According to American Charge d'Affaires Eddins Lauds Slovak, the government has listed a democratic and functioning Afghan country as a top priority and Americans are impressed with Slovak contributions to the ISAF mission. He noted that Slovakia provides financial support, nongovernmental organizations run projects in different areas in Afghanistan and Slovak families are active in distance-adopting to help Afghan children, which together make the international community aware and admiring of Slovakia's effort to export its democratic experience to Afghanistan. Both NATO and the EU have recognized the threat of failing states such as Afghanistan as a threat to common security and, according to Lauds, "It is fitting that Slovakia - as a NATO ally is doing its part in ISAF, and actively seeking to do more". Lauds was also inspired the fact that common Slovaks are eager to help Afghans and share their difficult lesson of building democracy. The American Embassy in Slovakia cooperated with several Slovak organizations while they ran and implemented projects for Afghanistan. Among the most successful Slovak projects has been that in Peril since 2004, with the Afghan Women Resource Center, which has focused predominantly on "education for girls and women, income generation, civic rights, and community leadership". Since 2006 in Peril there has operated a "distance-adoption" scheme with the Afghan organization (Aschiana) and Slovak families have assisted in providing education for 55 children who had to work for their family's living on the Kabul streets. "On Your Side", a Slovak NGO affiliated with Handlova TV, carried out professional training for Kunduz regional television and the US Embassy in Slovakia provided support to journalists who gave "technical expertise and have also shown their Afghan colleagues how to do unbiased community reporting and maintain professional relationships with the local government." In general in the words of Lauds, the international community acknowledges Slovak activities in Afghanistan: the government effort, military presence and non-governmental projects. Slovak troops contributed significantly in Afghanistan, in KAIA service, clearing mines, providing medical services and as well repairing runways. Slovakia is assisting in the rebuilding of civil society in Afghanistan. Lauds concluded that the Slovak presence in Afghanistan demonstrates that Slovakia has influence far beyond its borders. "And Slovaks and Afghans alike are better for that". 261

\footnotetext{
${ }^{261} \mathrm{http} / / /$ slovakia.usembassy.gov/op-ed.html
} 


\subsection{The Evaluation of the Mission in Home Countries - Advantages and Disadvantages of Participation in the Mission}

\subsubsection{Public Opinion}

European authorities are guided and pressured by contrasting and paradoxical constituencies: the transatlantic - they acted in pursuance of solidarity and came after the US into Afghanistan after the 9/11 terrorist attacks; and the other side of the coin - local political opponents, who contemplate Afghanistan as dispensable and treacherous warfare. According to Fabrice Pothier these factors to a certain degree explain the "schizophrenic" Afghan course of European countries with parliamentary democracies, where government policy approaches frequently hijack foreign policy agendas. ${ }^{262}$ In addition we should add other factors such as different national interest of particular states, the visible "crisis" of European integration or the lack of a common European defense and security policy. One of the most crucial factors for the conduct of foreign policy by European NATO members is a public opinion support.

Europe's public support toward the United States and its foreign policy conduct has changed since the Bush administration left office. This shift to a more positive attitude toward the Obama administration was viewed as a test of how the ISAF mission in Afghanistan would be seen by worldwide opinion and whether the allies would continue to support it. Already examined data prove that Washington under Obama's presidency had won the support from the allied leaders in terms of providing additional troops for NATO's ISAF mission in Afghanistan. ${ }^{263}$ While European allies responded to American demands to do more, in the meantime they were under increasing pressure from European voters to do less. Poll after poll, starting from major European countries as France, Germany and Great Britain, and ending with Central European countries, find respondents declaring they want their troops withdrawn from Afghanistan and less of their money spent for that mission.

\footnotetext{
${ }^{262}$ Pothier, Europe: Loosing and at a Loss?

${ }^{263}$ Morelli and Belkin. NATO in Afghanistan,.11.
} 
According to Daniel Korski, the Afghan war, which initially was considered as a "forgotten war", later become recognized as Europe's unwanted war. ${ }^{264}$

There is not a shadow of doubt that in Europe public support for the Afghan mission has been lost. Leaders in European capitals are deprived of inestimable "political oxygen" desired to maintain a long and efficient engagement. A Pew Global Attitudes Survey shows that European voters straightforwardly claim that the mission in Afghanistan is a failure and are opposing further troop deployment. In fact it is highly visible that public opinion is a beneficial reality for European governments that seek a "free-ride". The Afghan stabilization mission is not a first concern for European citizens, but it is improbable that officials could be voted out of office over a remote war. The principal issues for voters have not changed as a result of Afghan war and they are still the same: unemployment, the economy and the cost of living. ${ }^{265}$ Moreover, unlike other NATO members, the mission in Afghanistan was not controversial during recent election campaigns in the Czech Republic, Hungary, Slovakia, and recently, in Polish parliamentary elections in 2011. ${ }^{266}$

\footnotetext{
${ }^{264}$ Daniel Korski, Shaping Europe's Afghan Surge (London: European Council on Foreign Relations, Policy Brief, March 2009), 2.

${ }^{265}$ Pothier, Europe: Loosing and at a Loss?

${ }^{266}$ Credible Deterrence for NATO in the XXI Century. Report from the Experts Roundtable (Warsaw: Arms Control Association, British American Security Information Council, Institute for Peace Research and Security Policy Hamburg, Polish Institute of International Affairs with Support of William and Flora Hewlett Foundation, 5-6 July 2010), 10.
} 
OBAMA APPROVAL LAGGING

IN CENTRAL AND EASTERN EUROPE

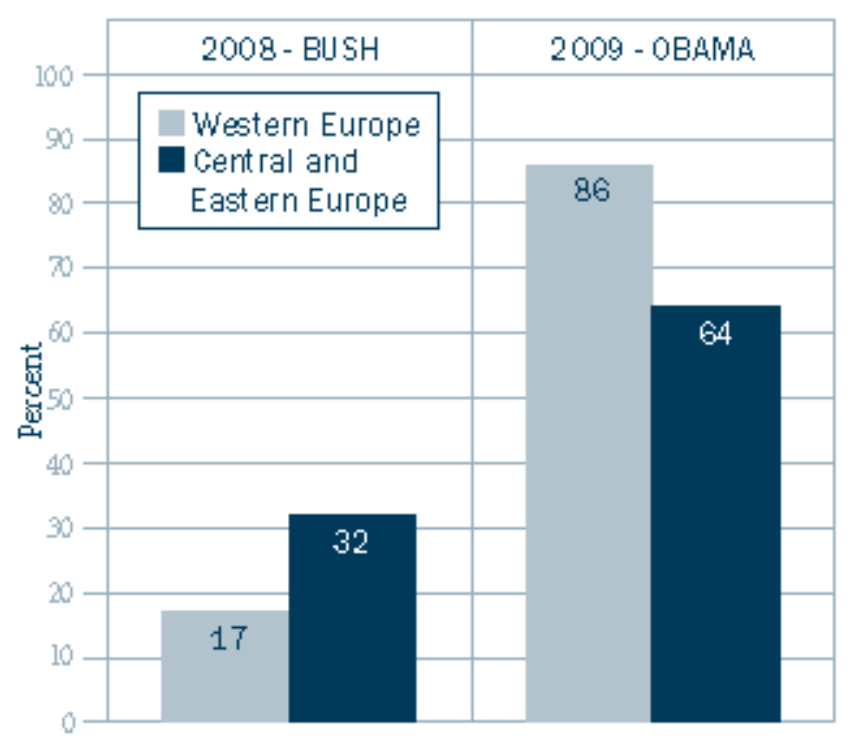

Source: Transatlantic Trends 2009: Kluczowe wyniki 2009, (German Marshall Fund of the United States, 2009), 10.

According to the Transatlantic Trends 2009 survey (public opinion poll conducted by the German Marshall Fund of The United States on 14 thousands citizens in 14 European countries and the United States), after the first six months in office, Barack Obama almost turned back the slump in public support for the United States, which occurred in most European countries under the presidency of his predecessor. In mid 2009 Obama enjoyed greater support in Germany, Great Britain, and even in France than at home. Nonethless, twenty years after the fall of the Berlin Wall, enthusiasm for Obama as political leader, American leadership or the United States in general, has become much more shaded in East-Central Europe than in Western Europe. East-Central European opinion polls much less perceived U.S. global leadership as a desirable thing. Support for NATO was weaker than in Western Europe and fewer people believed in Obama's capabilities to cope with global challenges. However, still more citizens of East-Central Europe than Western Europeans supported closer cooperation with Americans in the field of security, diplomacy and economy. ${ }^{267}$ To sum up the Transatlantic Trends in 2009, East-Central European citizens were less enamored with Obama than

${ }^{267}$ Transatlantic Trends 2009: Kluczowe wyniki 2009 (German Marshall Fund of the United States, 2009), 1. 
those in Western Europe. Therefore countries which were considered as the most pro-American in Europe have recently become the least positive toward the United States and its foreign policy.

Before examining the Transatlantic Trends of 2011, it is worth mentioning an interesting survey which was taken in Poland in relation to the Afghan stabilization mission issue. Poles critically evaluate the country's engagement to NATO operation in Afghanistan. According to the Public Opinion Research Centre (CBOS), in September 2009 three-quarters of the Polish population (76\%) opposed the participation of Polish soldiers in the mission, whereas only $20 \%$ were in favor. ${ }^{268}$ It is worth noting that in mid-2002, there more supporters of participation in the mission in Afghanistan than opponents. ${ }^{269}$ Polish public opinion not only does not support the participation of Polish soldiers in the mission in Afghanistan, but also disapproves such endeavors in essence. Moreover, Poles in comparison to another nationalities are characterized by critical attitudes regarding this issue. More than three-quarters of society (77\%) believe that the NATO mission in Afghanistan has to be stopped now, while only one of six believe that the mission should be maintained. ${ }^{270} \mathrm{~A}$ majority of Poles (71\%) doubted that the NATO forces' effort might help to establish peace in Afghanistan. About the possibilities of ending the fighting in Afghanistan through the NATO mission, only $17 \%$ of respondents believe in such scenario. ${ }^{271}$ Such large skepticism of Poles toward the NATO mission in Afghanistan translates directly into disapproval of the participation of Polish soldiers within the NATO operation. $^{272}$

However, in regard to this year's results of the Transatlantic Trends survey, Obama maintained high popularity in Europe. An impressive proportion (75\%) of surveyed populations of 12 EU member states approved Obama's policy to cope with global challenges. Although support was less to some extent than in 2009, it was still higher than for George Bush in 2008 (about seven times higher in France and Germany and four times greater in the UK and Turkey). In addition to East-Central

\footnotetext{
268 Światowa Opinia Publiczna o Polityce Stanów Zjednoczonych i Operacji NATO w Afganistanie. (Warszawa: Centrum Badania Opinii Społecznej, lipiec 2009), 1.

269 WBS. Polacy Przeciw Misji w Afganistanie. Warszawa: Gazeta Wyborcza.pl, 01.12.2010, http://wyborcza.pl/1,76842,8746447,Polacy_przeciw_misji_w_Afganistanie.html

${ }^{270}$ Światowa Opinia Publiczna o Polityce Stanów Zjednoczonych i Operacji NATO w Afganistanie, 2.

${ }^{271}$ Ibid., 3.

${ }^{272}$ Ibid.,4.
} 
European countries, Spain (68\%) showed relatively less support in comparison with the EU average, along with Slovakia (58\%), Bulgaria (63\%), Poland (65\%) and Romania(68\%). Over the last year support for Obama increased in Poland by (7\%), but decreased in another V4 group member, Slovakia, by 18 percentage points. Notwithstanding with the general approval of Obama's foreign policy approach to face the international challenges, the data showed that Europeans are less in favor of specific foreign policies. ${ }^{273}$

This year's research showed that Poland, considered as a leader of the Central-European countries, despite initial skepticism, shows stability in the terms of pro-Atlantic and pro-European orientation. In 2011, 74 percent of Poles declared a positive or very positive opinion about the United States (72 percent in the rest of the European Union). However it has to be mentioned that December 2010 visit of Polish President Bronisław Komorowski and later Obama's visit in Poland in May 2011, had a direct impact on such positive attitudes. Poles are keen on gestures and symbols, therefore they forgot about the issue of missile defense and anxiety associated to the reset of the U.S. policy toward Russia (this issue will be examined in a later part of this thesis chapter). Nevertheless, as it was already proved in the Public Opinion Research Centre (CBOS) survey from September 2009, Polish public opinion was very critical of the U.S. actions in Afghanistan. In 2011, 61 percent of Poles still evaluated it negatively. Obama's recent decision to withdraw 33,000 troops by September 2011, and to withdraw all troops together with other NATO member by the end of 2014, made critical assessments decline from 61 percent to 44 percent this year - to a level close to the average of the $\mathrm{EU}^{274}$

In addition to above information, the Transatlantic Trends 2011 surveys shows significant changes in European and American attitudes toward the Afghan stabilization mission. Until now we have observed a deep split between public opinion in the U.S. and the E.U in regard to the situation in Afghanistan and the future stabilization and reconstruction international efforts undertaken there. In 2009, up to 56 percent of Americans looked optimistically on the possibility to stabilize Afghanistan, while only 32 percent of Europeans expressed a similar opinion. This year's research shows that the optimism of Americans has fallen to 41 percent, which approached the level of European optimism.

\footnotetext{
273 Transatlantic Trends 2011: Raport 2011. (German Marshall Fund of the United States), 2011.

${ }^{274}$ Michał Baranowski, „Polacy Nie Chcą Wybierać Między Ameryką a Europą”, Rzeczpospolita (14.09.2011), http://www.rp.pl/artykul/9157,717188-Euroentuzjazm-i-sympatia-do-USA---German-Marshall-Fund-.html ; Mariusz Zawadzki, „Początek Końca Wojny”, Gazeta Wyborcza.pl (23.06.2011); http://wyborcza.pl/1,112353,9831394,Poczatek_konca_wojny.html
} 
According to Michał Baranowski, an expert in the Warsaw office of the German Marshall Fund of the United States, the lack of a common transatlantic vision for the future of the NATO mission in Afghanistan had previously threatened the future role of the NATO. This year the difference between American and European public does not exist. 66 percent of Europeans and as many Americans want to reduce or withdraw their troops from Afghanistan. According to Baranowski, this is good news for the future of NATO. ${ }^{275}$

\subsubsection{Casualties}

One of the key threats for armed forces are casualties during the Afghan stabilization mission. In regard to statistics compiled by 21 Søndag from 2009, Denmark is the country which lost the most ISAF soldier per capita of population (3.8 soldiers killed). The figures showed losses of other major contributing countries and Canada's losses were about 3.2, the United Kingdom's at 2.3 and American were 2.1 per million of population. ${ }^{276}$ The explanation of such large losses came from the Peter Dahl Thruelsen, researcher of the Danish Defense Academy: "We have not restricted the operational areas of our soldiers like, for example, France, Germany, Spain and Italy who have said that they are prepared to take part [(E.: in ISAF)], but not where it really hurts" and Danish soldiers carried out operations in very dangerous Helmand province.

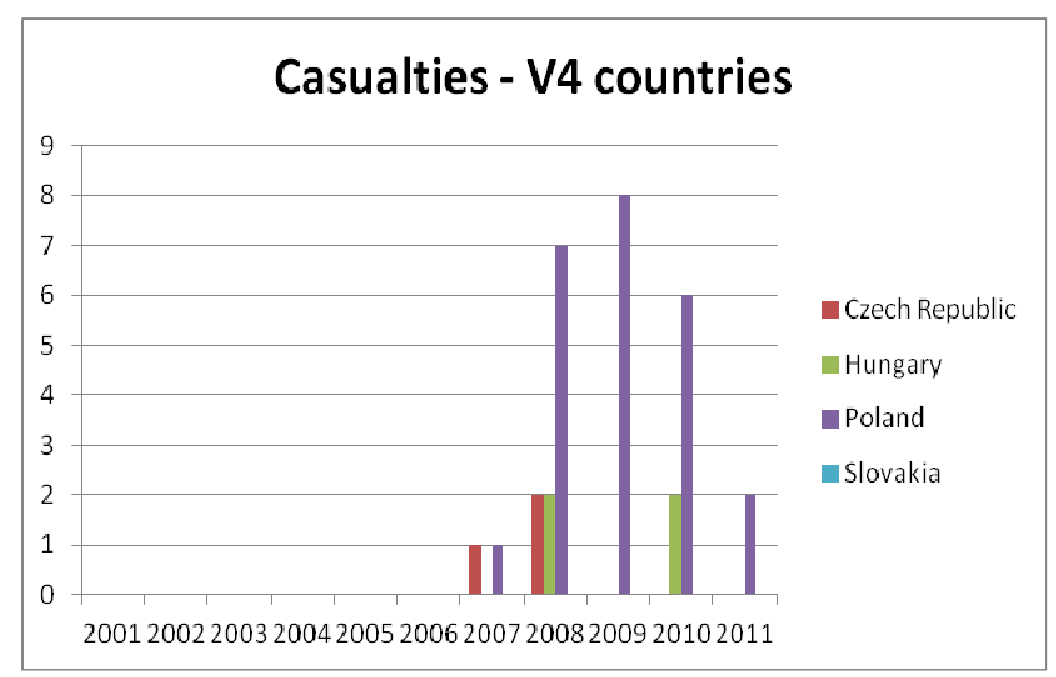

Source: Personal calculations based on: http://www.conflictmonitors.org/countries/afghanistan/facts-andfigures/casualties/security-forces. Valid as of 15 February 2011.

\footnotetext{
${ }^{275}$ Ibid.

276 Julian Isherwood, "Denmark Tops Afghan per Capita KIA Figures", Politiken (16 February 2009); http://politiken.dk/newsinenglish/ECE650209/denmark-tops-afghan-per-capita-kia-figures/
} 
As of as 15 February 2011, V4 casualties are low and such countries as Slovakia had not yet experienced casualties in Afghanistan. Other V4 countries casualties are not considerable in comparison to other coalition countries, however any losses have major political importance for countries participating in the ISAF mission. The Czechs are case in point of a new NATO member who particularly are concerned about threats to its military contingent. In April 2007, the Czech army had started operating in the mountains, in a remote area of Badakshan in the northeast part of the country. In the next month the vehicle which carried a Czech diplomat was fired upon. Although the diplomat was unhurt, his two bodyguards were wounded. A week later the growing threat was met with the first Czech military casualty. When heavy rains and flooding occurred in Fajzabad, landslides killed one Czech member of the local PRT, which found direct resonance at home. This "small" loss shocked not only the nation, but also the Czech military. While these accidents might be few in comparison to American losses, every casualty is accompanied by extensive media coverage which shows a hope to minimize all threats and keep away from any casualties at all. ${ }^{277}$ Such coverage is also visible in other Central European countries, and every loss negatively influences opinion polls, which demonstrate public desire to withdraw troops from Afghanistan. East-Central European countries public opinion is not accustomed to the fact that their soldiers are fighting somewhere in a distant country. Perhaps the East-Central European citizens are at the limits of their acceptance - as demonstrated in already examined data of public opinion polls on the mission in Afghanistan - after which they demand openly their own troops' withdrawal. It seems that although Central European countries' casualties, except for Poland, were really low in fact they were high enough to their citizens who indeed do not know what this war is about. Moreover, to add a new dimension to the problem, it is worth noting Polish car accidents, where in 2008 alone died 5,437 people. ${ }^{278}$ The death of every soldier or civilian in Afghanistan is a big tragedy, however I want only accentuate that if the opinion polls were more conscious about the aim of the ISAF mission - or less submissive to media coverage - we could be able to assess the acceptable number of casualties for a particular country. However right now it seems that no matter how many casualties occur, if 100 or 10 soldiers will die in Afghanistan, the citizens feelings will be the same and they will increase particular countries' motives to withdraw its troops from Afghanistan.

\footnotetext{
${ }^{277}$ Peterson and Hallmark, 6.

${ }^{278} \mathrm{http}: / /$ www.policja.pl/palm/pol/8/160/Wypadki_drogowe_w_latach_1985_2008.html
} 


\subsubsection{The Terrorist threat}

Before 9/11, somebody who would claim that Central European countries were at risk of terrorist attack might have been regarded as insane. The same thesis, stated right after the terrorist attacks on the United States, would be reasonably considered as unfounded and alarmist. However, ten years after the terrorist attacks such a statement would not be longer be something unusual. ${ }^{279}$ As a result of Central European countries' support for the United States policy and active participation in the ISAF mission (and Iraqi mission as well), V4 countries developed into a central target for those who oppose the mission in Afghanistan. In particular, given the central role of Washington as the key enemy for the terrorist forces, Central European countries become indistinguishably affiliated to the "war on terror", and also attached to broader American interest in the region. ${ }^{280}$ To paraphrase Bogdan Klich, however in a negative context, indeed flags of Central European countries become visible in Afghanistan for those who were targeted as an enemy of American and NATO - the forces of local and global jihad. ${ }^{281}$

However, in fact Central European countries has never been a primary preoccupation of Al-Qaida, although Europe experienced the occasional attention of terrorist organizations (train bombing in Madrid in March 2004, and transportation system in London in July 2005). In the statement "To the Peoples of Europe" former Al-Qaida leader, Osama bin Laden, singled out the continent and offered a peace proposal to European countries which would cease hostilities toward Muslims and stop their involvment in Muslim affairs. Bin Laden also presented in his statement the justification for undertaking terrorist acts and killing those who invaded or occupied Muslim countries: "Reality confirms we are right ... For we have only killed Russians after they invaded Afghanistan and Chechnya. We only killed Europeans after they invaded Afghanistan and Iraq, and we only killed Americans in New York after they supported the Jews in Palestine and Invaded the Arabian peninsula, and we only killed them in Somalia after they invaded it in Operation Restore Hope. We restored them to hopelessness, thank God". ${ }^{282}$ Presumably the increased level of engagement and activity carried

\footnotetext{
279 Ryszard Machnikowski, „Globalny Terroryzm a Sprawa Polska”, Stosunki Międzynarodowe (11 September 2011); http://www.stosunki.pl/?q=content/globalny-terroryzm-sprawa-polska

${ }^{280}$ Peterson and Hallmark, New NATO Members and the Mission in Afghanistan, 7.

${ }^{281}$ Machnikowski, Globalny Terroryzm a Sprawa Polska.

282 Bin Laden once again singled out European nations in the audio statement on Al Jazeera television on November 29, 2007. He mentioned the NATO forces contributing to the ISAF and advised European capitals to stop supporting Americans and cease their commitment to the mission; Peterson and Hallmark, 7-8.
} 
out by V4 countries within the ISAF operation might escalate an animosity and hatred by jihadist networks, especially as those nations carry out more frontline or battle responsibilities. ${ }^{283}$

The various events which have occurred since 9/11 made the terrorist threat from jihadists more possible to occur because of several factors. It is estimated that Al-Qaida operates in at least 15 European countries, and the terrorist attacks in Spain and England proved the existence of fringe groups associated with Al-Qaeda and that individual Islamists are capable to carry out attacks in European capitals. Moreover, terrorist experts emphasizes that the Al-Qaeda network has splintered and morphed into a different kind of organization and the terror methods and tactics constantly change, aiming at new and different targets. ${ }^{284}$ The V4 countries accession to the EU and the further implementation of the Schengen treaty meant that Central Europe has opened itself to the free movement of capital, goods and people from the Western European countries, and especially those where terrorist networks are well based in the underground (Germany, France, Great Britain and the Netherlands - countries where Central European nations are keen to emigrate and might come into contact with terrorist networks). Moreover, citizens of those countries found an opportunity to penetrate Central European countries, and now it has become more complicated to control these who might potentially pose a risk or undertake suspicious activity in the Central European countries. $^{285}$

Therefore, Visegrad member countries might become a new targets of terrorist organizations if their presence on Afghan soil remains active and countries already hit by terrorists (Spain, England) undertake counterterrorism measures, which simply makes V4 countries easier targets for terrorists. The question is, given the psychology of terrorists, is there any distinction being made by those who are able to terrorize NATO members, between both the "old" and "new" Europe and between NATO members ? Even owing to the fact, that V4 countries would constitute softer targets for terrorist organizations with Al-Qaeda at the head, why would they attack in Central Europe if more intriguing targets are still associated with Western European countries - the "old" Europe. But this might change when such countries like Poland and Ukraine will be organizing European Championships in $2012 .^{286}$

\footnotetext{
${ }^{283}$ Ibid., 9-10.

${ }^{284}$ Ibid., 9-10.

${ }^{285}$ Machnikowski, Globalny Terroryzm a Sprawa Polska.

${ }^{286}$ Peterson and Hallmark. The New NATO Members and the Mission in Afghanistan, 9-10.
} 
Such events as the co-organization of the European Championships in football by Poland can significantly raise the level of risk, simply because international mass sport events are particularly good targets for terrorist actions. It should be noted that especially in the case of Poland the consciousness of terrorist threat for those who are responsible for national security has changed significantly over the past years. ${ }^{287}$ Moreover, again in case of Poland, the close cooperation by Poles with the U.S. intelligence and as a result the discovery of the so-called "secret prisons" of the CIA on Polish territory results in higher risk of terrorist threat. In these prisons were held the most important commanders of Al Qaeda, captured around the world, including Khalid Sheikh Mohammed, the alleged "architect" of September 11, 2001 terrorist attacks. Straying from the fact whether it was true or not, the media coverage on a global scale made Poland directly assigned to the place where Al Qaeda prisoners were tortured by CIA officers and it is hard to imagine an effective campaign to vanish such linkages to Poland. Thus, once again, we can assume that for weakened jihadist planners Poland and other Central European countries can be easier targets than Western European countries. $^{288}$

To sum up, the arising terrorist threat for $\mathrm{V} 4$ countries is a direct consequence of conscious decisions taken by the governments of particular countries aimed at increasing the importance of V4 countries on the world stage and realization of their "raison d'etat". The threat of the global terrorism has increased significantly owing the fact that V4 countries are holding the mass sport events, but also they have run the EU presidency and have hosted a number of EU events on their territories. It would be even more than naïve to deny that the outcome of the mission will bring a possible terrorist threat on home ground. ${ }^{289}$

\footnotetext{
${ }^{287}$ Machnikowski, Globalny Terroryzm a Sprawa Polska.

${ }^{288}$ Ibid.

${ }^{289}$ Ibid.
} 


\subsection{The New Shape of the American - Central European "Special Relationship"}

Due to their engagement in the military operations and contribution to NATO's military and defense capabilities development, Poland and other V4 countries have constructed the image of responsible members of the international community. Nevertheless, it is assumed that investment of troops and money did not translate into change of relations with the USA in particularly sensitive areas, as expected by Central European governments. ${ }^{290}$

As noted in the beginning of the previous chapter, as former Soviet vassals, Central European states demonstrate two fundamental needs - security and economic development. Starting with the security issue, they sought for a protection against historic enemies in the region, almost entirely Russia, owing the fact that Germany is no longer considered as a possible conventional aggressor. Central European politicians are aware that the only country who might provide such security is the United States. On the other hand, seen from the economic development perspective, the EU on the whole is natural source of subsidizes; still the relationship between "East" - "West" Europe is not ordinary. As believed by Michael Radu, even if the military contribution of nations from both sides of Europe pale significance compared to any activities Washington may carry out, the economic correspondence is more tangled. In fact Central Europeans need EU investment and aid, but recent years after their accession show that the EU also need East European markets and labor. On that account security correlation is far more asymmetric than the economic bonds. ${ }^{291}$ Not to mention unquantifiable belief, so ubiquitous in Central Europe, that throughout the hard years of communist misery it was the United States who, at least rhetorically, were firmly on the anti-communist side. Central Europeans were prodigiously thankful for the indomitable anti-communism embodied in President Ronald Regan, and saw the United States as the foremost guarantor of their independence from the Soviet Union's successor, Russia, after the collapse of communit system in 1989.

\footnotetext{
${ }^{290}$ http://www.visegrad.info/european-security-transatlantic/factsheet/european-security-and-transatlanticrelations.html

291 Michael Radu, Old Europe vs. New, Philadelphia: Foreign Policy Research Institute, E-notes (March 12, 2003); http://www.fpri.org/enotes/20030312.radu.oldeuropevsnew.html
} 
Furthermore, it was Washington's pressure that saw Central-Eastern European countries accessed to NATO in 1999. ${ }^{292}$

When in 2003 Bush's administration undertook a political drive for worldwide support to launch military action against Saddam Husain's dictatorial rule, eight countries (five EU members - Denmark, Italy, Portugal, Spain and the UK, and three new NATO members - Czech Republic, Hungary and Poland) signed a declaration in Madrid reassuring the United States' of their support on Iraq. ${ }^{293}$ The nature of the Central European countries commitment was unambiguous, especially owing the fact that they challenged the shaded threats and disdain of French President Jacques Chirac and publicly supported Washington's policy. ${ }^{294}$ Being aware of fact occurred at a time when Central-Eastern European countries still were not a members of the EU, showed region's independence and growing confidence of their political establishments. ${ }^{295}$

The Bush administration had valued Central-Eastern European countries for their military commitment to the Iraqi and, later on, in the Afghan mission. Likewise their special cooperation on missile defense project and the region's advocacy for the NATO and EU integration of Georgia and Ukraine were applauded. The missile defense project was an issue of crucial importance in that it made the Czech Republic and Poland major partners in countering ballistic missile proliferation, and would also have framed a special bilateral security relationship with Washington. However, Bush's administration made a mistake by identifying East-Central European countries as a "New Europe" and distinguishing them from the "Old Europe", with which the United States had been allied since the beginning of the Cold War. The political division of the Old Continent became again highly visible

\footnotetext{
${ }^{292}$ There is an opinion among scholars that Warsaw had reciprocated by buying 48 F-16 fighters from U.S. through Lockheed Martin Corporation, regardless of a challenging bid from producers in Europe. But if we consider that only real threat for Poland comes from Russia, F-16 fighters are the best military tool to repulse an enemy attack from the East, because they were constructed by Americans in the aim fighting the Soviets. Thus, the decision to buy American fighters was pragmatic rather than ideological.

${ }^{293}$ The following month in Vilnius another ten East-European countries that years would soon be NATO and EU members (Albania, Bulgaria, Croatia, Estonia, Latvia, Lithuania, Macedonia, Romania, Slovakia and Slovenia) also supported the United States.

294 "Parade of vassals" - smoldered a German member of the European Parliament. In a turn for the worse, French President Chirac simply asked the Central European leaders to "shut up" and to discontinue being "infantile" - what did not disturb the leader of the country whose language seems to be equivalent with diplomacy to threaten their accession to the European Union; see Michael Radu, Old Europe vs. New.

295 Jeff Lightfoot, America's New Partnership with Central Europe, Washington D.C.: Atlantic Council (November 6, 2009); http://www.acus.org/new_atlanticist/americas-new-partnership-central-europe
} 
and strained the region's relationship with its Western neighbors on the eve of the European Union's first big enlargement to the East. By focusing a centre of activity in Central-Eastern Europe for its political agendas against strong opposition from allied capitals as Berlin and Paris, Bush's administration simply affronted major "Old European" nations. Moreover, by granting a special relationship to a Central European leader, Poland, on NATO enlargement and missile defense, Washington again directly argued Moscow. ${ }^{296}$

When the new American administration declared it will be on the lookout for a "reset" in relations with Russia, the countries of Central and Eastern Europe became wary of the new US leader's overtures to their greatest historical enemy from the East. They wondered whether the new American policy approach to Russia would also impact their relationship with Washington and downgrade them in favor of better cooperation with Kremlin. ${ }^{297}$

\subsubsection{The United States Shifting Agendas}

The Obama administration had to shoulder responsibility for conduct of foreign policy when tough global challenges and problems exceeded the ability of the contemporary hegemonic country to handle them on its own. The new establishment in Washington understood from the beginning that Obama would need all the help he could obtain on difficult issues like Afghanistan, Iran's effort to possess weapons of mass destruction, or to put a stop to global warming. To put it another way, Obama needed a strong and united Europe as a partners and had to get the Kremlin to not play the role of "spoiler". These objectives largely shaped the intellectual approach of Obama's program toward the continent and Russia. ${ }^{298}$

When the new policy approach was put into practice several shortcomings appeared. The most important was the implementation of Obama's administration policy immediately pairing, supposed to be separated, polices, one toward Russia, the offer to map out a "reassurance" approach towards Central-Eastern European countries. According to Jeff Lightfoot a sequence of poor diplomatic work by the Obama administration to a great degree insulted the countries of the region, even preceding the bungled rollout of the new missile defense program. Nonetheless, in his opinion Washington might be forgiven for creating sour feelings in the Central-Eastern region. Especially when "Poland's paranoia" made its occasionally not the easiest ally and the Czech Republic's poor performance of its

\footnotetext{
296 Ibid.

297 Ibid.

298 Ibid
} 
Presidency of EU complicated faith in the region's leadership. Moreover, at that time, President Vaclav Klaus's delaying tactics on the Lisbon Treaty appeared symptomatic when Washington sought to employ the continent as a more effective global partner and closest ally. ${ }^{299}$

\subsubsection{The American September Affronts and the Missile Defense Case}

As September 11 has historical meaning for the U.S., for Central Europeans citizens the first of September symbolizes the start of World War II. Since the $70^{\text {th }}$ anniversary of this event, to some scholars this day marks also the end of period of special relationship between Warsaw and Washington. The heads of the state from Europe jostled for space at the place where the opening shots of WWII were fired. Near the Gdansk memorial were gathered such notable politicians as German chancellor Angela Merkel and Russian Prime minister Vladimir Putin. Among them stood Gen. James Jones, the US national security adviser. For Poles, to whom this event had a huge symbolic meaning, the inadequate priority given by Obama's administration by designating national security adviser was a sign of United States' shifting agendas. The new American administration was focused on the aftereffects of the global financial crisis, terminating war in Iraq and giving higher priority to the one in Afghanistan, in the meantime keep under observation China, North Korea and Iran - not to mention Obama's effort to reform American health care system. ${ }^{300}$ On the authority of Daniel Rotfeld, a former Polish foreign minister, "the US has acknowledged that the transformation of Europe was a success and that there is no need to be occupied with this region". Under Obama's presidency the shift in views become apparent, that the US was no longer concerned about regions like Central Europe, which do not require immediate attention, which than revealed a noticeable cooling in pro-American opinion in conducted surveys in Central Europe. Poles supported George W. Bush's foreign policy approach more than the majority of other remaining countries in the world, including the United States. While Western Europeans shuddered at Bush's conduct of foreign policy, they became highly supportive for Obama's approach. In contrast Central Europeans displayed a reverse attitude (as was already mentioned the Transatlantic Trends poll indicated in 2009, only 55 percent of Poles supported Obama, the lowest level in Europe - for instance at the same time 88 percent of the French favored Obama). ${ }^{301}$

\footnotetext{
299 Ibid.

300 Jan Cienski, “The Decline of America and Poland's Special Relationship", Global Post (September 10, 2009); http://www.globalpost.com/dispatch/poland/090909/poland-usa-foreign-policy ${ }^{301}$ Ibid.
} 
Perhaps the decision over who was to be sent to Gdansk commemoration could be acknowledged as solely symbolic, if it were not connected to more substantial decisions demonstrating the US disengagement from Central Europe. The most controversial issue of the US - Central European Russian triangle of relations at the end of the first decade of XXI century, was the American plan to locate the missile interceptors in Poland with linked radar in the Czech Republic. The Bush administration defended the necessity of the shield by the existence of so called "rogue states", for example Iran, in the general neighborhood of the continent. The Czech Republic and Poland, chosen for the sites together with other countries of the "new" Europe, gave decisive support to United States policy in the early days of the Iraq war. Nevertheless, Czech and Polish publics feared that the building of anti-missile infrastructure on their territory together with involvement in Afghanistan and Iraq would only anger more terrorists and simply invite terrorists attacks. ${ }^{302}$

During the presidency of George W. Bush, the Poles were tough negotiators trying to locate the stationing of a battery of Patriot missiles in return for allowing the location of an American missile interceptor base on Polish territory. The idea of missile interceptors' emplacement together with a battery of Patriots in Central Europe naturally brought Russia into the cauldron which perceived this program as a potential threat, and provoked anxiety among Czech Republic and Poland's European Union allies. ${ }^{303}$ President Putin several times suggested that they could use different location, offering for example an existing Russian radar station in Azerbaijan, or he simply threatened to build own facility and even reminded Prague and Warsaw that Russia will threaten them by aiming their ballistic missiles on them. Discussions in the Czech Republic and Poland in part concentrated on the manner of approving or disapproving the installation of American military infrastructure. One of the possibilities was to undertake a national referendum in both countries, which could have lead to a populist campaign against it. The other way of solving the issue was a submission to both chambers of the Polish and Czech legislature for ratification. ${ }^{304}$

Whether the Russian threat had anything to do with Polish and Czech involvement in the ISAF mission in Afghanistan is hard to prove, but indeed it reveals another dimension of the uncertainty in Czech and Polish closeness to Washington policy. Concessions to Moscow made by Americans did not satisfy Russia, even as Americans indicated that only an attack by Teheran would launch the

\footnotetext{
${ }^{302}$ Peterson and Hallmark, 13.

${ }^{303}$ Cienski.

${ }^{304}$ Peterson and Hallmark, 13-14.
} 
missile system in Central Europe. More controversial were American proposals to allow Russian personnel to access the military infrastructure on Czech and Polish soil, to end their doubts about the aim of the system. That proposal alienated both V4 countries who still remember the Soviet occupation of their countries. ${ }^{305}$

The initial drift by Obama's administration in its policy had worried Central European leaders who decided to send a letter to Washington emphasizing that the missile defense program would be considered as a litmus test of the significance the United States places on its relationship with Central Europe. ${ }^{306}$ Into the bargain the letter made Washington aware that it needed to make much more effort if it wanted to keep close ties with Central Europe, by reason of the fact that a new generation of leaders coming to power was far from being strongly pro-American. ${ }^{307}$ Indeed, when the new American administration abandoned missile defense plan on September 17 in the name of better Russian-American partnership, Central European governments regarded that as a devaluation of strategic role of this region. It is worth noting that this low point of the American - Polish relationship occurred at a day which has extraordinary meaning for Poles - it was a $70^{\text {th }}$ anniversary of Soviet invasion of Poland during the Second World War and was interpreted either as extreme clumsiness, or an affront from the Yankees. ${ }^{308}$ Under Polish prime minister Donald Tusk and the new generation of Central European leaders, in particular in V4 countries, this gave new impetus to V4 countries to reconsider their foreign policy toward Berlin and Moscow. ${ }^{309}$

\subsubsection{Central European "Reset Button"}

President Barack Obama's advisors noticed that they committed a number of missteps toward Warsaw and other East-Central European capitals. Therefore Obama decided to pay a visit to Warsaw in May 2011 and tried to wipe out his administration's mistakes toward faithful allies in this

\footnotetext{
305 Ibid., 14.

${ }^{306}$ GW. An Open Letter to the Obama Administration from Central and Eastern Europe. Gazetawyborcza.pl, 15.07.2009, http://wyborcza.pl/1,76842,6825987,An_Open_Letter_to_the_Obama_Administration_from_Central.html

${ }^{307}$ Cienski, The Decline of America and Poland's Special Relationship

${ }^{308}$ Heather A Conley, President Obama's Return to Prague: An Opportunity to Reset. Center for Strategic and International Studies, April 5, 2010, http://csis.org/publication/president-obama's-return-prague-opportunityreset

${ }^{309}$ Kiss, Central Europe, 94.
} 
particular region of the world. As usual in such visits there were many compliments in regard to Poland as a European state which avoided the recent economy crisis, as a leading country of this part of Europe, and also a perfect model of successful transition to democracy for the Arab countries. Obama knew that dealing with the very sensitive Poles, most important are gestures and symbols. Hence, during his nearly 23-hour visit, he laid wreaths three times and met with representatives of Polish democracy which was aimed to build a positive image of the visit and to satisfy the Polish political class. Although the visit had clearly symbolic meaning, indeed it created Polish pride against the background of the East-Central European region. Although these complements were authentic, they were also directly addressed to fulfill simple Polish emotional needs to be appreciated by other states and especially the "modern Rome", which undoubtedly is reflected in today's Washington. ${ }^{310}$

However, it seems that Central European countries have resigned from the minimalistic approach to diplomacy - where success was considered by bringing to the table worldwide leaders of strategic importance. Indeed, entering into the second decade of the XXI century, Poland and Central European countries started assessing the meetings through the prism of particular agreements and their final positive outcomes for the national interest. ${ }^{311}$ Instead of the role of "advance base" of Washington's foreign policy, Warsaw in the XXI century has found two different solutions to its position on the geopolitical scene - try to go through reconciliation process with Moscow on the ground of pragmatic mutual interests and increasing closer cooperation with Germany. Czech governments also had to chose between an acceptable position between Berlin and Moscow, or make an effort to cope with the political demands of being Washington's "bridge-head" in Central Europe. The highly motivated engagement of Warsaw and Prague in the American missile defense plans reflected the divergence in security perceptions between the "southern" and "northern" wing of the V4 countries. The Czech Republic and Poland tended to strengthen the Trans-Atlantic agenda in Europe against the German-Russian cooperation and additionally to gain strength in negotiations with the EU. Hungary, shifted toward a positive attitude toward Germany and a "cross-party Atlantic

\footnotetext{
${ }^{310}$ However, there can be found a one real positive effect of a meeting between American President and Polish prime minister Donald Tusk in regard to shale gas on Polish territory. Perhaps it motivated Polish authorities to make it easier for Americans to invest in Polish shale gas and realize budget benefits from gas drilling if appropriate tax revenues could be ensured. See Zbigniew Pisarski, „Polska Jest Cheerleaderem w Oczach Ameryki - Czas na Real Politik", Stosunki Międzynarodowe (05.06.2011); http://www.stosunkimiedzynarodowe.info/artykul,1018,Polska_jest_cheerleaderem_w_oczach_Ameryki_?_cz as_na_realpolitik

${ }^{311}$ Pisarski, Polska Jest Cheerleaderem w Oczach Ameryki.
} 
commitment", whereas Hungarian political parties represent different attitudes toward policy against Russia, which has not refused the interest-driven cooperation. ${ }^{312}$

Analyzing precisely the Polish case, this country has undergone in recent years the most vivid change - from a tiresome country tending to undertake tactless behavior to confront major EU countries, such as Germany, to a pragmatic team player who is ready to adopt leadership responsibilities within EU and NATO. ${ }^{313}$ During the Kaczyński brothers' era, 2005-2007, Poland was particularly confrontational in the EU and the Atlantic cooperation was a core of Polish foreign policy. ${ }^{314}$ The attitude to foreign policy changed when pro-business and centrist party, Civic Platform, won parliamentary elections in 2007. ${ }^{315}$ Jarosław Kaczynski's successor, Prime Minister Donald Tusk, also shared theses values but in addition decided on a more open and pragmatic policy approach toward the major European countries (Lech Kaczynski served as president until April 2010, when he died in a dramatic plane crash). One of the key changes implemented by Tusk's government was to improve relations with the crucial EU members, Germany and France, as well as major non-member countries pivotal for economic interests such as Russia. If truth be told, animosities against Germany and Russia are still strong in Poland; nonetheless Tusk has made efforts to go beyond those animosities, often abandoning the anti-German rhetoric from the Kaczynski times and has developed a great relationship with German Chancellor, Angela Merkel. ${ }^{316}$

The new generation of Polish politicians would rather based the country's relations with Russia on a mutual interest agenda with great potential than on a confrontational approach which does not give any economic benefits. Germany is the most important supporter of Poland, and to a lesser extent, other Visegrad group countries. When Guido Wasterwelle was appointed as the new foreign minister in Germany, he decided, before visiting Paris, to pay his first official visit abroad to Warsaw, which

\footnotetext{
${ }^{312}$ Kiss, Central Europe, 93.

${ }^{313}$ Rikard Jozwiak, "EU's Largest New Member, Poland, Takes Over Presidency", Brussels/Warsaw: Radio Free Europe (June 30, 2011); http://www.rferl.org/content/eu_largest_new_member_poland_takes_over_presidency/24251314.html

${ }^{314}$ Led by twins Lech and Jarosław, deeply conservative and traditionalist Law and Justice party (PiS), controlled both the presidency and the government.

${ }^{315}$ Civic Platfrom won again Polish parliamentary elections in 2011, and for the first time in the Polish modern history Donald Tusk will serve a second term in the office.

${ }^{316}$ Jozwiak, EU's Largest New Member, Poland, Takes Over Presidency.
} 
symbolized the special strategic importance of Poland to Germany. ${ }^{317}$ Poland understood that it is better to have Germany on its side than pointlessly oppose the largest EU member. According to Bartek Nowak, executive director of the Centre for International Relations in Warsaw, "we (Poland) understood and implemented in practice the old adage, that you can achieve a lot with Germans, but nothing opposing them (...) therefore we implemented it - basically, in every policy we try to consult with Germans and have them on our side". ${ }^{318}$

Donald Tusk's foreign policy approach also demonstrated that the pragmatic policy toward Russia is even possible from Poland, a country considered as the most anti-Russian state among the V4 countries and within the EU as well. ${ }^{319}$ When Russian Prime Minister Vladimir Putin together with Tusk paid tribute to the Polish military officers murdered by Soviets in the Katyń forest in April 2010, it was acknowledged as the first considerable step into the normalization of the Polish-Russian relationship. Unfortunately, a few days later one of the biggest Polish national tragedies occurred, when Lech Kaczynski died in a plane crash in Russia on his way to another ceremony to honor victims of Katyń. ${ }^{320}$ Real and heartfelt sympathy from the Russians contributed to a further warming of Polish-Russian relations, although this thaw also had some critics. ${ }^{321}$ Regardless, in terms of relations

${ }^{317}$ Kiss, Central Europe, 95-96.

${ }^{318}$ Jozwiak, EU's Largest New Member, Poland, Takes Over Presidency.

${ }^{319} \mathrm{Ibid}$

${ }^{320}$ It is noteworthy that history policy was a core of the Law and Justice government and the Katyń issue was significant to their policy toward Russia. However the pragmatic approach of Donald Tusk has had positive effects, and was "awarded" by the Russians, which additionally supported the effectiveness of that particular approach toward Russia. Putin was the highest-ranking Russian official who has ever commemorated the massacre of Katyn, and Tusk was the first Polish leader who has received an official invitation to participate in such ceremonies.

${ }^{321}$ As mentioned above, the 1 September and the $70^{\text {th }}$ anniversary of the beginning of Second World War I was recognized as significant shift in American attitude toward the Central European region. However, an even greater impact on Polish foreign policy conduct might have been the tragic Smoleńsk accident when Polish President Lech Kaczyński together with other Polish prominent figures (Poland's army chief, central bank governor, leading historians and others) were killed in a plane crash in Russia. According to Donald Tusk, this was the most tragic event of the Polish post-World War II history. This tragic event and later meetings between Polish and Russian officials gave hope for an important milestone in the emergence of a Polish - Russian memory culture, which could strengthen the process of historical reconciliation between these two countries. However, the later investigation process and unclear gambits during the final report of the investigation from 
with Russia, Poles learned that they can achieve much more through a less emotional and historically saturated foreign policy approach. As Nowak stated, "we found that we are less effective while we are considered in EU as the Cold War warrior against Russia, because for many EU members the relations with the Russia are pivotal". Achieving better relations with Russia posses also has an indirect impact on Polish-French relations, since Paris considers Moscow as an indispensable partner. 322

After a series of mutual gaffes and missteps, America's relations with Central and Eastern Europe needed their own 'reset button.' The US Vice President, Joe Biden, emphasized in his remarks in Bucharest that in contemporary worldwide conditions Washington looks for what it can do with EastCentral Europe, instead of what it can do for the states from this particular area of the world. ${ }^{323}$ However, it seems that Americans should slowly get used to the inevitable day when Poland and other Central European countries will oppose Washington's political, economic or military projects. And it will not be associated to Central European resentment towards Washington's foreign policy, but a sign of the times of independence and maturity of V4 countries in international politics. ${ }^{324}$ The image of Poland as a state willing to cooperate with major European countries improved its position within the EU and restored Polish dreams that the "Weimar Triangle" - composed of France, Germany and Poland - might be a powerful locomotive of growth and the Polish leadership position of the East-Central European region will be consolidated. The credibility of Poland within the EU was also strengthened when Warsaw successfully overcame the financial crisis of 2008/2009, and showed a positive growth even in 2011/2012 when many other European economies had been shaken in their foundations. ${ }^{325}$ The Polish government often tends to use a phrase that the country is a "green island" on the "red sea" of an economic crisis. ${ }^{326}$

the Russian side showed that Moscow is still not prepared to acknowledge its own mistakes, which hampers closer cooperation with Poland, See "Polish President Kaczyński Dies in Plane Crash", BBC News (10 April 2010); http://news.bbc.co.uk/2/hi/8612825.stm

${ }^{322}$ Jozwiak, EU's Largest New Member, Poland, Takes Over Presidency.

${ }^{323}$ Lightfoot, America's New Partnership with Central Europe.

${ }^{324}$ Pisarski, Polska Jest Cheerleaderem w Oczach Ameryki.

${ }^{325}$ According to European Commision's economic forecast the highest growth in 2011 will be in Lithuania (3.4 \%), Estonia (3.2\%) and in Poland and Latvia (2.5\%). The EC also estimated that economic growth in Poland in 2012 will be $4 \%$, while in all EU will be around of 1.6\% of GDP. See: PAP, (Prognozy KE: $+2,5$ proc. PKB w 2012. Lepsze tylko kraje nadbałtyckie) Gazeta.pl, 
Only 7 years has passed when Visegrad group member countries, together with other East-Central and outhern European states, joined the European Union. The majority of them were a "refugees" from the Soviet bloc and their accession was a fulfillment of all promises - seemed to be unrealistic in the 1990s - made by Western countries, that they could join Western political structures. After the accession of Bulgaria and Romania in January 2007, the EU enlarged to the current number of 27 states. The newcomers were perceived by Western capitals as a risky ground to cope with the common market issues. Many European notables wondered if they would respect the EU principles or interfere in future projects. But who could have predicted that in 2011 Brussels would be wondering about Greece, Portugal, Spain, Ireland and at the moment also about Italy, and that Poland during its Presidency within the EU will be presenting solutions to the current problems through an historical perspective and assure others that the European project has a bright future. ${ }^{327}$

Therefore, while the United States is changing its priorities to face the challenges of the XXI century, Visegrad member group countries will seek support in regional structures such as the European Union. The attitude of the Central European countries to the EU has become more and more positive - according to a recent survey, $83 \%$ of Poles said that joining the bloc was beneficial for the country. It is expected that during its 6-month presidency, Poland will promote its traditional agenda of integrating the countries beyond the eastern border of the EU, such as Ukraine and Georgia. Poland was one of the driving forces behind the EU's Eastern Partnership program and wishes to enter into an agreement with Ukraine on a deep and comprehensive free trade area (DCFTA). ${ }^{328}$ Even the faith of Central European countries that NATO will ensure security in the region seems to have moments of doubt. After all, Polish efforts for American military presence on its own territory, in fact is nothing else than a manifestation of lack of confidence in regard to guarantees contained in NATO's Article 5.329

http://gospodarka.gazeta.pl/gospodarka/1,33181,10622608,Prognozy_KE__2_5_proc_PKB_w_2012_Lepsz e_tylko_kraje.html

${ }^{326}$ Jozwiak, EU's Largest New Member, Poland, Takes Over Presidency.

327 Krzysztof Bobiński, „Poland's European Infusion”, Open Democracy (July 13, 2011), http://www.opendemocracy.net/krzysztof-bobinski/poland's-european-infusion

${ }^{328}$ Jozwiak, EU's Largest New Member, Poland, Takes Over Presidency.

${ }^{329}$ Pisarski, Polska Jest Cheerleaderem w Oczach Ameryki. 
According to Zbiniew Pisarski, for President Barack Obama and American politicians, Poland and other countries of Central and Eastern Europe are in the second league, treated less by the optics of bilateral relations and more by regional dimension. The positive factor of this dimension is that in this second league Poland is the leader of a table. ${ }^{330}$ Moreover, the metamorphosis of Warsaw into a cheerleader of Central and Eastern Europe allows Poland to present and cheer on others to act, pose for photos, but still remain outside the main arena of the global politics game. It's time to show to the world, which perfectly knows and takes advantage of Polish weaknesses for gestures, symbols and praise, a new Polish version of "realpolitik". ${ }^{331}$

\footnotetext{
${ }^{330}$ Ibid.

${ }^{331}$ Ibid.
} 


\section{Conclusions}

The $10^{\text {th }}$ anniversary of American intervention in Afghanistan became a perfect opportunity to undertake research linked to NATO's mission in Afghanistan. However, the adopted approach of this research differs considerably from the existing ones. As a resident of Poland - the largest Central European country - I found it interesting to undertake a project that directly addresses a large gap in the literature on the ISAF mission in Afghanistan, which is the Central European countries participation in the Afghan stabilization mission. In regard to the formulated goals of this study, the V4 countries' participation in the ISAF mission was examined within the international framework of this mission.

The end of the Cold War left NATO in a vacuum. The Alliance had to determine its position and new mission to legitimize its existence. To be up to challenge in the XXI century required appropriate remedies; thus NATO tried to undertake a concerted effort to respond to recognized challenges and provide solutions. Therefore the ISAF mission in Afghanistan became for large number of scholars the greatest contemporary challenge in NATO's existence. As the American Republican Senators said, NATO in the XXI century either had to go "out-of-area" or out of business. ${ }^{332}$ Indeed, as international forces have faced ever greater problems in Afghanistan, NATO's mission become acknowledged as a real test of its prestige and ability to conduct out-of-area military operations on a large scale, corresponding to the threat posed by a new type of asymmetric conflict.

The beginning of the operation had not brought worries to U.S. and NATO leaders. In the initial stage before and during the operation, when V4 countries' contribution was the smallest, Western strategists planned successful combat operations and short-term reconstruction and humanitarian efforts. There was a visible consensus among Western policy-makers that the purpose of Afghan intervention was to defeat Al-Qaeda militarily and to oust the Taliban regime, which had provided AlQaeda protection. Afghanistan was regarded by the American administration as a 'failed state', and ascribing such a definition to Afghanistan was equivalent to perceiving such conditions as the grounds for the existence a "safe haven" for terrorist organizations in the first place. As a result, the long-term aim of the stabilization mission was to clear the way for Afghanistan to become an economically self-sufficient, politically stable and reasonable state so as to change conditions for the future existence of terrorist organizations. Despite initial military success (or its delusion as has

\footnotetext{
${ }^{332}$ Chappel, What Future for, 5.
} 
already been discussed in the first chapter of the paper), international forces have from year to year increasingly encountered assaults by re-emerging Taliban armed groups. The problem was that the implementation of counterterrorist and reconstruction efforts into a coherent, common international strategy approach was contested. Coalition member states faced the problem of insufficient political support and coordination, which basically was the main obstacle to translating military success into a similarly successful reconstruction effort with the long-term goal of sustaining stability. ${ }^{333}$

Long before Barack Obama became a president of the United States, American and NATO leaders had been already aware that stabilization mission of Afghanistan would not be a quick and painless process and the military activities had to be followed by a long-term effort and supported by sufficient financial effort. They were also conscious that what was possible at the beginning now had become very difficult to achieve. The lack of troop strength during the Bush era was one of the major obstacles to accomplishing the mission in Afghanistan. Therefore, the burden-sharing complexity also affected alliance results, especially the commitment to NATO ISAF operation in Afghanistan. Jaap de Hoop Scheffer, NATO Secretary General 2004-2009, emphasized in January 2009 the need for allied countries "to step up, with more forces... It is fair, and I think politically healthy, if we have a fair balance of burdens in this mission between the Allies". Robert Gates, U.S. Secretary of Defense, also appealed to NATO members to fulfill their promises for more troops within ISAF in Afghanistan. He expressed his opinion to the Senate Armed Services Committee in early 2008, stressing that he had become frustrated when allies had not lived up to their pledges in the ISAF: "I worry a lot about the alliance evolving into a two-tiered alliance, in which you have some allies willing to fight and die to protect people's security, and others who are not" ${ }^{334}$ In response to the request of the United States and NATO, the international community has decided to increase its commitment to the ISAF mission. Given the recent, relatively large number of V4 countries' forces in comparison to older NATO members on the ground in Afghanistan, particularly given the tasks they face, the Afghan stabilization mission developed into a new challenge for Central European countries in the XXI century, and probably the most important and the most difficult mission for Central European armed forces. ${ }^{335}$

\footnotetext{
${ }^{333}$ Noetzel and Scheipers, Coalition Warfare, 2.

${ }^{334}$ Hillison, New NATO Members, 16-17.

${ }^{335}$ Noetzel and Scheipers, Coalition Warfare, 2.
} 
Visegrad group member countries - the Czech Republic, Hungary, Poland, Slovakia - chosen to be examined in this paper, in regard to NATO's mission in Afghanistan demonstrate all the hallmarks of treating it with the same level of importance. My analysis proves that it is in the interest of Central European countries to strengthen the Alliance and participate in the constant validation of its political and military credibility. The fundamental role of NATO in Central European countries' security results from basic strategic documents related to common defense. Therefore, to put it simply, the success of the operation will confirm the credibility and strengthen the cohesiveness of the Alliance. The failure of the NATO-led ISAF mission would weaken the Alliance, and de facto, one of the pillars of Central European security. ${ }^{336}$ However, in such complex missions as this one in Afghanistan, where the potential benefits are hard to articulate and when high domestic political costs exist, it would have been difficult for NATO to block the reasonable motives for a "free-ride" regarding the ISAF mission in Afghanistan. First, because of increased casualties and lower public support for the mission since the beginning of operation. Secondly, due to the complexity of the mission and the distance from Europe. It is hard to explain to public opinion how the mission is linked to a country's national interest. ${ }^{337}$

The findings of this paper have showed that although V4 countries' troop contribution lagged in the early phase of the ISAF mission, with the passing of time they have shared fairly the burden of responsibilities in Afghanistan. The initial level of contribution to NATO's mission in Afghanistan to some scholars might have been considered "free-riding" behavior however, the lack of commitment was constrained, especially in case of Poland, by involvement in the Iraqi mission. ${ }^{338}$ Moreover, V4 countries did not deploy forces to Afghanistan only because of allied obligations but also because of national interest and pragmatic reasons. Such considerable contributions by V4 countries come from their aspiration to authenticate their reputation as a reliable allies. Once a new alliance member achieves a reputation for meeting its commitments, it becomes easier for the country to intensify its level of coordination within NATO. In addition, the Afghanistan mission provides a valuable experience for the Central European armed forces in unaccommodating real combat conditions, command procedures and test of their military equipment, which enables them to increase their degree of modularity while gaining considerable experience in cooperation with international forces. This experience prepares Central European Armed Forces for the new challenges and threats to their

\footnotetext{
${ }^{336}$ Winid, Udział Polski w Działaniach Stabilizacyjnych, 10.

${ }^{337}$ Hillison, New NATO Members, 27.

${ }^{338}$ Ibid., 32.
} 
security in the region and from distant regions of the world. Moreover, participation in the ISAF mission demanded from V4 countries to upgrade and professionalize their own forces and adapt them to participation in new out-of-area missions - probably without participation in the NATO ISAF mission in Afghanistan (and Iraqi mission in the case of Poland) it would have consumed much more time. Therefore, active participation in the Afghanistan mission has boosted modernization processes in Central European armed forces, which they had not been able to introduce since their accession to NATO. Therefore, this phenomenon directly strengthens Central European armed forces defense and combat capabilities. ${ }^{339}$

Further, one of the interesting findings from this paper concerns the region's growing independence and the boost in confidence of the V4 countries' political establishment since NATO's enlargement of the end of XX century. It appears that V4 countries have also learned that possible threats might come not only from the East, but they have grown to understand the complexity of global security threats also from a sub-region of the world, which has to be linked the Central European area. As Janos Martonyi, Hungarian minister of foreign affairs, emphasized - collective security is the fundamental issue for the NATO member countries if they want to successfully face the challenges of the XXI century. ${ }^{340}$ However, between political circles and public opinion there exists a visible split over the advisability of sending Central European armed forces to distant Afghanistan. Therefore as the examined data in this thesis shows, citizens of Central Europe regularly raised the question of losses and profits from participation in the ISAF mission in Afghanistan.

The undertaken analysis shows that V4 member countries indeed had and have a deep desire to establish their reliability to the United States and their European allies. Prior to the 2004 EU enlargement, V4 countries were seeking membership in the EU. Straight after the accession they wanted to establish a better negotiating position within the EU political structures and meanwhile enhance their close relationship with the United States. For the V4 countries, a stronger position within the EU has a direct influence on their position in NATO, and vice versa. However, EU membership connotes economic prosperity and civilization advance, while NATO as has be emphasized, indicates better perspectives for security conditions in the region. Therefore, V4 countries' performance within the ISAF mission influences their position within NATO and future Alliance policy agenda in the XXI-century. Therefore V4 countries could not afford a free-riding

\footnotetext{
${ }^{339}$ Hołdak and Komarzewska. Afganistan, Irak, Czad - Co Mamy z Misji ?, 142-143.

${ }^{340}$ Budapest also agreed that is necessary to promote a better relationship with Russian Federation.
} 
performance which might seriously weaken their reliability and exclude them from NATO leaders' decision-making process. Not to mention that CEC's performance on Afghan soil has direct implications for their relations with the United States and the so-called special relationship between Washington and this particular area of the world. However, entering into the second decade of the XXI century, Poland and Central European countries started assessing the meetings through the prism of particular agreements and their final positive outcomes for the national interest. In the process it was determined that investment of troops and money did not translate into a change of relations with the USA in particularly sensitive areas, as expected by Central European governments

The new generation of Central European citizens and politicians do not seem to be anti-American, but there is a growing sense that V4 countries, especially Poland, went too far in supporting Washington's foreign policy. The major reason for the reassessment of the Polish - American relationship is Warsaw's heightened self-reliance as a member of the European Union, and awareness that now the most pivotal issues are negotiated in Brussels. Another explanation is that Warsaw is mindful that being one of the most devoted US allies in Europe has brought more disadvantages than advantages. Poland incensed its major European allies when it decided to take an active part in the 2003 invasion of Iraq, but the mission in and of itself - where the Poles were in command and responsible for a whole province - brought, in addition to military experience, several economic and diplomatic gains. ${ }^{341}$ Therefore at the end of 2007, Warsaw decided to withdraw Polish Armed Forces from Iraq by the end of October 2008. Central European countries also expected visible benefits from their participation in the ISAF mission in Afghanistan. One of the indirect benefits expected by Poland together with the Czech Republic was the missile defense system which was supposed to be located on their territories. However, when President Obama did not participate in the $70^{\text {th }}$ anniversary of the start of Second World War and uncovered his new agenda for the European missile defense system and abandoned the existing plan of predecessor, Central European countries took for granted that this decision had something to do with Russia and the United States had conceded to Moscow's demands.

However, the American shift in foreign policy approach has not resulted in the considerable improvement of relations between Washington and Moscow. According to Andrew Michta, the concerns of Central European countries that Moscow will become a partner of Washington were unfounded. In America, Russia is regarded as a difficult partner that hinders U.S. global politics;

\footnotetext{
${ }^{341}$ Cienski, The Decline of America and Poland's Special Relationship ; See more about Polish participation in the Iraqi mission in: Hołdak and Komarzewska. Afganistan, Irak, Czad - Co Mamy z Misji ?, 98-114.
} 
therefore they have to agree to procedures between themselves, but not at the expense of relations with Central European countries. The so called "reset" of American-Russian relations was a useful political step, and would not have brought so much fear, it had been done differently. The way how the American administration announced a shift in missile defense program was clumsy. Central European countries felt that the Americans are talking with Russia without consulting them. ${ }^{342}$

Since the collapse of the Soviet Union, Central European countries have learned a lot and undergone a successful transformation process. When President Obama prioritized its foreign policy activities and wanted to work with strong and capable partners, he found them in Central Europe. At present Central European countries are important members of the European Union and NATO and they do not require from Washington special treatment and nurturing projects directed at them. According to Jeffrey Lightfoot, an assistant director of the International Security Program at the Atlantic Council, the "normalization" of the relationship between the Washington and particular countries of Central-Eastern European countries, and the whole region as a whole, is a far-reaching heritage of double cadency in the Presidency of George W. Bush. Notwithstanding Bush's reputation across the European continent, his wide ranging agenda and focus on the countries of East-Central Europe strengthened their stature, increased their capabilities, and promoted them to more equal relationship status in Europe and within the transatlantic Alliance. ${ }^{343}$

However, the new Obama administration, certainly in the first phase, made missteps toward the Central European region. The V4 countries, and Poland, are especially sensitive to historical questions and Obama had to reassure the new NATO allies who have been betrayed too many times in their long history. The recent visit of Obama in Poland was aimed to wipe out his administration's mistakes toward faithful allies in East-Central Europe. Obama wanted to win over the Central European countries to the wider plan of American foreign policy approach by creating a network of institutions and capitals cooperating with the United States. Warsaw, and other East-Central European capitals, are seen as increasingly important players within the European Union. ${ }^{344}$ However, it seems that Americans should also slowly get used to the inevitable day when Poland and other Central European countries will oppose Washington's political, economic or military projects. And it will not be

\footnotetext{
${ }^{342}$ Wawrzyniec Smoczyński, „Rozmowa z Politologiem Andrew Michtą: Wiosłujcie z Nami”. Polityka.pl, 25 Maj 2011, http://www.polityka.pl/swiat/rozmowy/1516206,1,rozmowa-z-politologiem-andrew-michta.read

${ }^{343}$ Lightfoot, America's New Partnership with Central Europe.

${ }^{344}$ Smoczyński, Rozmowa z Politologiem Andrew Michtq.
} 
associated to Central European resentment towards Washington's foreign policy, but a sign of the times of independence and maturity of V4 countries in international politics. 


\section{Bibliography}

Chappel, Garreth. What Future for 'Out-Of-Area' Operations after Afghanistan ? (Warsaw: The Polish Institute of International Affairs, Policy Paper, no. 4, March 2011).

Chollet, Derek., James Goldgeier. America Between the Wars. From 11/9 to 9/11. The Misunderstood Years Between the Fall of the Berlin Wall and the Start of the War on Terror. (New York: Public Affairs, 2008).

Dorronsoro, Gilles. Focus and Exit: An Alternative Strategy for the Afghan War (Washington D.C.: Carnegie Endowment for International Peace, January 2009).

Credible Deterrence for NATO in the XXI Century. Report from the Experts Roundtable. (Warsaw: Arms Control Association, British American Security Information Council, Institute for Peace Research and Security Policy Hamburg, Polish Institute of International Affairs with Support of William and Flora Hewlett Foundation, 5-6 July 2010).

Exum, Andrew. Leverage: Designing a Political Campaign for Afghanistan. (Washington, D.C.: Center for a New American Security, May 2010).

Górka-Winter, Beata and Marek Madej. Nato Member States and the New Strategic Concept: An Overview. (Warsaw: The Polish Institute of Foreign Affairs, May 2010).

Hillison, John R. New NATO Members: Security Consumers or Producers ? (United States: Strategic Studies Institute, United States Army War College, 22 April 2009).

Hofbauer, Joachim and Roy Levy, Gregory Sanders, Matthew Zlatnik. European Defense Trends. Budgets, Regulatory Frameworks, and the Industrial Base (Washington: Center for Strategic and International Studies, Defense-Industrial Initiatives Group, May 2010).

Hołdak Katarzyna, Anna Komarzewska. Afganistan, Irak, Czad - Co Mamy z Misji ? Bilans Zysków i Strat. Perspektywy. (Warszawa: Biuro Bezpieczeństwa Narodowego, Bezpieczeństwo Narodowe, III,2008/7-8).

Kamiński, Antoni Z., ed. Polityka Bez Strategii. Bezpieczeństwo Europy Środkowo-Wschodniej i Polski w Perspektywie Ładu Globalnego. (Warszawa: Instytut Studiów Politycznych Polskiej Akademii Nauk, 2008).

Kiss, Laszlo J. Central Europe: 'Imagined Spaces' and Challenges of the $21^{\text {st }}$ Century. (Foreign Policy Review, Vol. 7, 2010).

Korski, Daniel. Shaping Europe's Afghan Surge. (London: European Council on Foreign Relations, Policy Brief, March 2009). 
Kuźniar, Roman. Polityka i Siła. Studia Strategiczne - Zarys Problematyki. (Warszawa: Wydawnictwo Naukowe Scholar, 2005).

Lord, Kristin M. and Marc Lynch. America's Extended Hand. Assessing the Obama Administration's Global Engagement Strategy. (Washington, D.C.: Center for a New American Security, June 2010).

Lynch, Mark. Rhetoric and Reality. Countering Terrorism in the Age of Obama. (Washington, D.C.: Center for a New American Security, June 2010).

Mastriano, Douglas V. Faust and the Padshah Sphinx: Reshaping the NATO Alliance to Win in Afghanistan. (Carlisle Barracks: US Army War College, 2010).

McCormick, James M. American Foreign Policy and Process. Fourth Edition. (Iowa State University: Thomson Wadsworth, 2005).

Mead, Walter, Russell. Special Providence: American Foreign Policy and How it Changed the World. (New York: Routledge, 2002).

Morelli, Vincent and Paul Belkin. NATO in Afghanistan: A Test of the Transatlantic Alliance. (Washington: Congressional Research Institute, 3 December 2009).

Noetzel, Timo and Scheipers, Sibylle. Coalition Warfare in Afghanistan: Burden-sharing or Disunity ? (London: Chatham House, The Royal Institute of International Affairs, October 2007).

Owens, Mackubin T. The Bush Doctrine: The Foreign Policy of Republican Empire. (Foreign Policy Research Institute, Winter 2009).

Peterson, James W. and Terry Hallmark. The New NATO Members and the Mission in Afghanistan: Political and Economic Risks. (New Orleans: Paper Prepared for delivery at the Annual Meeting of the Southern Political Science Associations, 11 January 2008).

Rotfeld, Adam Daniel ed. NATO 2020. Zapewnione Bezpieczeństwo, Dynamiczne Zaangażowanie. (Warszawa: Polski Instytut Spraw Międzynarodowych, 2010).

Sanger, E. David. The Inheritance. The World Obama Confronts and the Challenges to American Power. (New York: Harmony Books, 2009).

Singh, Robert. "The Bush Doctrine," in, The Bush Doctrine and the War on Terrorism: Global Responses, Global Consequences. Mary, Buckley., Robert, Singh., editors. (London, New York: Routledge, 2006), 12-32. 
Światowa Opinia Publiczna o Polityce Stanów Zjednoczonych i Operacji NATO w Afganistanie. (Warszawa: Centrum Badania Opinii Społecznej, lipiec 2009).

Tokarski, Jan. 'Zmiana' bez zmiany (Warszawa: Centrum Europejskie Natolin. Analizy Natolińskie, 9 (32) 2008).

Transatlantic Trends 2009: Kluczowe wyniki 2009. (German Marshall Fund of the United States, 2009).

Transatlantic Trends 2011: Raport 2011. (German Marshall Fund of the United States, 2011).

Trzpil, Magdalena. Afganistan jako Największe Wspótczesne Wyzwanie dla NATO. (Warszawa: Biuro Bezpieczeństwa Narodowego, Bezpieczeństwo Narodowe, III-2009/11).

"We Are a Country Awakened to Danger and Called to Defend Freedom", The Text of President George W. Bush's Address to a Joint Session of Congress Concerning the Sept. 11, 2001 Terrorists Attacks on America, (The Archives of Global Change in the $21^{\text {st }}$ Century) http://www.september11news.com/PresidentBushSpeech.htm

Winid, Bogusław. Udział Polski w Działaniach Stabilizacyjnych. (Warszawa: Polski Instytut Spraw Międzynarodowych, Polski Przegląd Dyplomatyczny, nr 1 (35), 15 stycznia 2007).

\section{Internet Articles:}

Banusewicz, John D. "Lynn Thanks Czech Republic for Afghan Help". Prague: U.S. Department of Defense, American Forces Press Service, June 15, 2011. http://www.defense.gov/news/newsarticle.aspx?id=64333

Baranowski, Michał. „Polacy Nie Chcą Wybierać Między Ameryką a Europą”. Rzeczpospolita, 14.09.2011， http://www.rp.pl/artykul/9157,717188-Euroentuzjazm-i-sympatia-do-USA---GermanMarshall-Fund-.html

Bobiński, Krzysztof. „Poland's European Infusion”. Open Democracy, July 13, 2011, http://www.opendemocracy.net/krzysztof-bobinski/poland's-european-infusion

Cienski, Jan. "The Decline of America and Poland's Special Relationship". Warsaw: Global Post, September 10, 2009, http://www.globalpost.com/dispatch/poland/090909/poland-usa-foreignpolicy

Conley, Heather A. "President Obama's Return to Prague: An Opportunity to Reset". Center for Strategic and International Studies, April 5, 2010, http://csis.org/publication/president-obama'sreturn-prague-opportunity-reset 
Day, Matthew. "Czech Troops' Abandoned British Soldiers' in Afghanistan". Warsaw: The Telegraph, April

2009,

http://www.telegraph.co.uk/news/worldnews/europe/czechrepublic/5200990/Czech-troops-

abandoned-British-soldiers-in-Afghanistan.html

Gaz, lew, PAP. Prognozy KE: $+2,5$ proc. „PKB w 2012. Lepsze tylko kraje nadbałtyckie”. Warszawa: Gazeta.pl,

http://gospodarka.gazeta.pl/gospodarka/1,33181,10622608,Prognozy_KE__2_5_proc_PKB_w_201 2_Lepsze_tylko_kraje.html

GW. "An Open Letter to the Obama Administration from Central and Eastern Europe". Gazetawyborcza.pl,

15.07.2009,

http://wyborcza.pl/1,76842,6825987,An_Open_Letter_to_the_Obama_Administration_from_Centra I.html

Isherwood, Julian. "Denmark Tops Afghan per Capita KIA Figures". Copenhagen: Politiken, 16 February 2009, http://politiken.dk/newsinenglish/ECE650209/denmark-tops-afghan-per-capita-kiafigures/

Lightfoot, Jeff. "America's New Partnership with Central Europe". Washington D.C.: Atlantic Council, November 6, 2009, http://www.acus.org/new_atlanticist/americas-new-partnership-central-europe

Jozwiak, Rikard. "EU's Largest New Member, Poland, Takes Over Presidency". Brussels/Warsaw: Radio Free Europe, June 30, 2011, http://www.rferl.org/content/eu_largest_new_member_poland_takes_over_presidency/24251314. html

Machnikowski, Ryszard. "Globalny Terroryzm a Sprawa Polska”. Warszawa: Stosunki Międzynarodowe, 11 Września 2011, http://www.stosunki.pl/?q=content/globalny-terroryzmsprawa-polska

Motlagh, Jason. "For U.S. Troops in Afghanistan, Coalition Forces Are Mixed Blessing". Ghazni: Time World, December 08, 2010. http://www.time.com/time/world/article/0,8599,2035859,00.html

PAP. „Dowódca ISAF: 'Polscy Żołnierze Imponują Odwagą”. Wirtualna Polska. 20.12. 2010, http://konflikty.wp.pl/kat,1020347,title,Dowodca-ISAF-polscy-zolnierze-imponujaodwaga,wid,12963184,wiadomosc.html

PAP. "Ile Kosztuje polaków Wojna w Afganistanie?" Wirtualna Polska, 23.12.2010, http://konflikty.wp.pl/kat,1020347,title,Ile-kosztuje-Polakow-wojna-w-

Afganistanie,wid,12976680, wiadomosc.html

PAP. "Time' Krytykuje Polskich Żołnierzy - NATO ich chwali”. Wirtualna Polska, 21.12.2010, http://konflikty.wp.pl/kat,1356,title,Time-krytykuje-polskich-zolnierzy-NATO-ichchwali,wid,12967721, wiadomosc.html 
Pisarski, Zbigniew. „Polska Jest Cheerleaderem w Oczach Ameryki - Czas na Real Politik”, Stosunki Międzynarodowe,

05.06.2011, http://www.stosunkimiedzynarodowe.info/artykul,1018,Polska_jest_cheerleaderem_w_oczach_Am eryki_?_czas_na_realpolitik

"Polish President Kaczyński Dies in Plane Crash". BBC News, 10 April 2010, http://news.bbc.co.uk/2/hi/8612825.stm

Pothier, Fabrice. "Europe: Loosing and at a Loss ?" Brussels: Carnegie Endowment for International Peace, Op-Eds, Articles, November 9, 2009, http://carnegieeurope.eu/publications/?fa=24115

Radu, Michael. "Old Europe vs. New". Philadelphia: Foreign Policy Research Institute, E-notes, March 12, 2003, http://www.fpri.org/enotes/20030312.radu.oldeuropevsnew.html

Smoczyński, Wawrzyniec. „Rozmowa z Politologiem Andrew Michtą: Wiosłujcie z Nami”. Polityka.pl, 25 Maj 2011, http://www.polityka.pl/swiat/rozmowy/1516206,1,rozmowa-z-politologiem-andrewmichta.read

Szabo Bela. "Increasing Role". Hungarian Defense, January 18, 2011, http://www.hungariandefence.com/cikk/23875/increasing-role

Wagner, Peter. "The Background of the Hungarian Activities in Baghlan". Hungarian Institute of Foreign Affairs, Policy Brief, February 15, 2010, http://www.kulugyiintezet.hu/pub/displ.asp?id=NBWWAE

WBS. „Polacy Przeciw Misji w Afganistanie”. Warszawa: Gazeta Wyborcza.pl, 01.12.2010, http://wyborcza.pl/1,76842,8746447,Polacy_przeciw_misji_w_Afganistanie.html

Zawadzki, Mariusz. „Początek Końca Wojny”. Waszyngton: Gazeta Wyborcza.pl, 23.06.2011, http://wyborcza.pl/1,112353,9831394,Poczatek_konca_wojny.html

\section{Additional Sources: Internet Websites}

Afganistan Conflict Monitor, Human Security Report Project -

http://www.conflictmonitors.org/countries/afghanistan/daily-briefing/

Afghanistan International Security Assistance Force Website - http://www.isaf.nato.int/

Central Intelligence Agency Website - The World Factbook https://www.cia.gov/library/publications/the-world-factbook/

Embassy of the United States Bratislava: Slovakia - http://slovakia.usembassy.gov/

Ministry of Defense \& Armed Forces of the Czech Republic Website - http://www.army.cz/en/ 
Ministry of Defense of the Slovak Republic Website - http://www.mod.gov.sk/

Ministry of Hungarian Foreign Affairs Website - http://www.mfa.gov.hu/kum/en/bal

Polish Military Contingent in Afghanistan Website - http://www.isaf.wp.mil.pl/pl/15.html

Visegrad Group Website - http://www.visegrad.info/

United States Central Command Website - http://www.centcom.mil/

U.S. Department of Defense Website -http://www.defense.gov/

Human Security Report Project: Afghanistan Conflict Monitor - http://www.conflictmonitors.org/ 